INTERNATIONAL MONETARY FUND

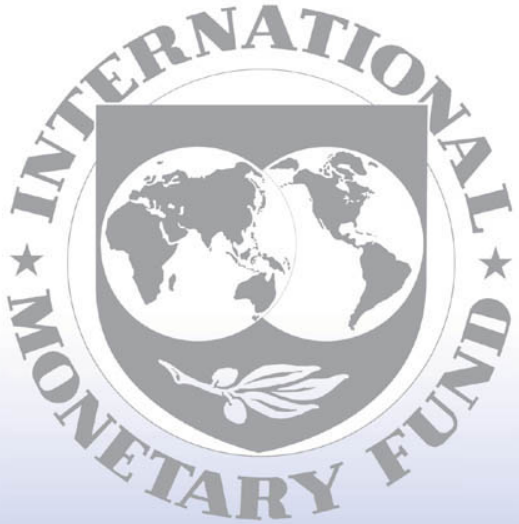

Staff

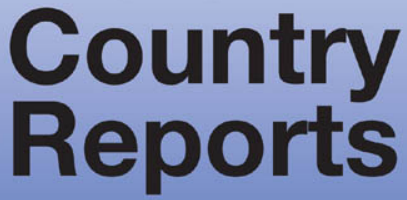




\title{
Spain: 2008 Article IV Consultation-Staff Report; Staff Supplement; Public Information Notice on the Executive Board Discussion
}

Under Article IV of the IMF's Articles of Agreement, the IMF holds bilateral discussions with members, usually every year. In the context of the 2008 Article IV consultation with Spain, the following documents have been released and are included in this package:

- The staff report for the 2008 Article IV consultation, prepared by a staff team of the IMF, following discussions that ended on December 9, 2008, with the officials of Spain on economic developments and policies. Based on information available at the time of these discussions, the staff report was completed on February 3, 2009. The views expressed in the staff report are those of the staff team and do not necessarily reflect the views of the Executive Board of the IMF.

- $\quad$ A staff supplement of March 6, 2009, updating information on recent developments.

- $\quad$ A Public Information Notice (PIN) summarizing the views of the Executive Board as expressed during its March 11, 2009 discussion of the staff report that concluded the Article IV consultation.

The document listed below has been or will be separately released.

\section{Selected Issues Paper}

The policy of publication of staff reports and other documents allows for the deletion of market-sensitive information.

\author{
Copies of this report are available to the public from \\ International Monetary Fund • Publication Services \\ $70019^{\text {th }}$ Street, N.W. • Washington, D.C. 20431 \\ Telephone: (202) 623-7430 • Telefax: (202) 623-7201 \\ E-mail: publications@imf.org •Internet: http://www.imf.org
}

\section{International Monetary Fund Washington, D.C.}


This page intentionally left blank 
INTERNATIONAL MONETARY FUND

\section{Spain-Staff Report for the 2008 Article IV Consultation}

Prepared by the European Department

(In consultation with other departments)

Approved by Ajai Chopra and Martin Mühleisen

February 3, 2009

\section{EXECUTIVE SUMMARY}

Background: Spain has entered a sharp downturn in the wake of the drying up of funding for the housing boom and large external deficit. Inflation is falling but remains structurally above the euro average. Labor markets are adjusting with labor shedding. Banks have weathered well the first impact of tighter funding conditions and weaker asset quality owing to strong prudential cushions. The fiscal deficit is ballooning, reflecting discretionary measures and a drop in important tax bases, including housing.

Challenges: The economy needs to shift from housing-led growth to a new model with stronger productivity and competitiveness. Consolidation in the banking system is likely. Fiscal policy needs to cushion the downturn while guarding sustainability.

Staff views: The large fiscal effort is helping to offset the drop in private demand. At the same time, measures should focus not just on demand, but facilitate substantial structural reform in labor and product markets as well, to boost supply and improve competitiveness. Further, to strengthen confidence, plans to achieve fiscal sustainability need to be spelled out. Prudential banking policies and credibility are strong, but contingency plans are required to augment bank capital if systemic pressures arise.

Authorities' views: The fiscal effort is commensurate with the size of the downturn. If the recession worsens, more assistance may be needed. The banking system needs support with funding, but does not need, at this stage, more capital. Lower unit labor costs are pursued through increased productivity and better jobs matching, not through wage moderation given lower average wages than in EU partners. Product and service market reforms are underway as agreed with EU partner countries. 
Executive Summary $\underline{1}$

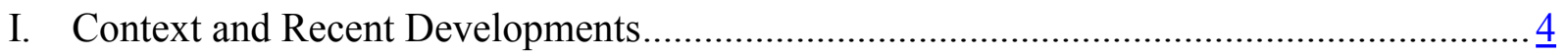

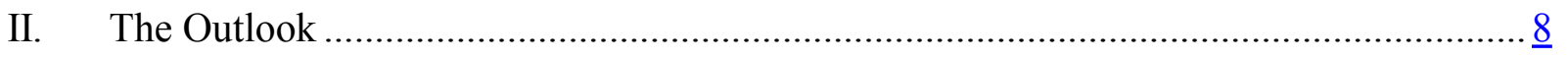

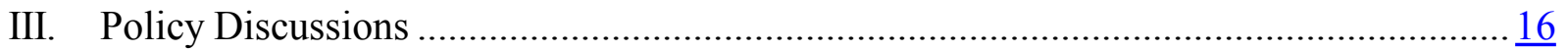

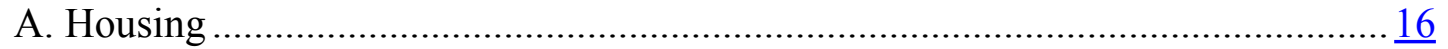

B. The Banking Sector ................................................................................ $\frac{19}{2}$

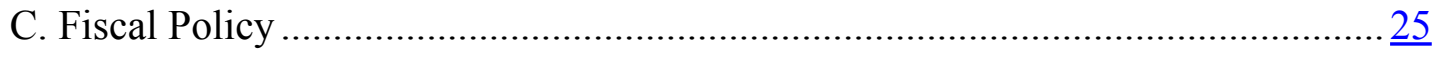

D. Competitiveness and Structural Reforms....................................................

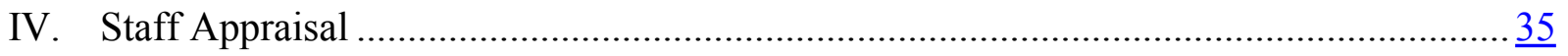

Boxes

1. The Spanish Prudential Framework ................................................................. 22

2. Bank Support Measures ............................................................................... 23

Figures

1. International Comparison..................................................................................... $\underline{5}$

2. Cyclical Indicators Suggest a Sharp Slowdown....................................................... $\underline{6}$

3. Labor Market Indicators Show that Unemployment Remains a Key Vulnerability .......... 1

4. Confidence Indicators ...............................................................................

5. Quarterly National Accounts Reveal the Expenditure Switch from Domestic

Demand Toward Next Exports ............................................................... 10

6. Balance of Payments and International Investment Position .................................... 11

7. Inflation and Wages .................................................................................... $\frac{12}{13}$

8. Fiscal Indicators Suggest There are Risks Ahead ................................................... $\frac{13}{17}$

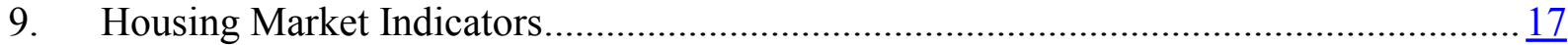

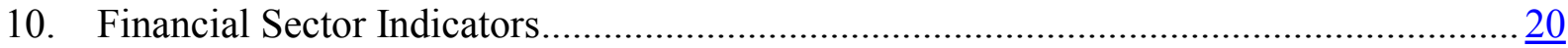

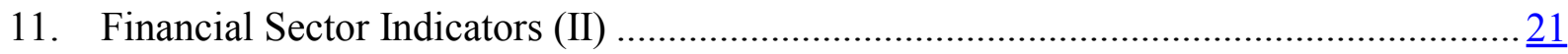

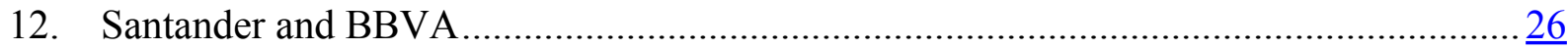

13. Demographic Indicators and Assumptions ......................................................... 29

14. Long-Run Macroeconomic Scenario and Public Debt Sustainability........................... $\frac{31}{33}$

15. Competitiveness Indicators .............................................................................. $\frac{33}{34}$

16. Labor Market Issues ..................................................................................... $\frac{34}{36}$

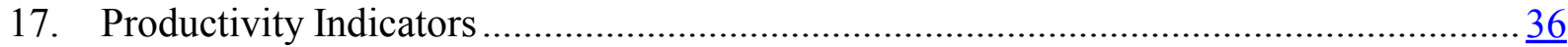

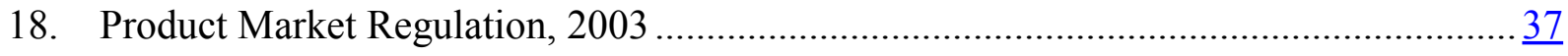

Tables

1. Main Economic Indicators ......................................................................... 40

2. Selected Financial Soundness Indicators...................................................... 41

3. Financial Soundness Indicators of the Non-Banking Sectors..................................... 42

4. Status of Implementation of Main FSAP Recommendations.................................... 43 
5. General Government Operations ....................................................................... 44

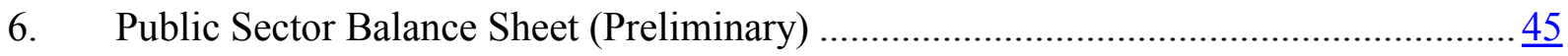

7. Balance of Payments …………………………............................................... 46

8. International Investment Position ........................................................................

Annex

I. External Debt Sustainability Framework ………………………………………...... 48 


\section{ConteXt And Recent Developments}

1. Spain was a growth leader for nearly 15 years until 2008.

Contributing factors were peseta devaluations in the early 1990s, EU integration, euro adoption, swelling immigration, rising incomes, and easy funding that permitted a housing boom.
Macroeconomic Indicators (average 1993-2007)

(Percent, unless otherwise indicated)

\begin{tabular}{lrr}
\hline & Spain & Euro area 1/ \\
\hline Per-Capita GDP growth & 2.2 & 1.7 \\
CPI inflation & 3.3 & 2.2 \\
Unemployment rate & 15.4 & 8.4 \\
CA deficit (percent of GDP) & -3.6 & 0.3 \\
\hline
\end{tabular}

Source: WEO.

1/ Excluding Spain.

2. Sustainability weakened as growth became increasingly dependent on importing labor and capital. Inflation exceeded the euro average. Productivity growth weakened as structural reforms lagged during the upswing. The expansion centered on nontradables. Households and companies became highly indebted. The current account deficit reached 10 percent of GDP by 2007 (Figure 1). With consistently negative external balances, the international investment position (IIP) steadily weakened. ${ }^{1}$

\section{What started as a soft landing turned into an abrupt unwinding of imbalances} with the global liquidity squeeze in mid-2007, posing a major macroeconomic challenge. Following a gradual slowing in activity beginning in 2006, the financial crisis has reduced funding for the external deficit and triggered a major bust in the housing market. With construction activity collapsing, banks under pressure, foreign demand faltering, and competitiveness weak, the economy now needs both cyclical support and deep structural reform. The authorities' challenge is to achieve this adjustment, and bolster competitiveness to avoid getting stuck in a long stagnation, while guarding fiscal sustainability.

4. The Socialist Party won reelection for a second term in March 2008. To address the crisis, the government has opted for increasing fiscal spending, assisting bank funding, initiating product market reforms, and improving job matching and active labor market policies. The main opposition conservative party would prefer tax cuts and increased financing for small and medium-sized companies. Both parties focus on short-term stabilization without an overarching intertemporal strategy.

$* * *$

5. At end-2008, as the global economic downturn accelerated, downside risks accumulated. Monthly indicators turned worse than expected with housing, industrial activity, and durable goods (vehicle sales) bearing the brunt of adjustment. Unemployment is rising fast, reaching 12.3 percent in November (Eurostat; Figures 2, 3). Bank funding tightened up

\footnotetext{
${ }^{1}$ The IIP is expected to weaken further as suggested by Annex I on the external debt sustainability analysis.
} 
Figure 1. Spain: International Comparison
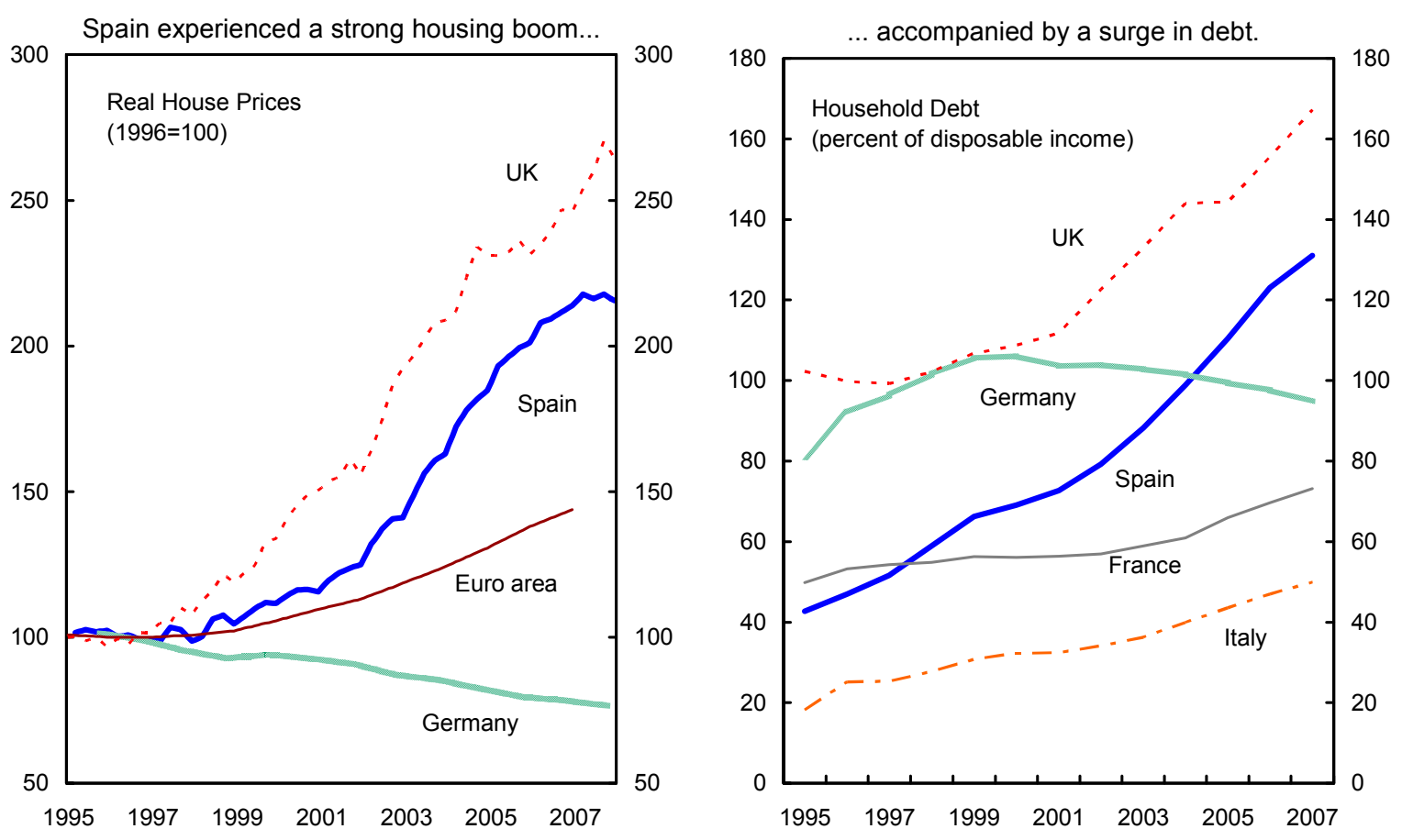

The current accout balance steadily deteriorated...
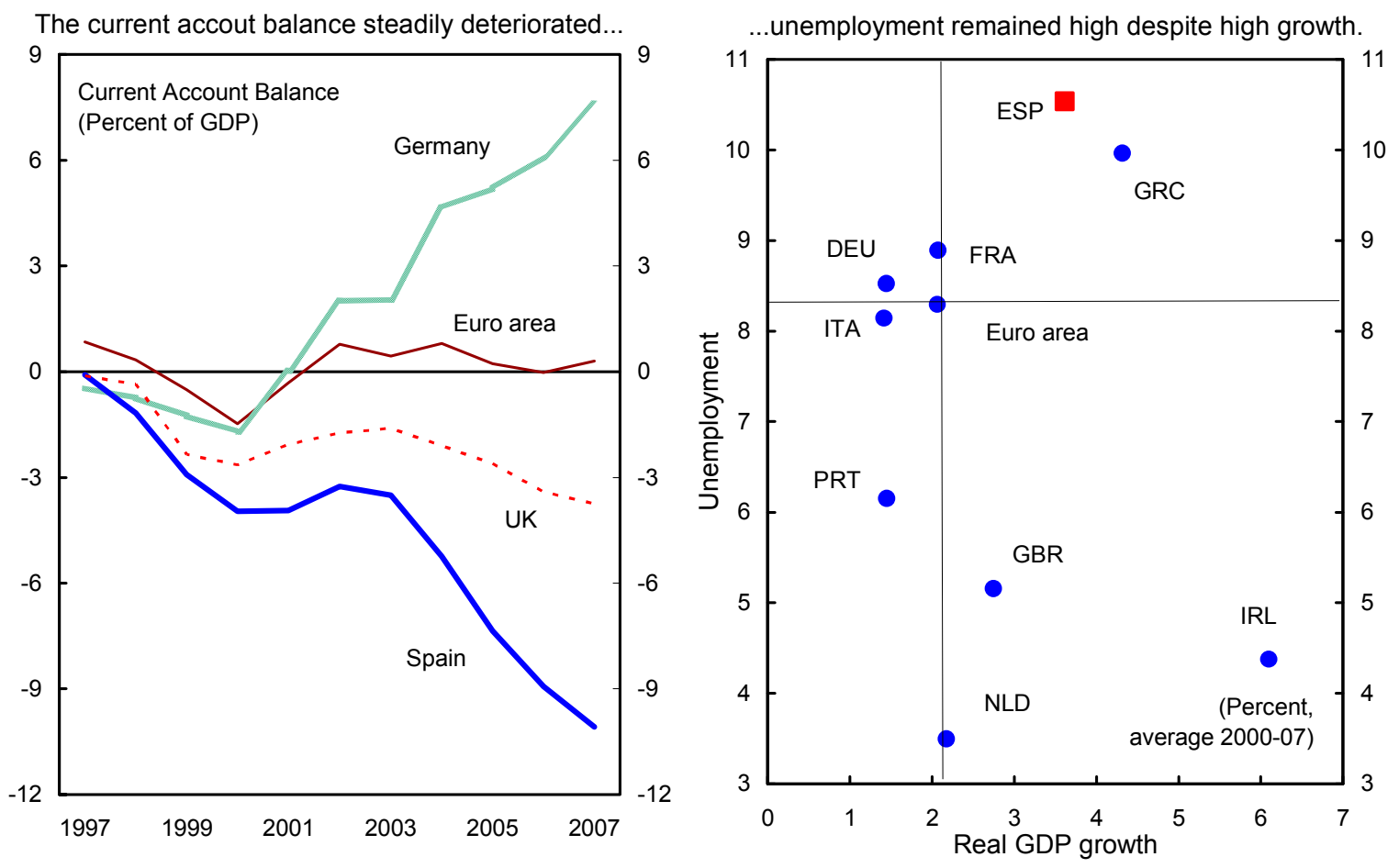

Sources: WEO; Bank of Spain; Eurostat; and IMF staff calculations. 
Figure 2. Spain--Cyclical Indicators Suggest a Sharp Slowdown (Year-on-year percent change, unless otherwise indicated)
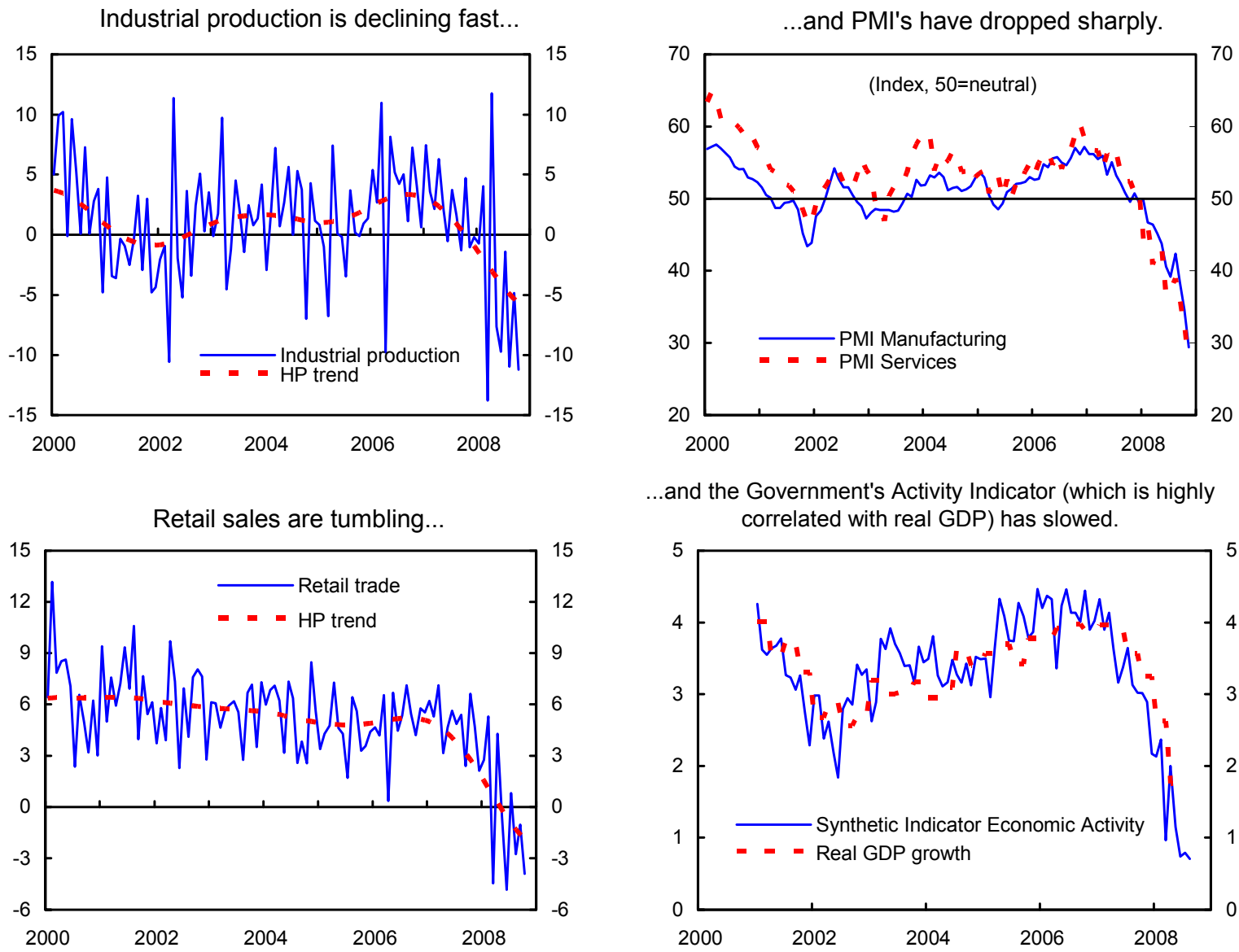

...and the Government's Activity Indicator (which is highly correlated with real GDP) has slowed.

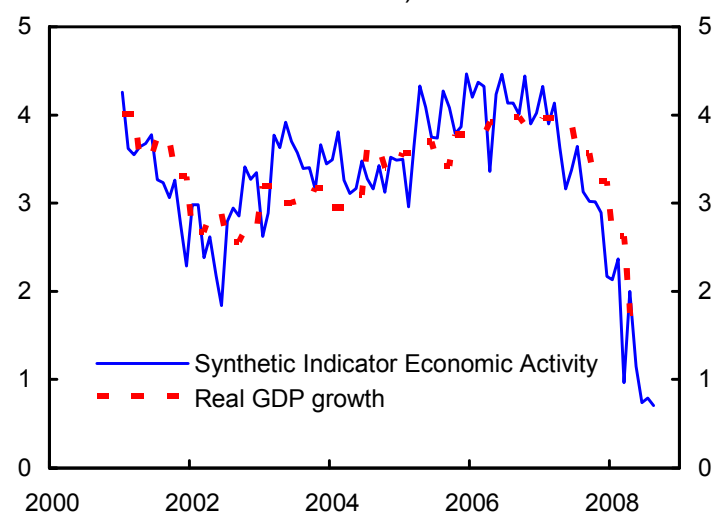

Housing Starts are down by 50 percent $y / y \ldots$
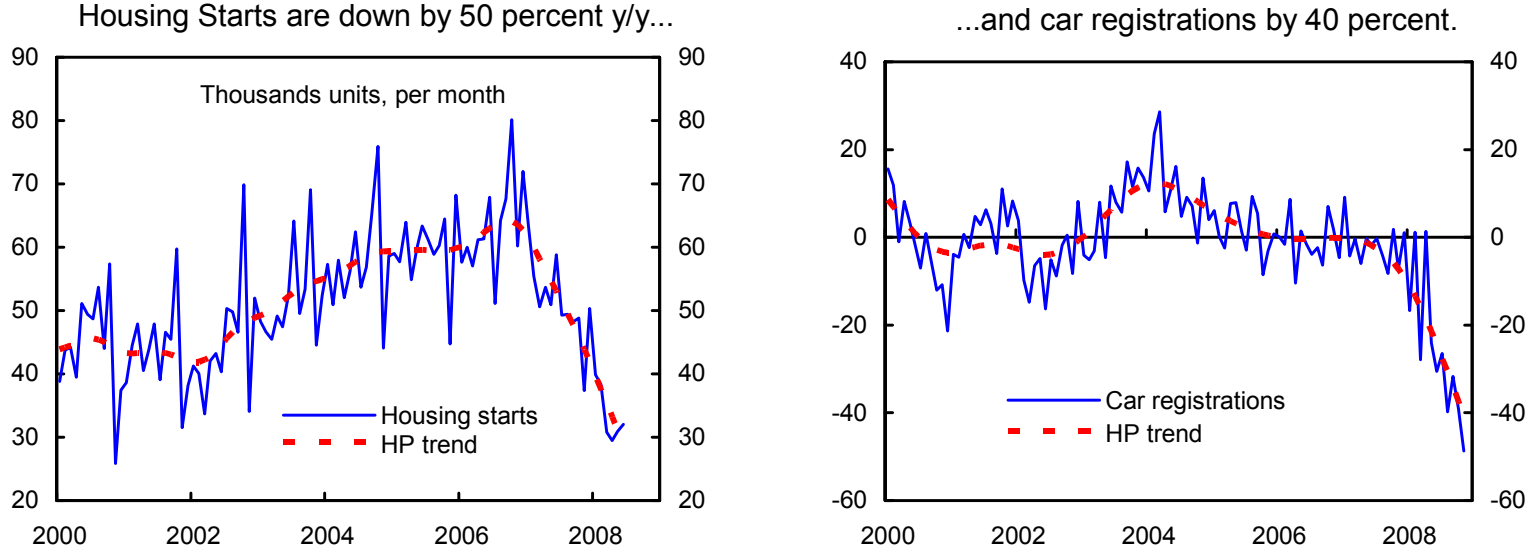

Source: IMF staff calculations based on data provided by the authorities. 
Figure 3. Spain--Labor Market Indicators Show that Unemployment Remains a Key Vulnerability (Year-on-year percent change, unless otherwise indicated)
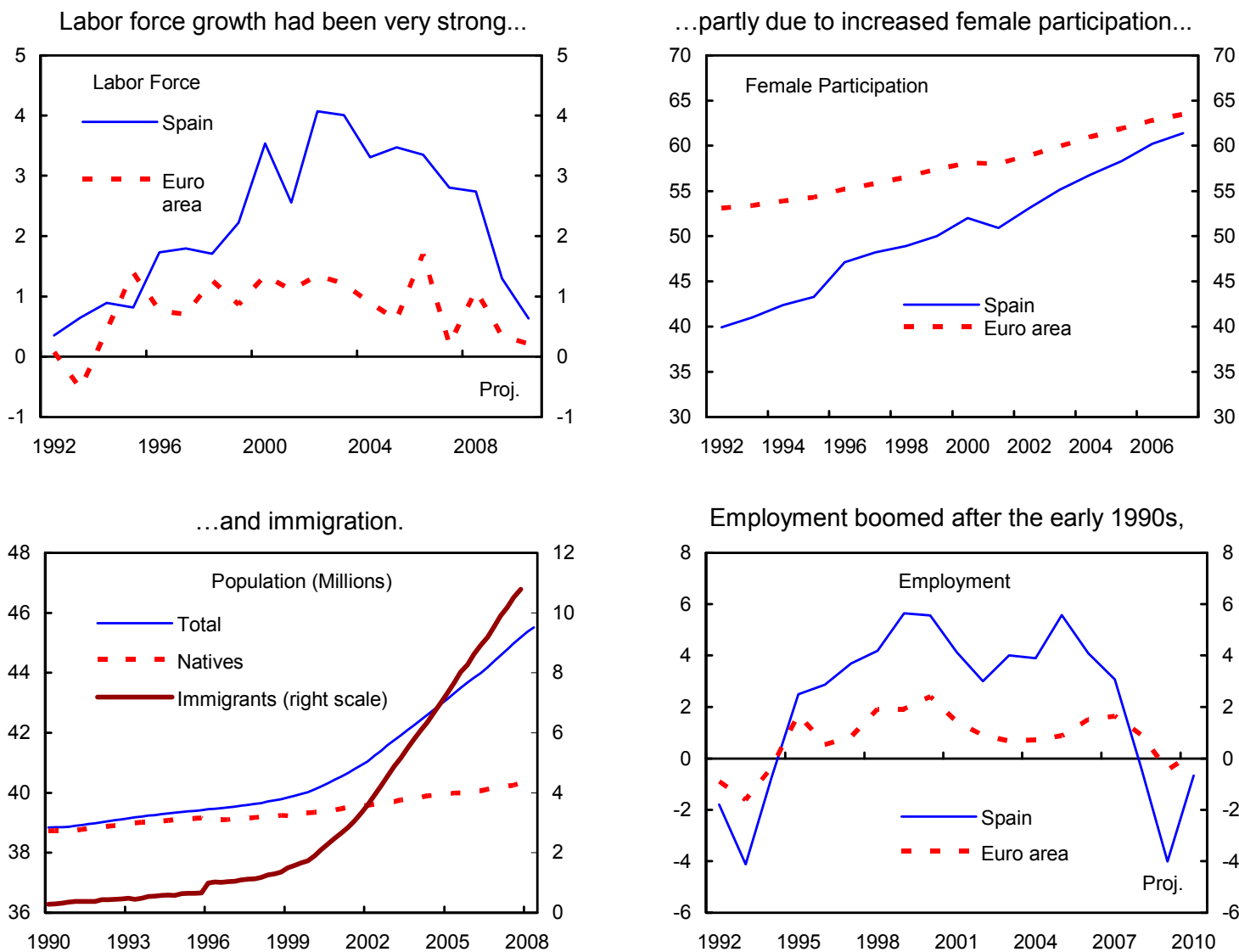

Employment boomed after the early 1990s,

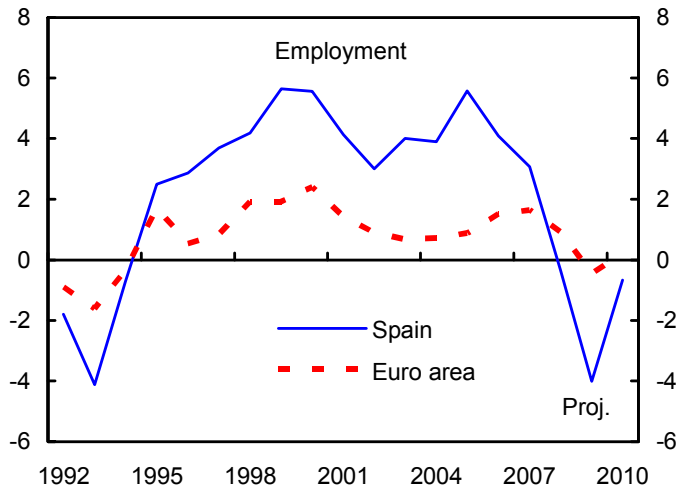

...however, unemployment remains high...

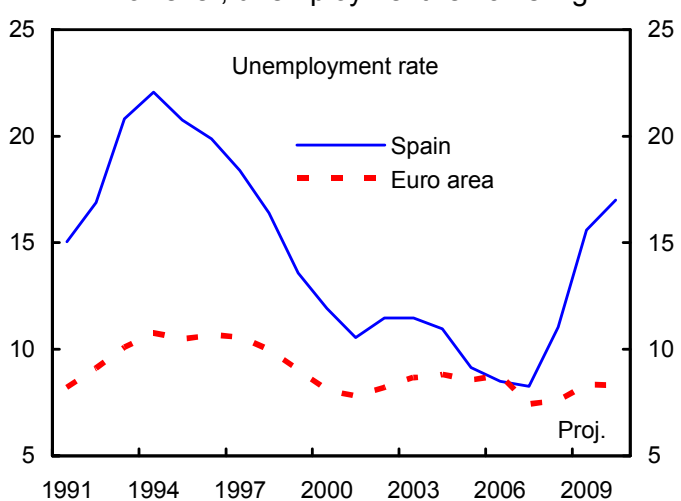

...even as hours worked per person are easing.

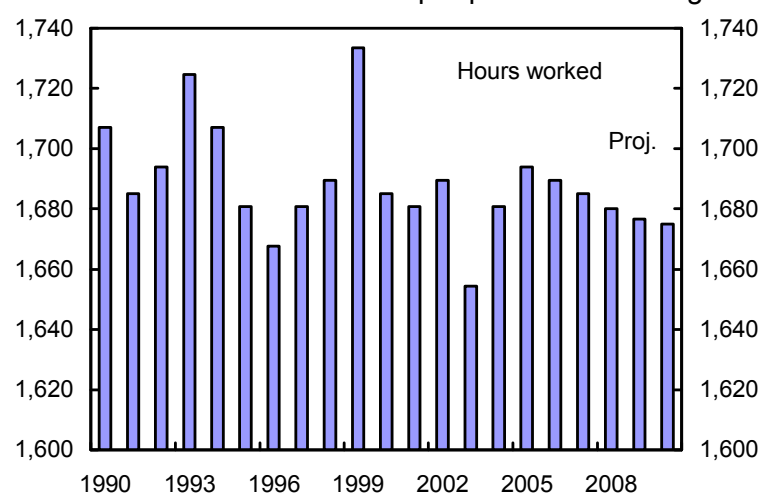

Sources: INE; WEO; and IMF staff calculations based on data provided by the authorities. 
again after the collapse of Lehman Brothers and continued losses in some large European banks. Many economies, including Spain, are deleveraging, with fiscal balances weakening as governments seek to soften the downturn.

6. A combination of slumping credit demand and tightening bank lending is slowing consumption and investment. With 98 percent of mortgages indexed to the 12-month euribor debt servicing costs first increased after the onset of the crisis in mid-2007, before easing sharply in late 2008. The spike in food and energy inflation further sapped disposable incomes and confidence. Construction investment slumped and machinery and equipment outlays fell with the weakening sales outlook (Figures 4, 5).

7. Spain's external current account deficit has started to improve. The process so far has been led by falling imports as domestic demand contracts. Net factor payments continue to worsen with the lower IIP (Figure 6).

8. Despite the slowdown, wage increases have outpaced the euro average, while headline inflation converged from above to the euro average in December 2008. Spain's high energy intensity made the oil shock especially painful. Indexation transferred price shocks to wages. Collective bargaining wages were rising at $3 \frac{1}{2}$ percent, but many contracts then added retroactive compensation when prices rose above a limit. Hourly labor cost growth is approaching 6 percent, compared with $3 \frac{1}{2}$ percent for the euro area as a whole (Figure 7). Weakly contested output markets, segmented labor markets, and low productivity raise costs and lower competitiveness. Inflation is now declining sharply with the drop in oil prices and indexation is expected to be less onerous in 2009.

9. The housing downturn, growing unemployment, and funding tightness have put banks under pressure. Asset quality is weakening as building companies are failing, house prices are declining, and unemployment is rising. Banks have used prudential cushions to absorb shocks, but lower asset returns and higher funding costs are beginning to reduce profitability. With banks, nonfinancial companies, and households all deleveraging, credit growth has slowed sharply from 25 percent $y / y$ in early 2007 to 7 percent in late 2008 .

\section{The general government balance has switched from moderate surpluses to} sizeable deficits. The soft economy slowed revenue, while spending outpaced output. The interest bonus from EU integration, lowering costs by over 3 percent of GDP, is no longer helping. The debt ratio has bottomed out. The central government is relatively small with subnational governments accounting for $2 / 3 \mathrm{~s}$ of spending. Social security accounts have a current surplus but actuarial deficit (Figure 8).

\section{THE OUTLOOK}

11. There was agreement that the outlook is somber. However, while deleveraging and global economic events exert downward pressure on growth, there were also upside developments. These include the recent sharp drop in oil prices and euribor rates, and the 
Figure 4. Spain--Confidence Indicators (Percent Balance, seasonally adjusted)

Consumer confidence has dropped sharply to well below that in EU-15 partner countries.

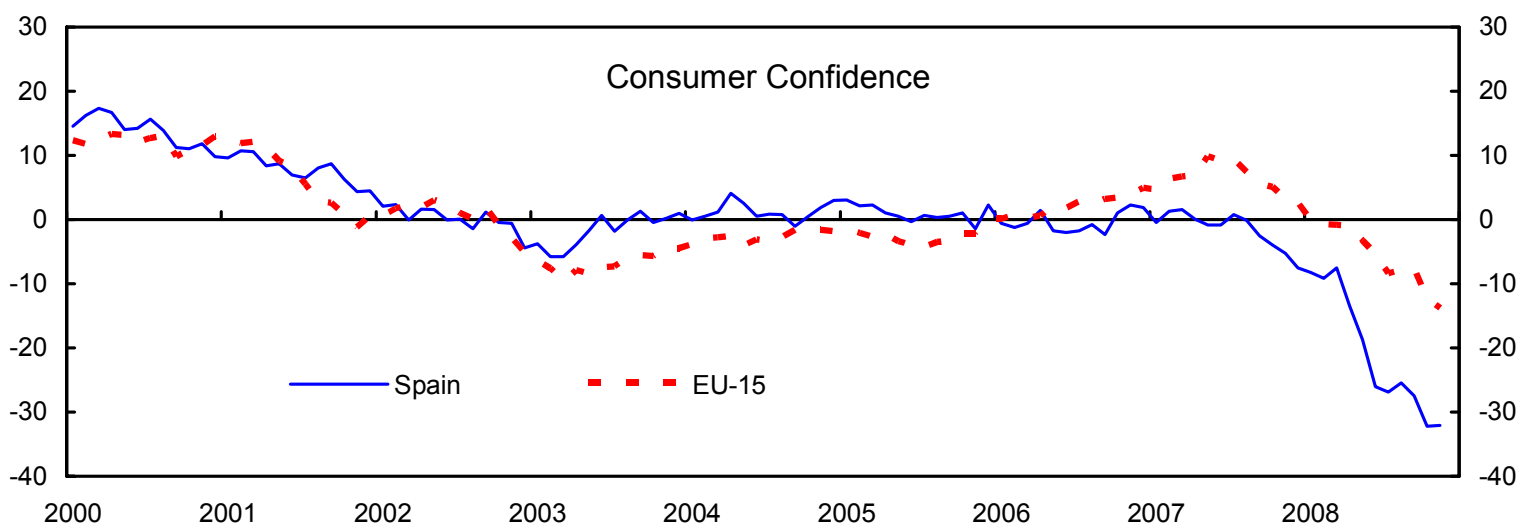

Among sectors, the services providers are most concerned...
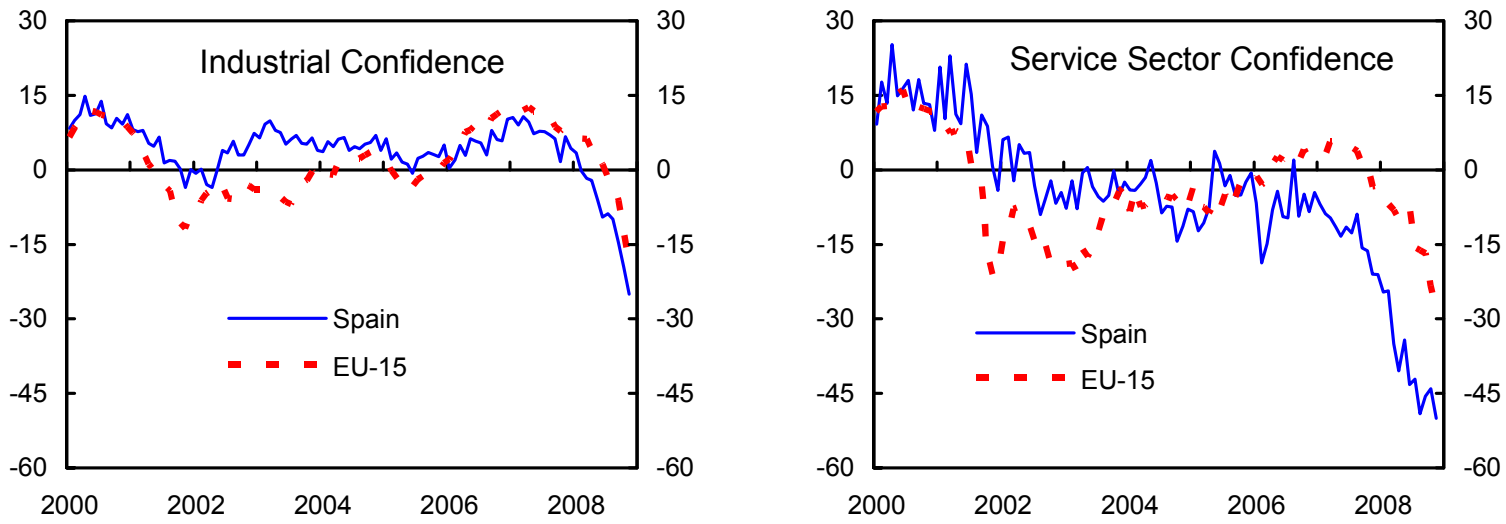

...even more than construction and retailing.
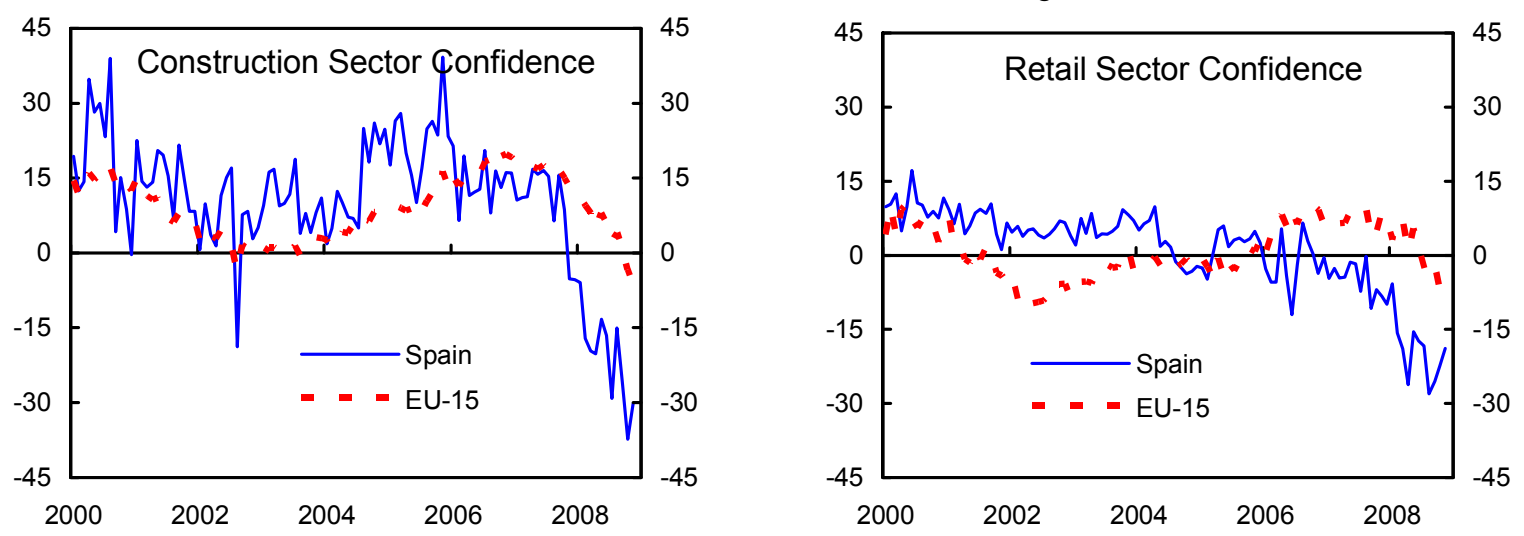

Source: Eurostat; indicators are rebased to average 1985=100. 
Figure 5. Spain--Quarterly National Accounts Reveal the Expenditure Switch from Domestic Demand toward Net Exports

Fixed investment is slumping--led by construction...

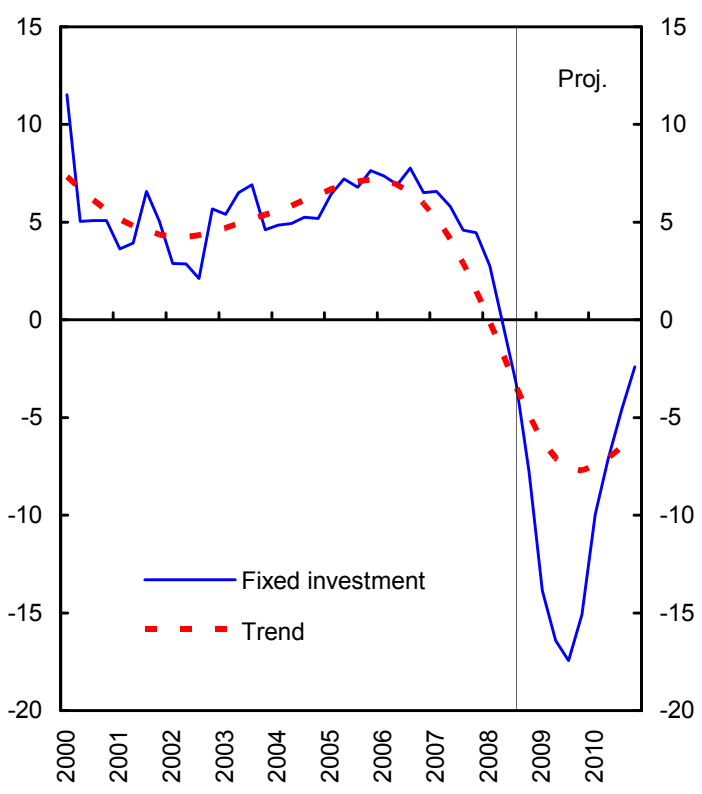

... and private consumption is weakening.

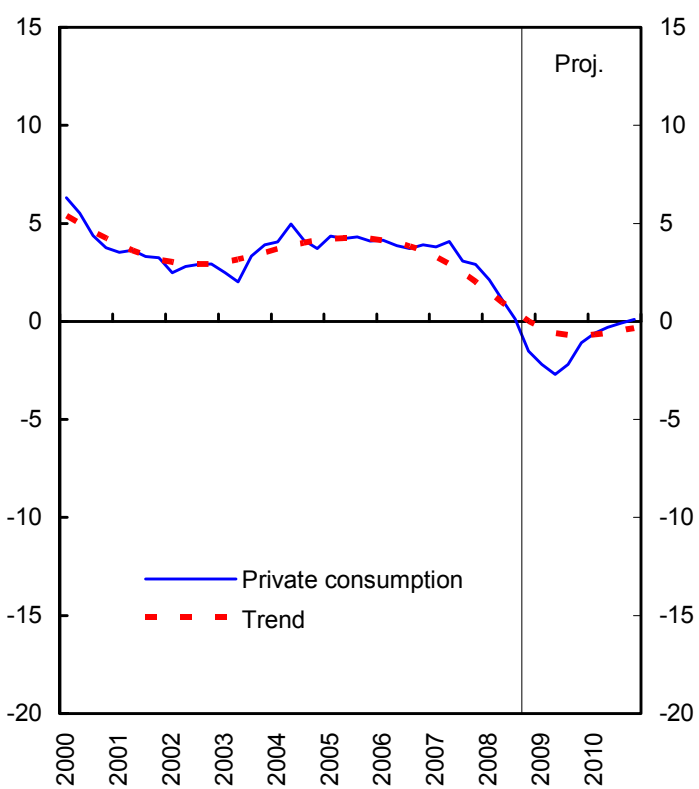

Export growth is holding up despite weak external demand...

...as softer domestic demand depresses imports.
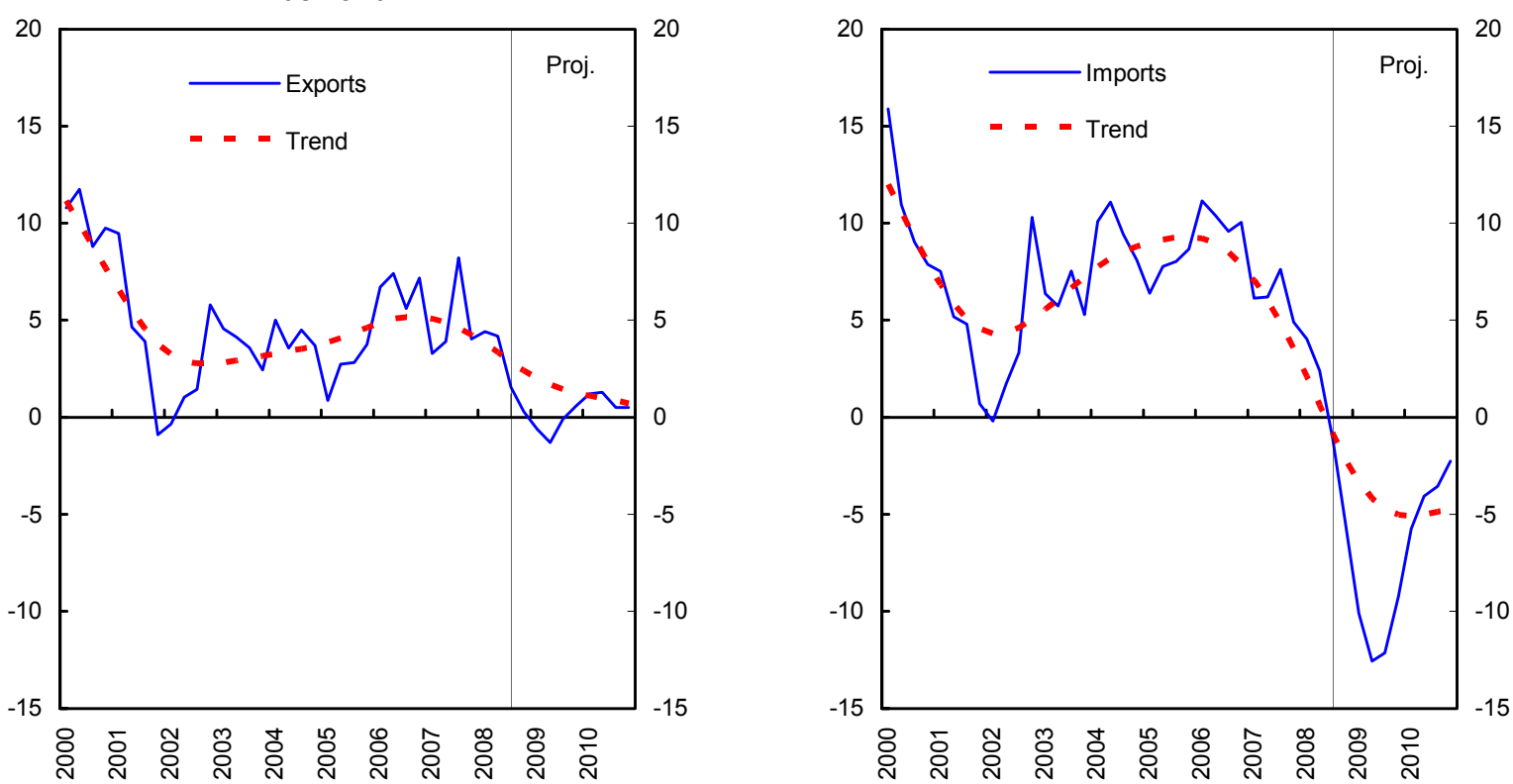

Source: IMF staff calculations based on data provided by the authorities. 
Figure 6. Spain--Balance of Payments and International Investment Position (Percent of GDP)

Merchandise imports have outpaced exports.

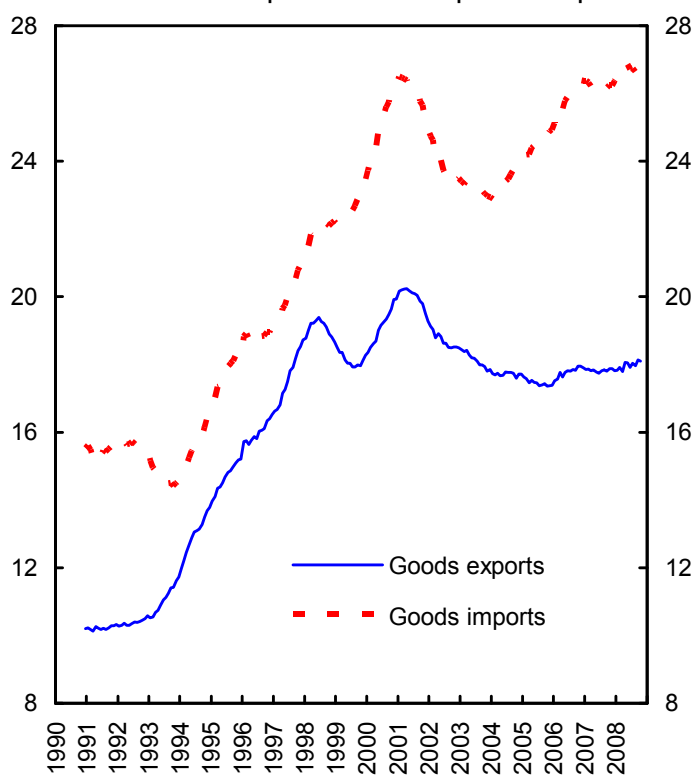

The current account showed growing deficits...

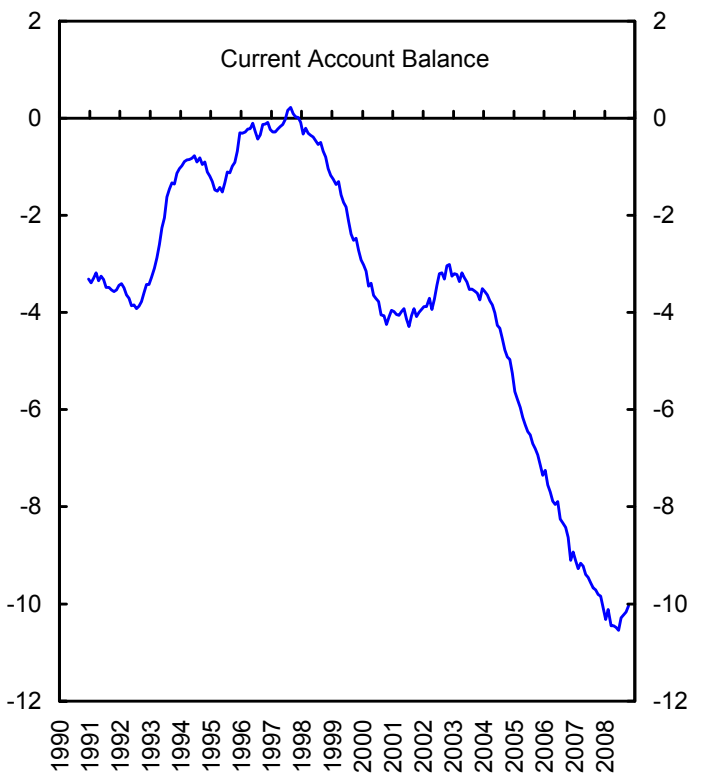

Source: Bank of Spain.
Net factor income has become increasingly negative.

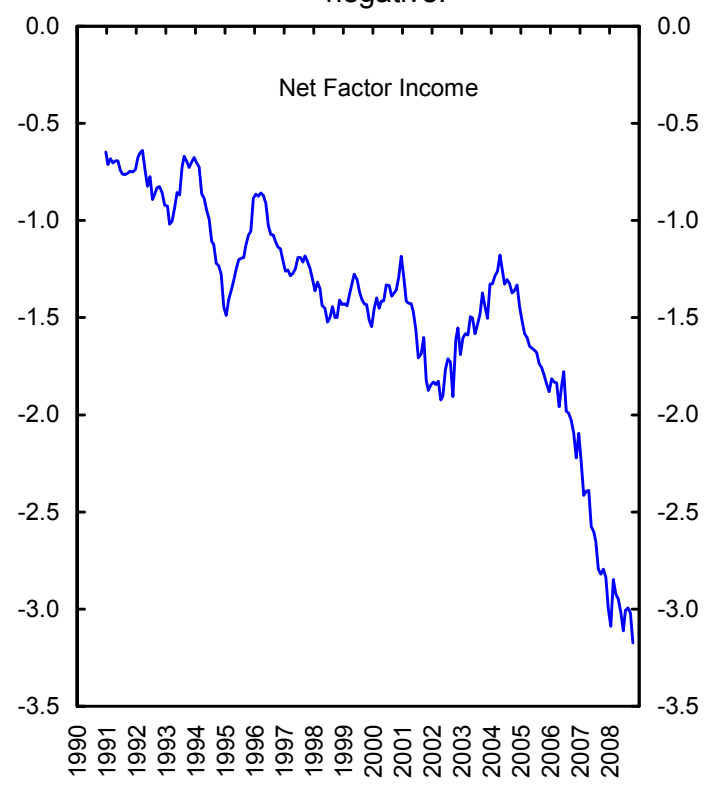

...forcing the IIP into a large shortfall.

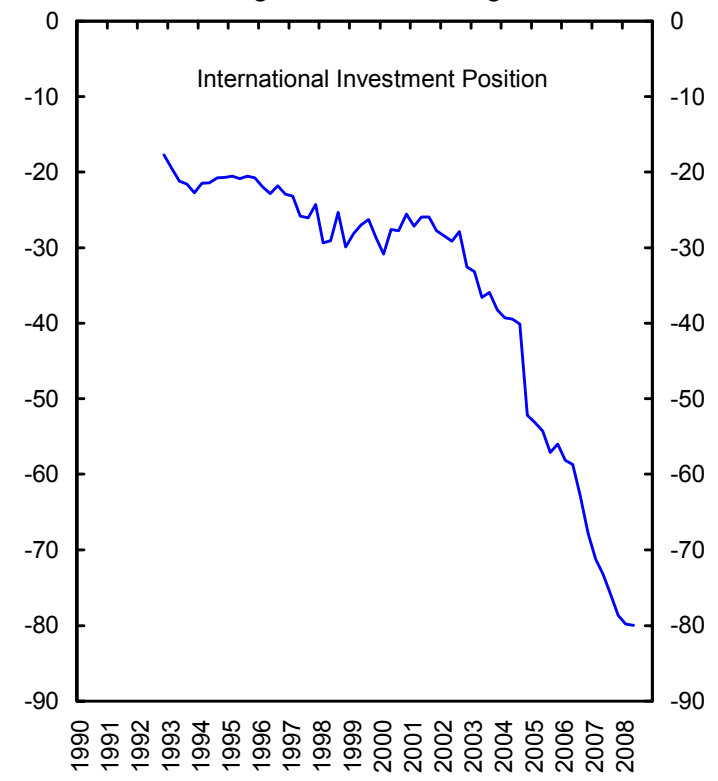


Figure 7. Spain--Inflation and Wages

(Annual percent change)
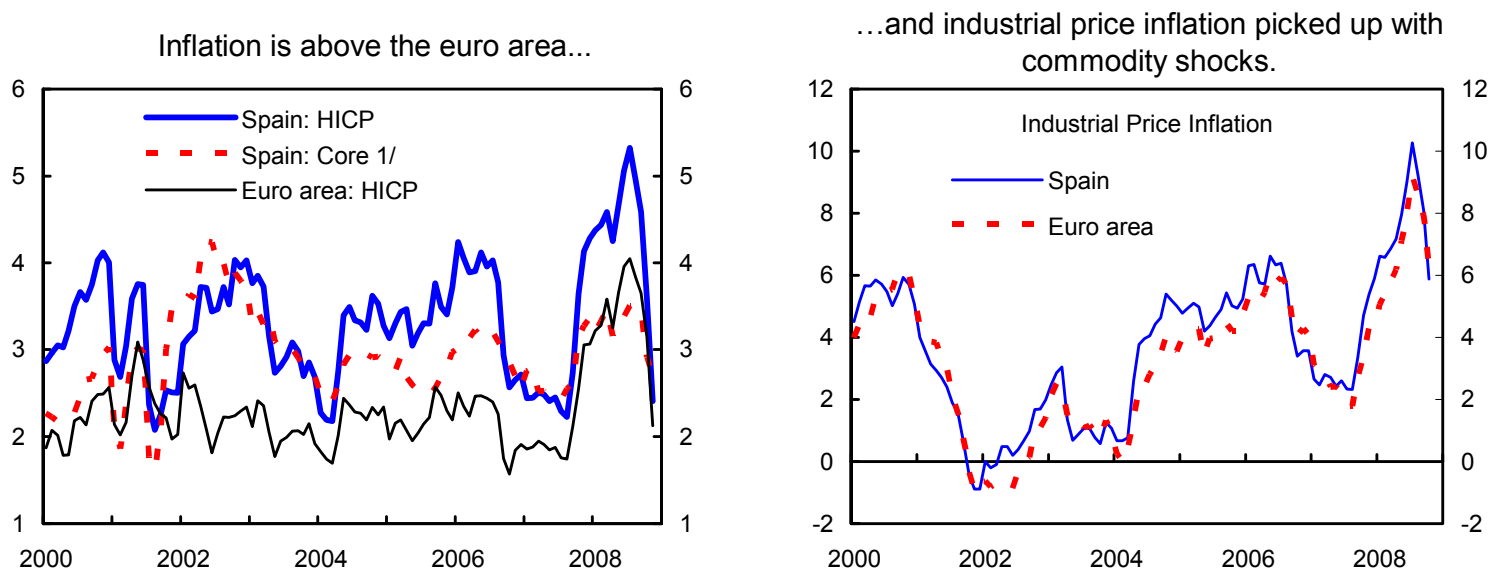

Labor costs per worker are accelerating to 5 percent
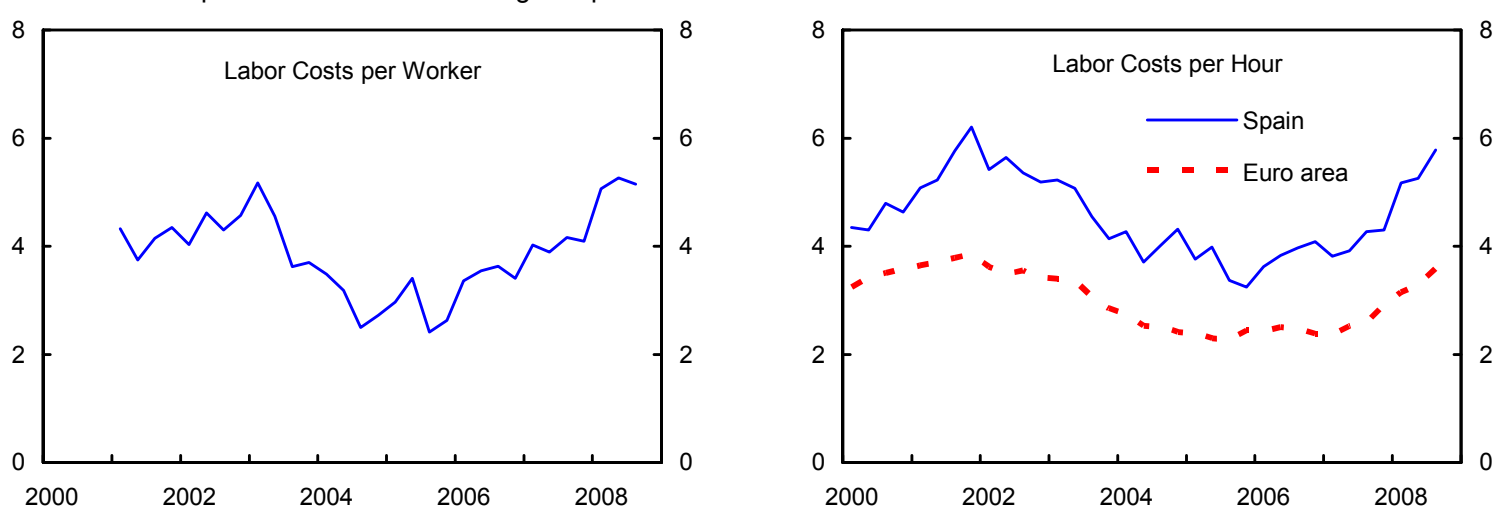

Average labor productivity is ticking up owing to significant labor shedding.

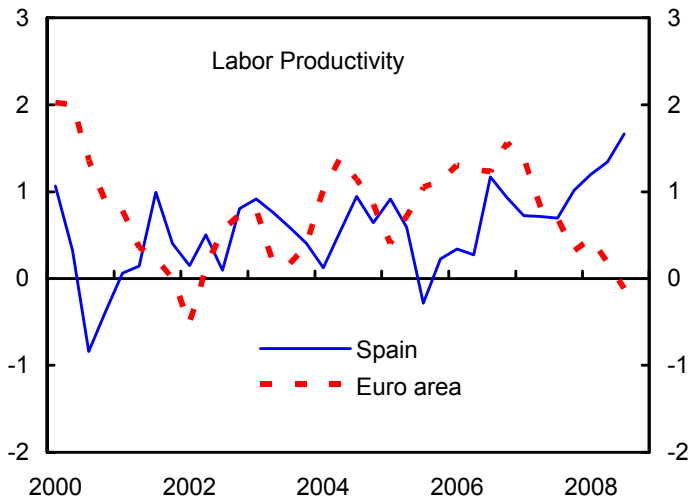

Unit Labor Costs in Manufacturing are far outpacing those of main trading partners.

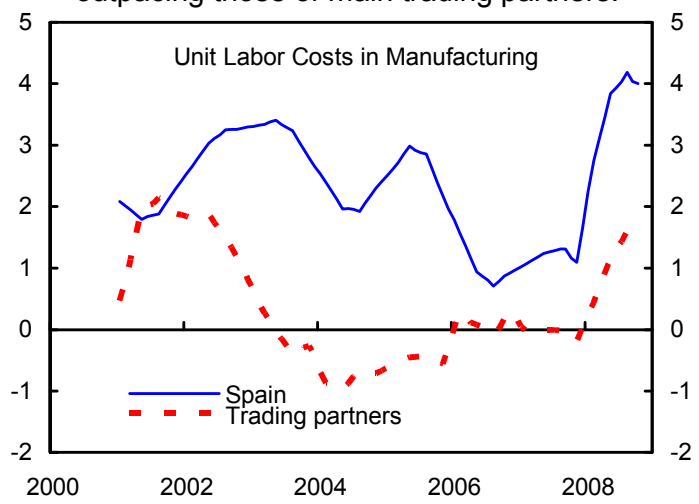

Sources: Eurostat; IMF staff projections based on data provided by the authorities; and WEO.

1/ Excludes nonprocessed foods and energy products. 
Figure 8. Spain--Fiscal Indicators Suggest There Are Risks Ahead (Percent of GDP)

The fiscal balance is turning down very quickly...

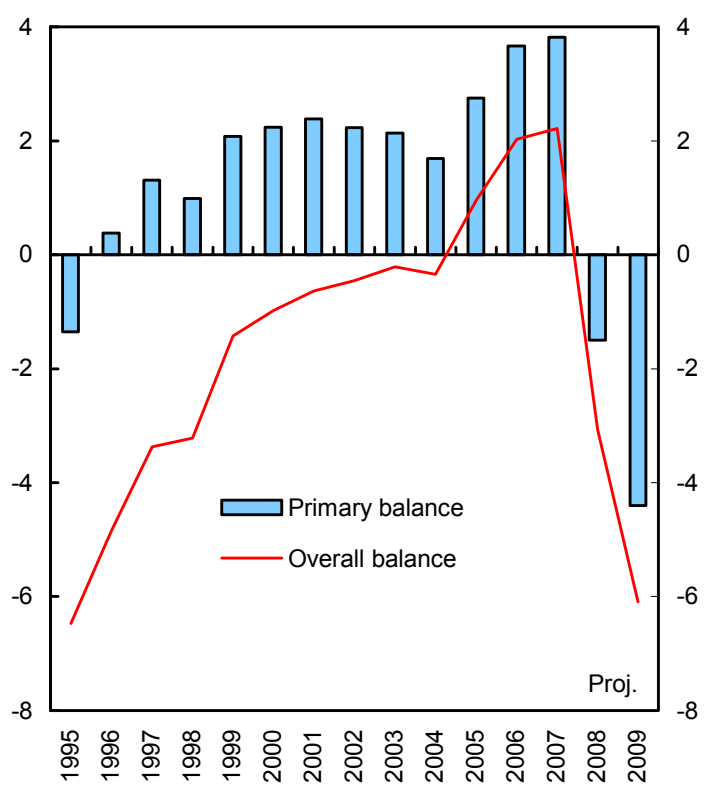

...and primary expenditure has accelerated again...

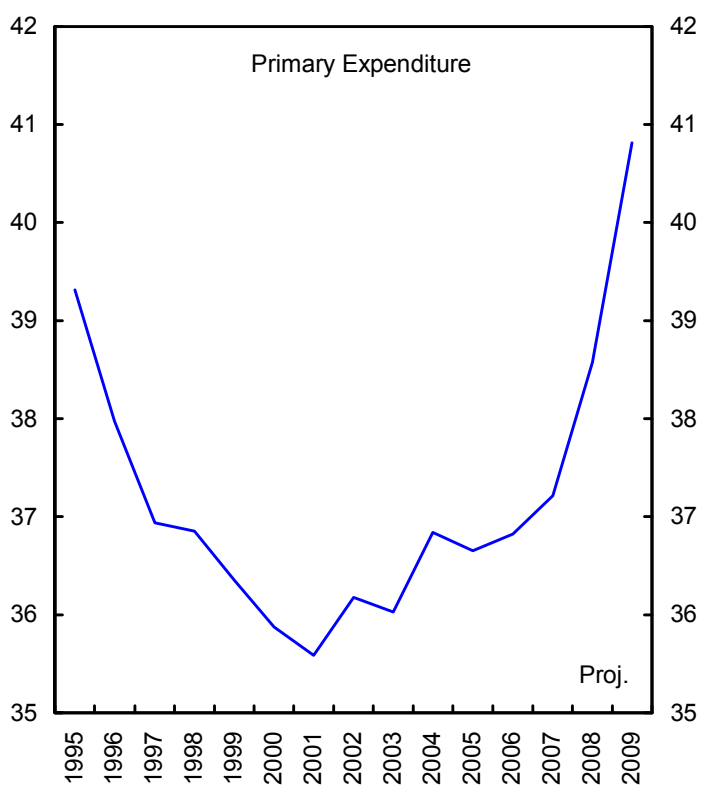

..as revenue slumps together with housing...
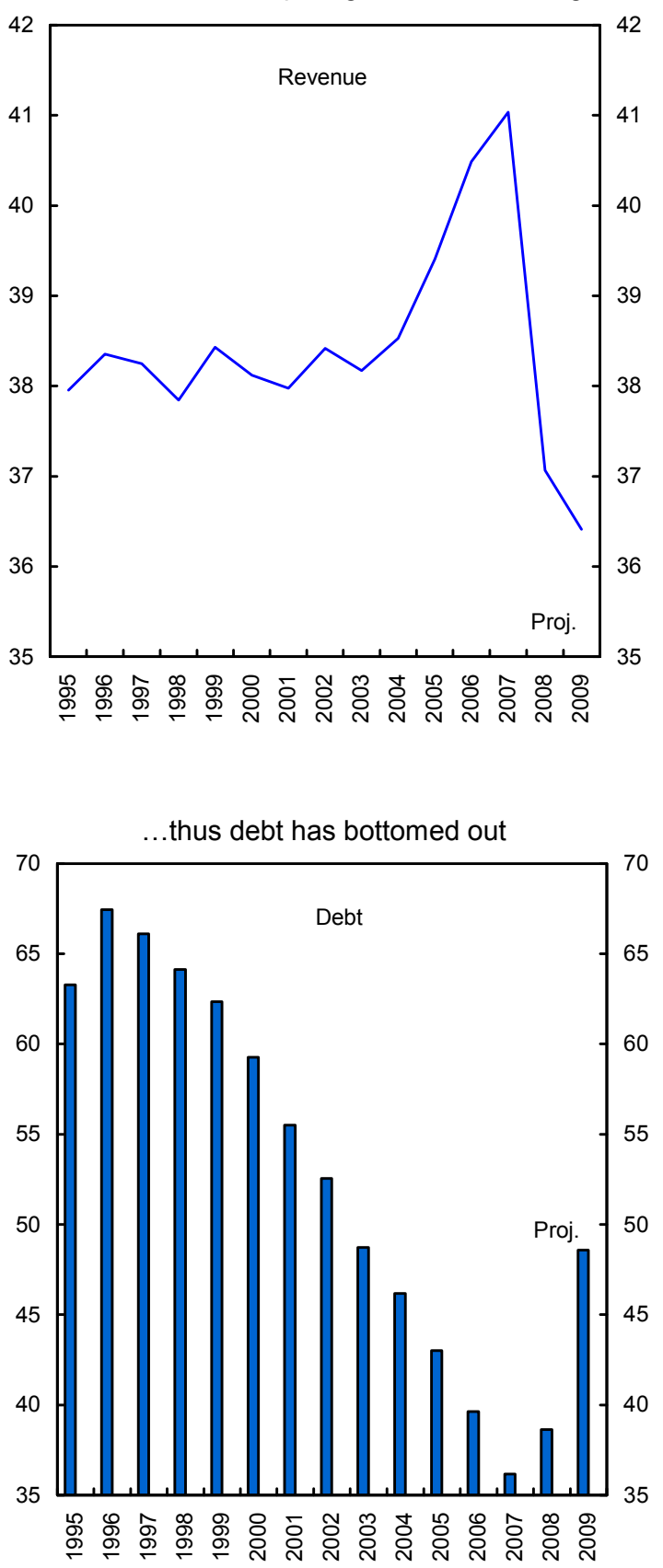

Source: IMF staff projections based on data provided by the authorities. 
authorities' large fiscal efforts. ${ }^{2}$ Consequently, staff and the authorities preferred to analyze the outlook as a range around a baseline scenario.

\section{The staff has lowered its $\mathbf{2 0 0 9}$ growth scenario further to a range between $\mathbf{- 1}$ and} $-2 \frac{1}{2}$ percent with a baseline of -1.7 percent. During the mission, the staff had presented a baseline of (at least) -1 percent, but subsequent data indicate that conditions have worsened with a rebalancing from domestic demand to net exports at a time when foreign demand is also weak. Staff projects inflation to drop to 0.8 percent Spain: Real GDP Growth in 2009, which could be temporarily below EU partners because of Spain's high oil intensity. Unemployment would peak around 17 percent in 2010. Given labor market rigidities, lower demand results in job shedding rather than wage moderation.

Spain: Staff Medium Term Outlook-Baseline Scenario 1/

\begin{tabular}{|c|c|c|c|c|c|c|c|c|}
\hline & 2007 & 2008 & 2009 & 2010 & 2011 & 2012 & 2013 & 2014 \\
\hline Real GDP & 3.7 & 1.2 & -1.7 & -0.1 & 0.9 & 1.4 & 1.6 & 2.0 \\
\hline Total domestic demand & 4.2 & 0.5 & -5.0 & -1.4 & 0.4 & 1.0 & 1.4 & 1.8 \\
\hline Consumption & 3.8 & 1.6 & -0.7 & 0.0 & 0.3 & 0.3 & 0.7 & 1.1 \\
\hline Fixed investment & 5.3 & -2.1 & -15.7 & -6.1 & 0.6 & 3.0 & 3.7 & 4.1 \\
\hline Net exports 2/ & -0.8 & 0.7 & 3.6 & 1.4 & 0.6 & 0.4 & 0.2 & 0.2 \\
\hline Exports & 4.9 & 2.6 & -0.4 & 0.9 & 1.6 & 2.1 & 2.5 & 3.2 \\
\hline Imports & 6.2 & -0.1 & -11.0 & -3.9 & -0.4 & 0.6 & 1.8 & 2.4 \\
\hline $\mathrm{CPI}$ inflation, pa & 2.8 & 4.1 & 0.8 & 1.6 & 1.5 & 1.6 & 2.0 & 2.3 \\
\hline Unemployment rate, pa & 8.3 & 11.0 & 15.6 & 17.0 & 16.9 & 16.3 & 15.5 & 14.4 \\
\hline Potential growth (HP-filter) & 2.1 & 1.8 & 1.6 & 1.5 & 1.5 & 1.6 & 1.7 & 1.8 \\
\hline Output gap & 4.5 & 3.9 & 0.4 & -1.2 & -1.7 & -1.9 & -1.9 & -1.7 \\
\hline Current account balance & -10.1 & -9.7 & -5.5 & -4.2 & -3.8 & -3.5 & -3.3 & -3.0 \\
\hline
\end{tabular}

\footnotetext{
${ }^{2} \mathrm{~A} € 10$ decline in oil prices cuts Spain's import bill by 0.8 percent of GDP annually. A 100 basis point decline in the 12-month euribor saves homeowners 0.6 percent of GDP in mortgage interest payments annually.
} 
Spain: Staff Quarterly Base line Scenario 1/

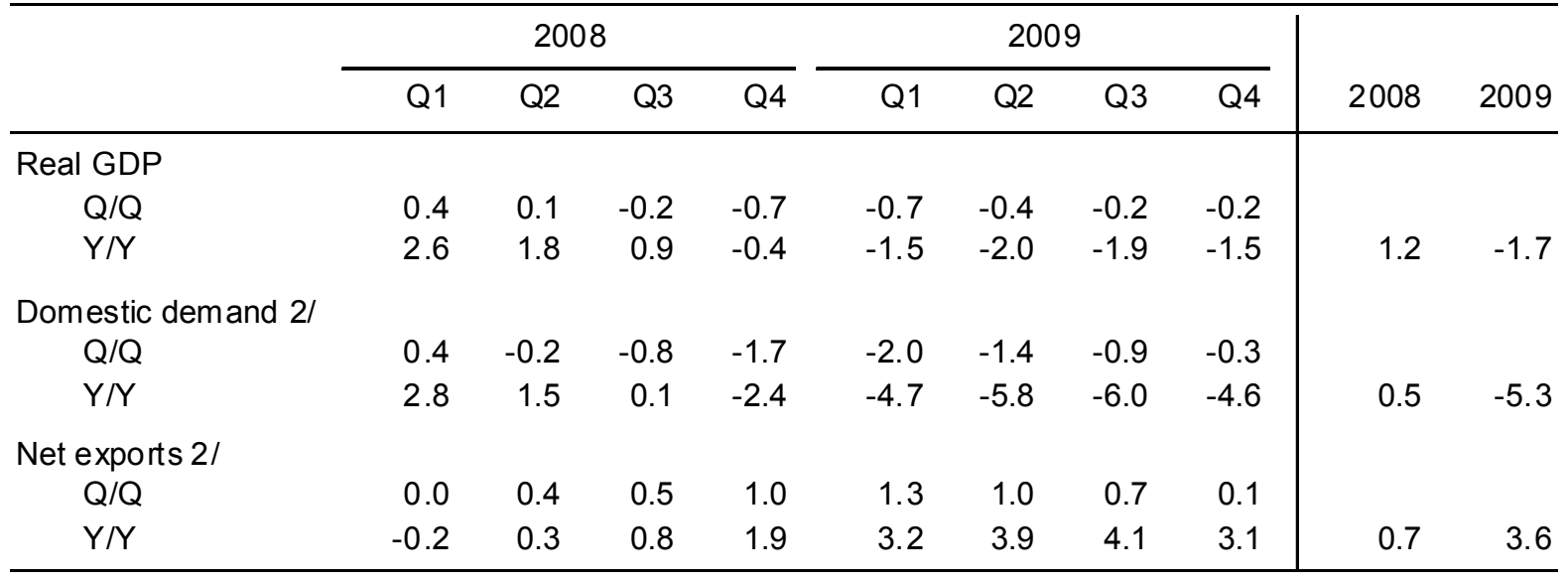

$1 /$ In percent.

2/ Contribution to growth.

\section{The balance of risks around the staff baseline is on the downside, and the}

forecast range is wide. The drop in oil prices and euribor are supporting disposable income, but it is unclear how much finds its way into spending versus saving to restructure private balance sheets - i.e. how long and deep deleveraging will be. The upside range assumes a smaller increase in household saving than $2 \frac{1}{4}$ percentage points assumed in the baseline; the downside range assumes saving rates jumping by $3 \frac{3}{4}$ percentage points. Further, downward risks could materialize as external demand from the EU continues to weaken (2009 import volumes from euro-area partners are currently projected to drop between 1.5-2 percent). Furthermore, the slowdown in Latin America and other markets may feed back through the significant interlinkages of Spain's large banks ( $\mid 30)$, thus worsening domestic credit conditions. Finally, high unemployment and extended slow growth would continue to put pressure on Spain's domestic banks as well, which could slow credit growth yet further.

\section{Without more reforms to increase flexibility, staff is concerned that Spain could} get stuck in a low-growth extended-adjustment (L-shaped) equilibrium. Such a scenario has been experienced by Portugal, Germany, and Japan. If the structural inflation premium over euro partners persists and deleveraging requires time, immigration could subside and actual and potential growth remains weak. The cumulative loss of competitiveness and high private sector indebtedness thus restrain growth. Construction, which has been the engine of growth, is unlikely to rebound soon. The switch to higher productivity will likely be slow with timid product and labor market reforms, as assumed in the staff's medium-term outlook.

15. The authorities expect a more $\mathbf{V}$-shaped recovery. They note the higher population dynamics in Spain relative to trading partners (immigration would still contribute to growth). Spain's attractiveness as a residential destination for many Europeans would support the housing market to some extent, which could lead to a gradual recovery from 2010. So far, Spanish export market share has held up relatively well — seen to reflect better competitiveness than relative prices may indicate. The authorities view some of the inflation 
differentials as catching up with trading partners (Balassa-Samuelson effects), but agree that competitiveness should be improved. They prefer to focus on output market reforms to assist productivity, with less emphasis on labor market reform.

\section{Policy Discussions}

16. The discussions centered on the deteriorating outlook on the back of the housing correction and its implications for banking, fiscal policy, and structural reforms. Interlocutors agreed that the housing market needs to stabilize to bolster the quality of bank assets. Banks need funding access and sufficient capital to manage the effects of the crisis. Fiscal policy is providing liquidity to the economy and propping up activity and employment to the extent possible. Staff stressed the need to calibrate these measures in a long run sustainability framework to assure a return to lower debt and boost confidence. In this vein, structural reforms need to complement cyclical-support policies by lowering costs and increasing productivity to raise growth potential. Several interlocutors remarked that the political system was not interested in the long-run at this moment. Support for reforms was said to be uneven, especially for labor reforms.

\section{A. Housing}

17. Spain has achieved a major upgrade of its housing stock. The renewal in the Spanish housing market reached a crescendo in 2006 when Spain started nearly 800,000 homes - more than Germany, France, Italy, and the UK combined. Construction value-added reached 17 percent of GDP, more than double in other countries. Construction employment was also very high, including using immigrant labor.

\section{However, the $\mathbf{2 0 0 7}$ funding crunch brought the boom to a halt, and adjustment} will take time given a large inventory (Figure 9). Estimates differ. The authorities estimate a stock of at least 600,000 unsold homes, to increase somewhat as new units are being finished. The private sector estimates a stock of 1 million, compared with demographically sustainable sales of some 400,000 homes a year. With peak housing starts nearing completion, inventories will likely expand throughout 2009.

19. House price data diverge - predictions of future house prices more so. Official statistics on assessed value per square meter suggest that prices are now slightly down $\mathrm{y} / \mathrm{y}$. A new official series on home prices per dwelling has started to show more substantial nominal declines. Home prices by private assessors or average market asking prices suggest that nominal home prices are already falling over 10 percent $y / y$. The staff is positing a scenario of house prices falling by 30 percent in real terms over four years (peak/trough), and construction activity to bottom out at the earliest in 2010. The authorities feel that this price

\footnotetext{
${ }^{3}$ The background paper on housing provides a detailed analysis.
} 
Figure 9. Spain: Housing Market Indicators

From permits to starts to finishes takes 2 years, implying house supply could exceed long-run sustainable demand into $2010.1 /$

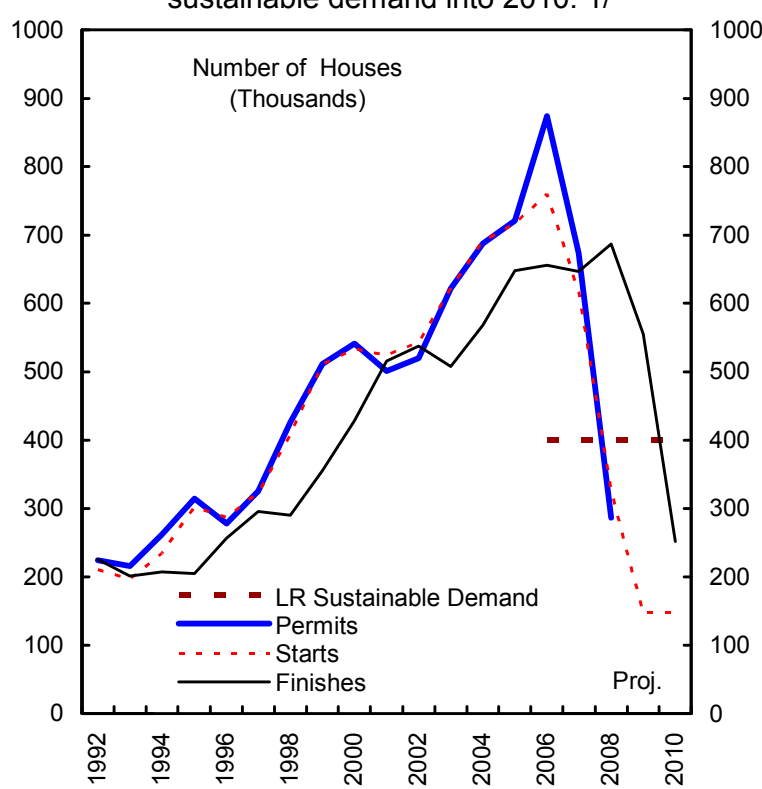

House prices may decline significantly to work off the large excess supply suggested above. 2/

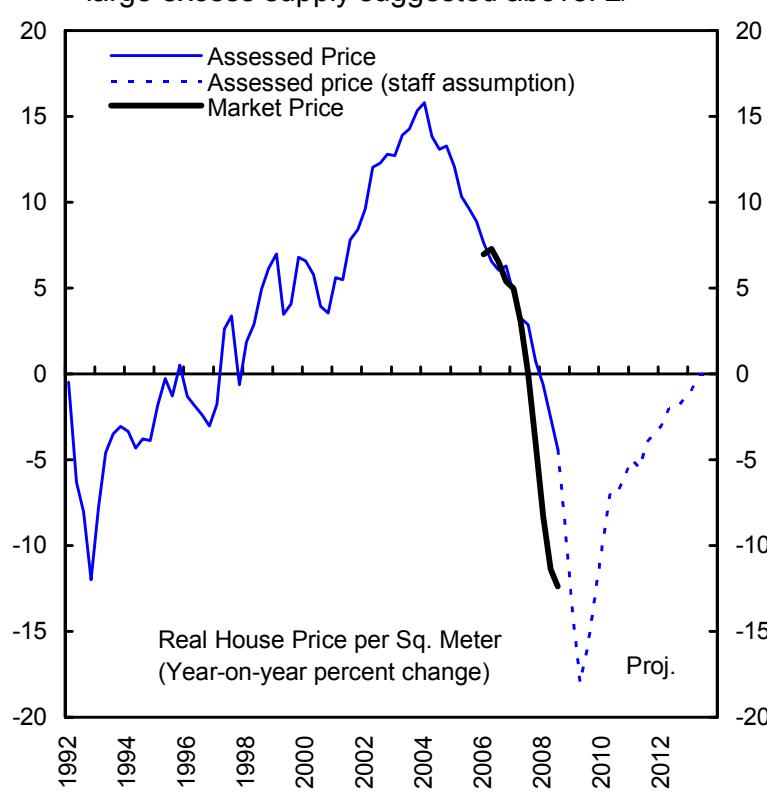

The value of new monthly mortgage lending is plummeting, consistent with a sharp drop in demand.

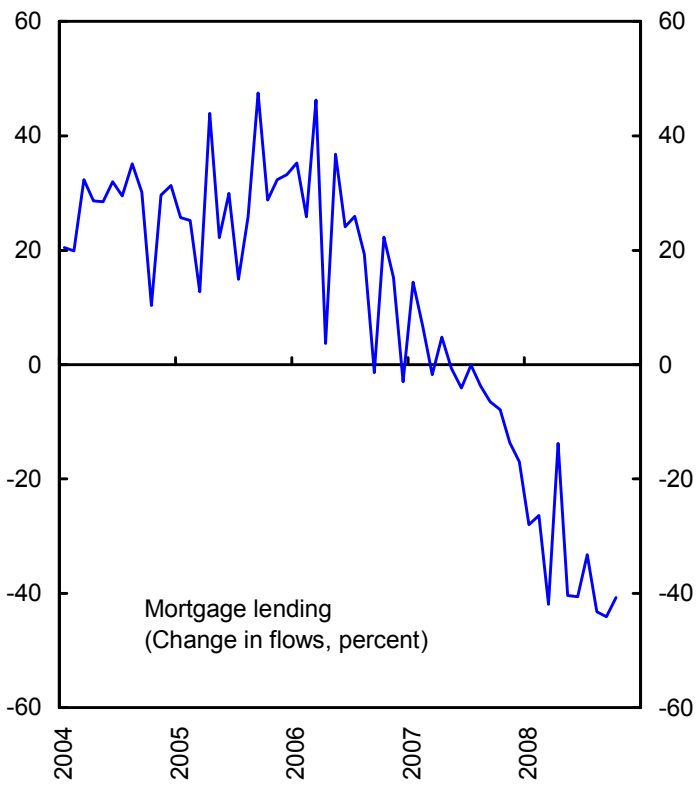

Monthly principal \& interest costs of adjustable mortgages have risen quickly with the 12-M

\section{Euribor.}

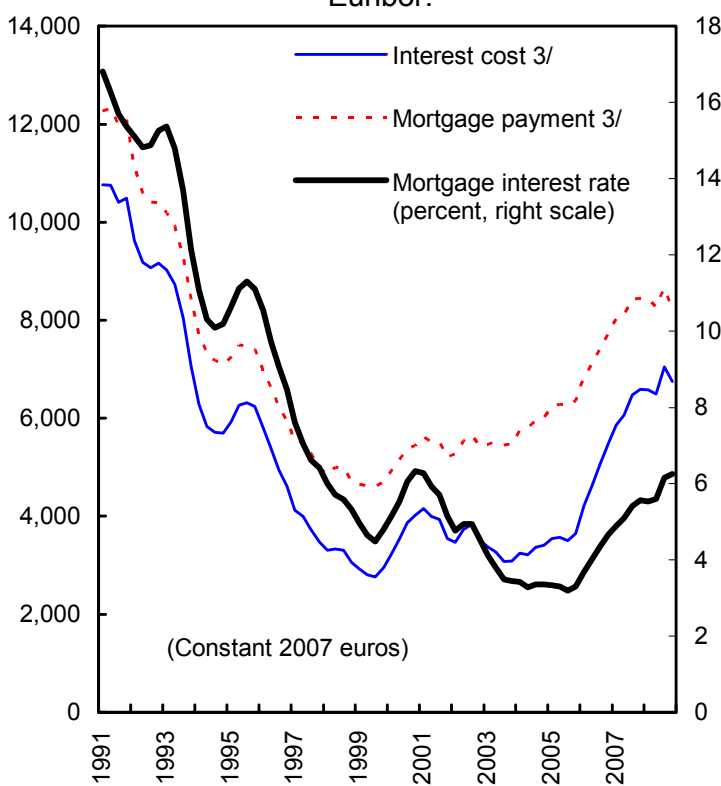

Source: Staff calculations and projections based on data provided by the authorities, and Fotocasa.

$1 /$ These are flows of newly built houses; does not take into account existing excess inventory.

2/ Assessed house prices represent the official house price series deflated by the CPI. This indicator has been lagging market house prices recently. Market house prices are from Fotocasa, a private firm.

3 / Initial annual payments on a typical new mortgage, defined as an 80 percent loan-to-value mortgage on a home priced at 149,000 euros in 2007. 
drop is too high due to housing market segmentation and downward price stickiness. However, banks' contingency plans closely match staff assumptions - an extended correction with significant price declines.

\section{The implications are important:}

- Higher unemployment. Slowing construction may release 1 million workers (5 percent of total employment in the economy).

- Pressure on banks. Mortgage credit is 35 percent of loans; construction and real estate company credit another 25 percent. Deteriorating asset quality is affecting the banks' profitability, and funding, which depends heavily on mortgage-backed securities.

- Weaker public finances. Escalating asset prices and transactions lifted revenue. Estimates of sustainable revenues and the structural fiscal position have been too optimistic, in staff's view.

\section{The authorities have taken several measures to assist the construction sector.}

They aim at creating jobs (including through public infrastructure), facilitating mortgage refinancing, limiting foreclosures, ${ }^{4}$ promoting the rental market, and expanding subsidized housing. Many interlocutors among banks and analysts felt that these measures were useful and timely.

\section{Staff agrees that the housing measures have been valuable, and sees some}

further room for improvement. While home-ownership is (overly) subsidized through tax deductions, the market for rentals is underdeveloped, hindering labor mobility, and there is potential to absorb vacant housing stock. In this context, restrictions need to be relaxed, such as the landlord's obligation to automatically renew the lease during the initial five years (the tenant can quit, but not the landlord), and capping of rent increases at CPI indexation. Eviction rules are being clarified to protect homeowners while mediation is being revamped to safeguard consumer rights. Staff cautioned against constructing more subsidized housing at this time, which adds to supply, and does not always reach the vulnerable groups intended. The authorities said that this keeps employment up and were in a market segment that did not interfere with the free housing sector.

\footnotetext{
${ }^{4}$ The authorities are working with attorneys and banks to lower refinancing fees; and are implementing a program in which newly unemployed workers with dependents could defer half of their monthly payment for a period of two years (to be amortized subsequently over 10 years). The deferred amounts would have government guarantee.
} 


\section{B. The Banking Sector}

\section{The banking sector has weathered well the initial impact of the global crisis} thanks to prudent regulation, sound supervision, and cautious retail-oriented business models. On the asset side, Spain's dynamic loan-loss provisioning helped build cushions during good times (Box 1). Also, rigorous consolidation rules reduced incentives for off-balance-sheet vehicles and banks avoided investing in opaque structured products. On the funding side, banks used their extensive branch networks to gather deposits, but also issued large amounts of asset-backed securities, mainly covered bonds. ${ }^{5}$ It is estimated that the dynamic provisions have "bought" banks about two years worth of cushion ( $€ 24$ billion), which are now starting to run low. Banks continued to record healthy profits in 2008, maintained moderate leverage and sound capital adequacy, and no bank was closed or intervened (Tables 2 and Spain: Banking Indicators (percent)

\begin{tabular}{lrrrr}
\hline & 2005 & 2006 & 2007 & $20081 /$ \\
\hline Return on equity & 16.8 & 19.6 & 19.7 & 16.8 \\
Return on assets & 0.9 & 1.0 & 1.1 & 1.0 \\
Operating expense/gross income & 49.1 & 41.9 & 43.4 & 47.1 \\
CAR & 12.0 & 11.9 & 11.4 & 11.3 \\
Tier 1 & 8.2 & 7.6 & 7.9 & 8.2 \\
Leverage 2/ & 6.0 & 6.0 & 6.3 & 5.9 \\
Deposits/loan ratio & 80.4 & 79.7 & 78.8 & 78.1 \\
Liquid/total asset ratio & 34.1 & 29.7 & 29.2 & 28.6 \\
NPL ratio & 0.8 & 0.7 & 0.9 & 3.2 \\
Impaired loan coverage ratio & 255.5 & 272.2 & 214.6 & 71.9 \\
\hline
\end{tabular}

Source: Bank of Spain.

1/ Latest data available, mostly June-November.

2/ Unweighted bookvalue capital/asset ratio.

3, and Figures 10, 11).

\section{Nevertheless, financial market disruption has severely affected banks' operating} models. The banks are restructuring their balance sheets. On the liability side, they have intensified competition for deposits, stepped up recourse to the ECB (with another run-up at end-2008), and availed of government funding assistance (below). On the asset side, they slowed lending to the euro-area average growth rate, sold industrial participations, and tightened credit standards while seeking workouts with distressed property developers.

\section{The authorities have taken measures to assist bank funding, rather than} purchasing bank assets or injecting capital (Box 2). Bank assets are mainly loans, which are granular and less volatile than exotic products held in other banking systems. This provides Spanish banks some time to adjust. At this stage, the authorities prefer not to intervene directly by purchasing assets, because banks are best placed to manage these. For contingency purposes, the authorities have adopted legal provisions for potential capital support. They have refrained from capital injections so far and will continue to do so to the extent possible to promote private sector market-based solutions first, and to avoid distorting competition. Staff agrees. Indeed, the authorities expressed concern that government-led

\footnotetext{
${ }^{5}$ These provide double collateral - the securitized assets and the bank's own separate pledge.
} 
Figure 10. Spain--Financial Sector Indicators (I) (Year-on-year percent change, unless otherwise indicated)

Household debt is over 130 percent of disposable income.

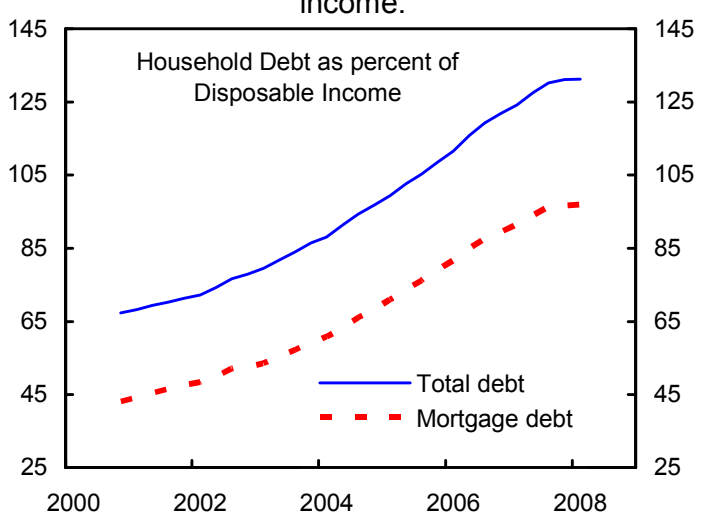

Asset quality is slipping, NPLs have increased

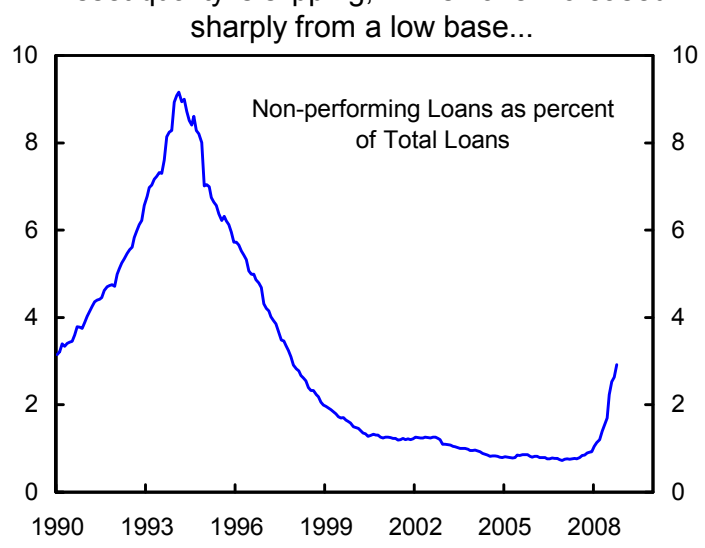

Spanish banks went from being below-average to average users of ECB liquidity facilities...

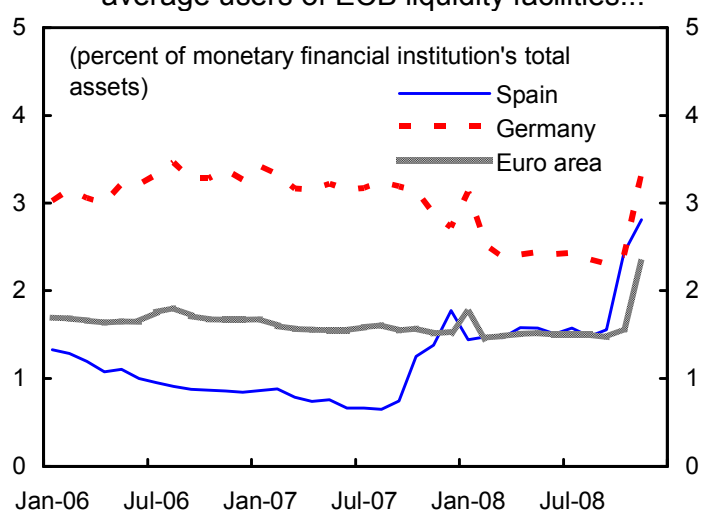

Corporate debt is over 110 percent of GDP.

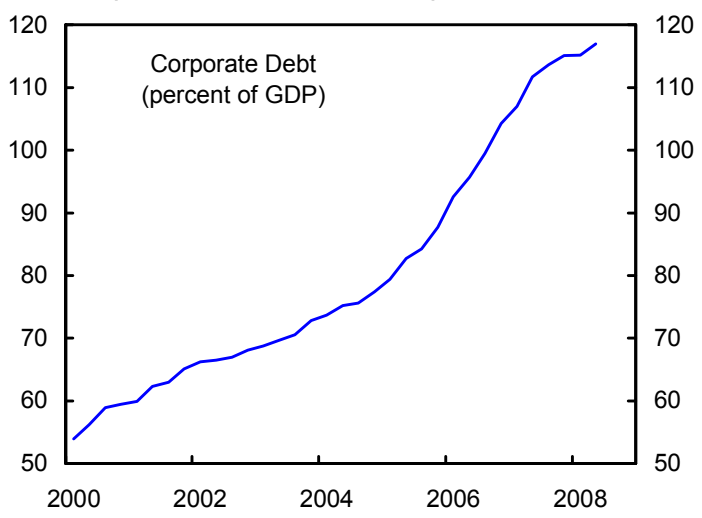

...while funding costs are rising.

Spreads on covered bonds are increasing.

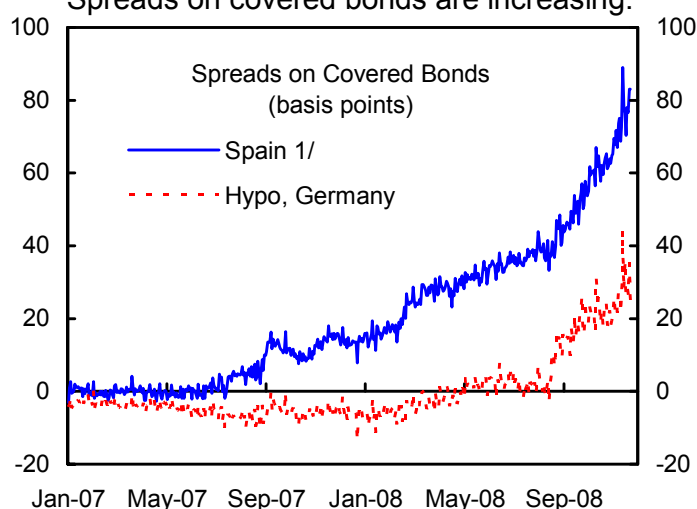

...but loan to deposit ratios are higher than average, implying high dependency on wholesale markets.

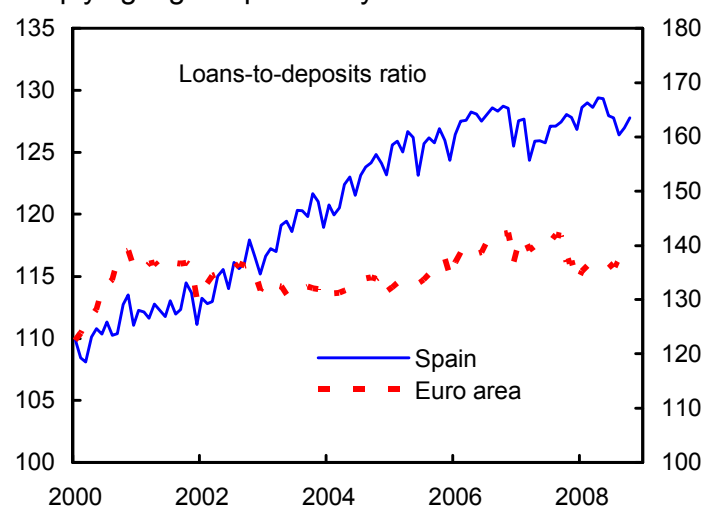

Sources: Bank of Spain; ECB; and data provided by the authorities.

1/ Simple average of asset swap spreads on covered bonds by Santander, BBVA, Caja Madrid, and Caixa Barcelona. 
Figure 11. Spain: Financial Sector Indicators (II)

Credit growth is slowing, but banks have picked up deposit competition.

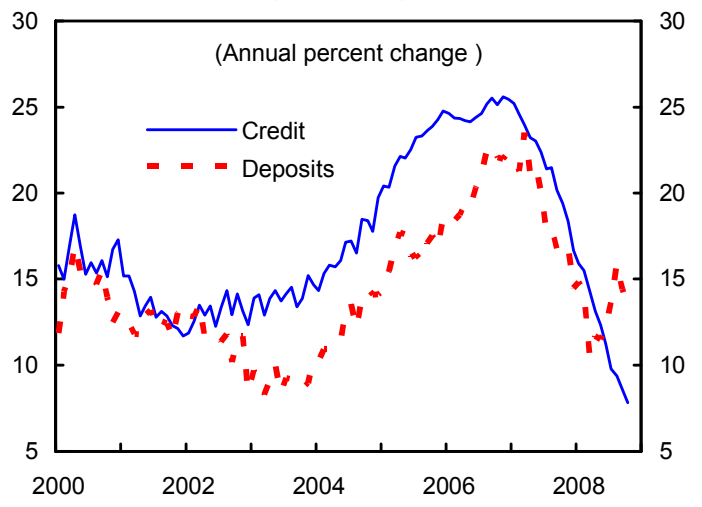

The banks have large amortizations falling due.

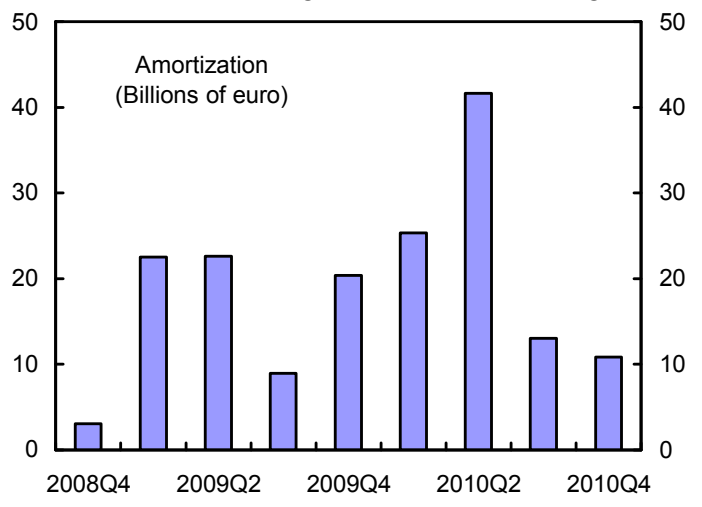

...as do some private banks...

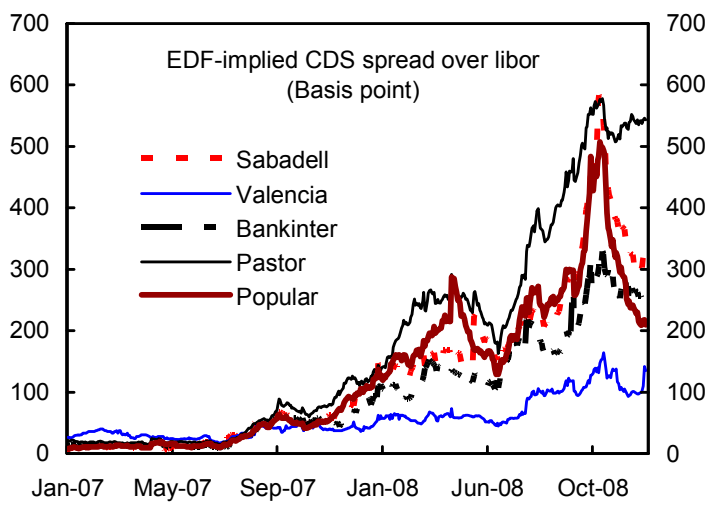

The Bank of Spain's countercyclical provisioning is proving its worth.

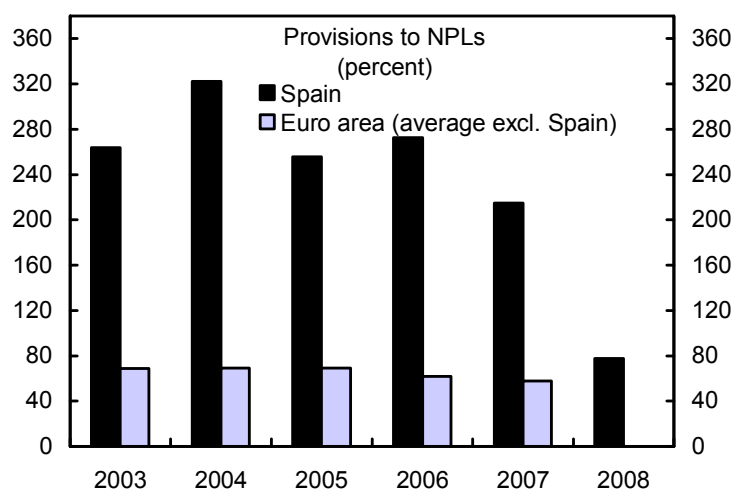

Some cajas show troubling CDS spreads...

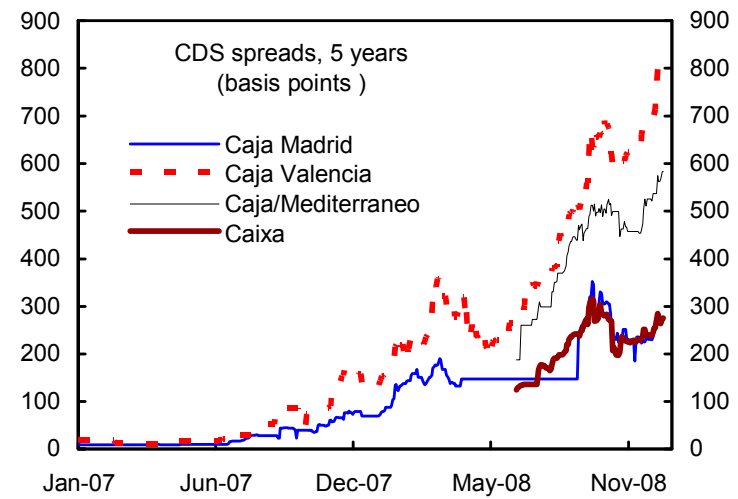

....and their probabilities of default have increased.

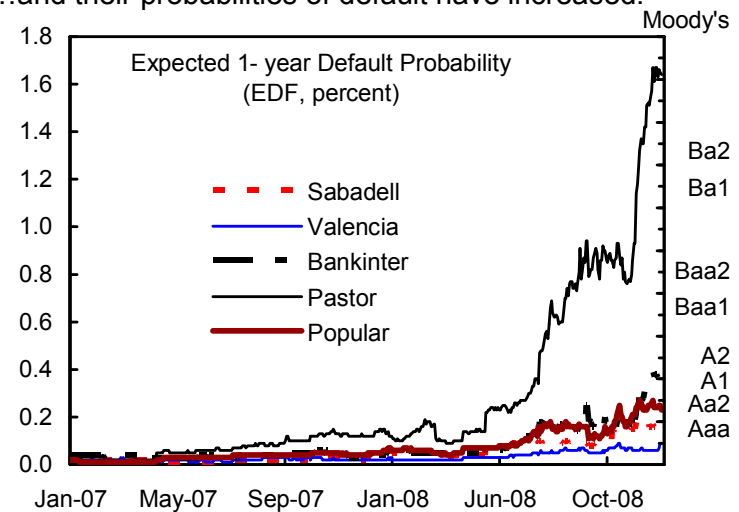

Sources: Data provided by the authorities; Bank of Spain; ECB; and Bloomberg. 


\section{Box 1. The Spanish Prudential Framework}

Dynamic loan-loss provisioning has built buffers before the current stress materialized; and rigorous consolidation rules have reduced incentives for off-balance-sheet vehicles. Both features are attracting international attention.

Dynamic loan loss provisions-The Bank of Spain (BdE) has pioneered the use of dynamic provisions since 2000 to mitigate credit procyclicality. ${ }^{1 /}$ The principle recognizes that potential loan losses may exist from the moment a loan is granted - and this requires a provision. Hence, Spanish banks are required to create two provisions: specific, against identified losses or doubtful assets, and general, against potential losses. For the latter, banks' standard loans are subdivided into six risk categories with corresponding provisioning coefficients, determined by historical experience of impairment and loss given default. In each quarter, banks are required to set aside general provisions equal to the difference between a notional amount of provisions and the amount of specific provisions accumulated during the period (notional provisions being a function of the flow and stock of banks' exposure in each risk category multiplied by the respective provisioning coefficient). The total stock of general provisions is required to remain within predetermined limits. ${ }^{2 /}$ Dynamic provisioning helps build cushions during expansions, which partially smooth bank profits and solvency over the business cycle. The estimated $€ 24$ billion in provisioning cushions in banks resulted in nonperforming loan (NPL)-coverage ratios of over 200 percent at the peak, compared with the EU average equivalent of just over 60 percent.
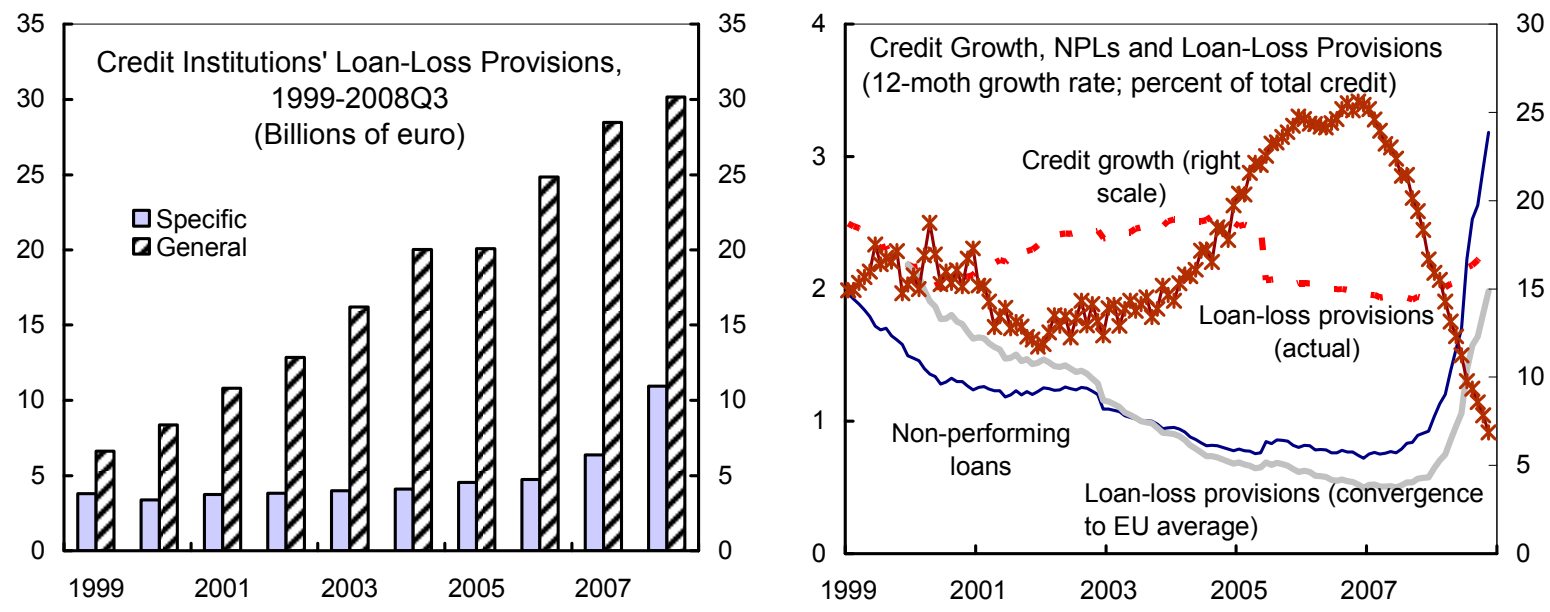

Source: Banco de España, Statistical Bulletin .

Securitization and consolidation practices-Securitization began in 1982 with initiatives to develop the mortgage markets and has grown strongly since 1992. Before adopting IFRS in 2005, it was normal for banks to effectively remove securitized loans from their books. In adopting IFRS, the BdE extended to individual institutions the application of accounting criteria for the consolidated level. In addition, risk transfer and control of special purpose entities were defined in strict terms. Both steps reduced incentives for off-balance sheet securitization and capital relief.

1/ The framework was reformed in 2005 to comply with IFRS (Circular 4/2004).

2/ Currently the limits are 0 and 125 percent of bank exposures multiplied by their respective provisioning coefficients (Circular 6/2008). The BdE maintains an indicative minimum level of 10 percent (Actualizado Circular 6/2008). 
recapitalization of weak institutions elsewhere had already created significant distortions in the EU. In their view, Spanish vulnerability is on the funding side - especially wholesale funding with forthcoming debt amortizations of about $€ 170$ billion in the next two years. Thus, the authorities have put in place facilities to help banks cope with funding tightness and increased deposit insurance together with EU partners to assist confidence.

\section{Box 2. Bank Support Measures}

Spain is assisting the banking system in line with the common framework agreed by euro-area countries:

- The limit on deposit insurance was raised from $€ 20,000$ to $€ 100,000$. Moreover, the deposit information system was strengthened to allow a timely response in emergencies.

- A $€ 30-50$ billion fund was established to purchase high-quality securities issued by credit institutions (FAAF). The auctions are modeled after, and complement, the ECB liquidity facilities, but with longer maturities up to 3 years. Up to 25 percent of a tender may be allocated through noncompetitive bids to credit institutions in proportion to their contribution to credit growth. Limits have been envisaged to safeguard sufficient diversification in allocation among institutions. Four auctions have been carried out with positive results in allocated amounts and spreads.

- Government guarantees are provided for credit institutions' new debt issues. The amount approved is $€ 100$ billion to be used by mid-December 2009. A possible additional $€ 100$ billion might be allotted in 2009 if market conditions do not improve. Pricing is agreed with EU partners as a minimum of 50 basis points plus a factor that depends on the CDS spreads and/or the rating of the originator. Many banks will participate in this program.

- If necessary, credit institutions' recapitalization may be carried out through the government's acquisition of nondiluting instruments such as preferred shares.

\section{Turning to 2009, it was agreed that Spanish banks face a very difficult year,} likely leading to bank consolidation. Balance sheet restructuring is contributing to the slowdown. Several large real-estate developers have filed for bankruptcy. Impaired loans have jumped, although from a very low base, eroding prudential cushions. CDS spreads have widened (sometimes a thinly traded indicator) and bank share prices have dropped, reflecting prospects of continued economic weakness and in property markets.

\section{Staff stress tests based on published data suggest that banks may face capital} needs - Bank of Spain's results, using detailed internal data, are more benign, but the authorities are not complacent. ${ }^{6}$ The staff assumes that significant pressures will still build on profits and asset quality in 2009 as the housing and growth downturn unfold. Staff noted that there is a need for (fiscal) contingency plans to assist banks with capital. The authorities viewed the severe scenario by staff as too pessimistic, especially regarding the assumption of loan impairments rising rapidly to double digit NPL-ratios. This was in part because the

\footnotetext{
${ }^{6}$ The background paper on the financial system describes the staff stress tests on credit risk.
} 
authorities envisage a somewhat smaller downturn and housing price decline than staff, and because regulations for loan impairment have been tightened relative to the early 1990s, which results in higher NPL statistics for any given economic scenario today relative to the early 1990s. Also, they thought the staff assumptions on loss given default (LGDs) too high in comparison with historical experience for some loan categories; and that staff had depressed the interest margin for bank earnings too much (it had remained stable so far). In addition, the authorities emphasized that average loan-to-value ratios in mortgage lending were moderate, and households were responsible for the debt not just with the property but also with their income. Thus, the loss experience in home lending had always been moderate, and more closely tied to unemployment than falling home prices.

\section{The Bank of Spain has stepped up its surveillance and the authorities are} prepared to act as needed to forestall systemic disruptions. Both off-site analysis (stress testing and liquidity monitoring) and on-site examinations have been reinforced as the authorities agreed that increased pressures will still come. In particular, supervisors share staff concern about property developers. In anticipation, they have followed a conservative approach to banks' debt-to-equity (property) swaps with ailing real estate companies, requiring the buildup of adequate capital and provision buffers.

\section{Savings banks (cajas) have regional concentration and particular exposure to} construction. NPLs in cajas are higher than for commercial banks, with some cajas in better shape than others - the staff believes that some consolidation is inevitable to keep the caja system functioning robustly, and to avoid large fiscal costs down the line. Further, and following staff's previous recommendations for more market exposure, cajas have made progress with one institution issuing participation shares in mid-2008. The downturn in the stock market has hindered further issuance, but staff recommended that they continue attempts to bolster capital, as market conditions permit. Regulations of participation shares should be simplified to make them more attractive to investors-especially regarding overly complex dividend payout rules. Further, the 2006 FSAP had recommended allowing cajas to issue capital instruments with voting rights, and eliminating the requirement for regional governments to approve mergers of cajas (Table 4). The authorities said that they do not perceive these elements as major stumbling blocks today, and would focus on immediate needs. They noted that discussions on consolidation were indeed underway and this would continue as the operating environment weakened, thus facilitating interregional mergers. Representatives of cajas explained that these had never caused a systemic disturbance and that no caja has ever failed, even though weaker ones have been absorbed through mergers.

\section{Santander and BBVA are international players and could face some risks from}

abroad. Their profits have remained high so far, and they noted that their global diversification, focused on relatively safe traditional retail banking, has been an element of strength, rather than weakness. Still, bank representatives said that Mexico, Brazil, and Chile are key markets for them, each with their own pressure points, to which they were responding with dedicated adjustments. Santander has taken advantage of the crisis to expand its retail banking model in the US and UK - it is now cutting costs in these ventures to improve profitability and reduce risks. In November, at the height of the crisis, Santander placed $€ 7.2$ billion in new shares to bolster its Tier 1 capital base, without government assistance. Likewise, BBVA, which has been less aggressive in expanding its capacity, has placed over 
$€ 1$ billion in preferred shares in December, and a similar amount in bonds in early January, also without government assistance. Both banks were hit by the Madoff scandal, but direct exposures are small. The authorities said that they were closely monitoring potential spillovers from foreign markets into Spain via the large banks through close cross-border cooperation with EU, US, and Latin-American supervisors (Figure 12).

\section{Fiscal Policy}

\section{Short run}

31. The fiscal accounts have weakened sharply with several factors contributinghitherto overestimating the structural balance is among them. Since 2001, primary spending has outpaced potential growth. Moreover, the housing boom created the impression of a permanent strong tax base. With falling house prices and less homebuilding, revenues will drop, including for local governments. Also, the ongoing rebalancing from domestic to export demand will moderate the tax base.

\section{For 2008-09, the authorities have taken measures of $\mathbf{4}$ percent of GDP so far.}

The last package, designed as part of the joint EU stimulus for 2009, is valued at 1.1 percent of GDP. It focuses on labor-intensive local public works, assistance to the automobile industry, and smaller measures. This impulse adds to the elimination of the wealth tax ( 0.2 percent of GDP) effective from 2009. In staff's view, the measures have been largely cyclical (supporting demand), without being used as a lever to reform labor and product markets, or to ease long-run structural fiscal pressures to anchor better expectations ( $₫$ 38-39; Section D). Adding discretionary fiscal measures and automatic stabilizers, the staff projects the fiscal surplus of 2.2 percent of GDP in 2007 to turn to a headline deficit of 6.1 percent, and a structural deficit of 5.2 percent, in 2009 (Table 5).

Spain: Main Fiscal Measures (Percent of GDP)

\begin{tabular}{lrr}
\hline & 2008 & 2009 \\
\hline$€ 400$ PIT cut & -0.5 & -0.1 \\
Child support (cheque bebe) & -0.1 & \\
2007 PIT reform & -0.3 & \\
2007 CIT reform & -0.5 & \\
PIT bracket non-adjustment & & 0.1 \\
Wealth tax & & -0.2 \\
Public works & -0.2 & -0.8 \\
ALMPs & & -0.1 \\
Primary current spending pressures & -0.6 & 0.0 \\
Other (incl tax base effects) & $\underline{-0.9}$ & $\underline{0.0}$ \\
$\quad$ Total & -3.1 & -1.0 \\
\hline
\end{tabular}

\section{The authorities estimate a smaller structural deficit than staff, partly because}

they have higher potential growth. ${ }^{7}$ They pointed out that measures had been designed to drop out of spending once the recession fades - an exit-strategy. Staff agreed that the structural balance would decline again in the medium run if the spending boost is temporary

\footnotetext{
${ }^{7}$ As noted in $\uparrow 15$, the authorities see more favorable demographic prospects (including with continued immigration), potential for productivity recovery, and competitiveness.
} 
Figure 12. Spain: Santander and BBVA

Their share prices have tumbled by $40-50$ percent since early 2007 .
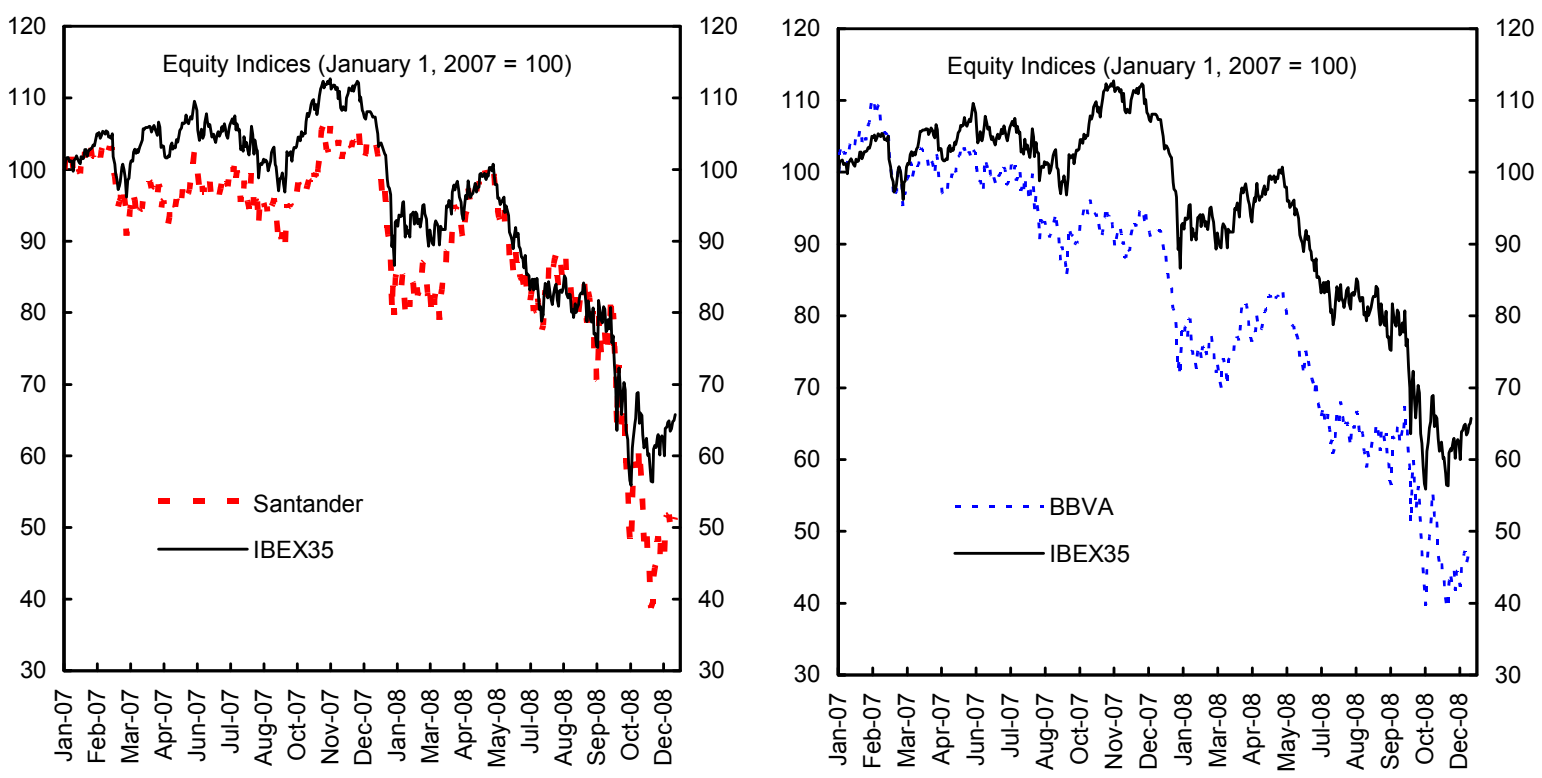

Their CDS spreads have increased in line with peers.
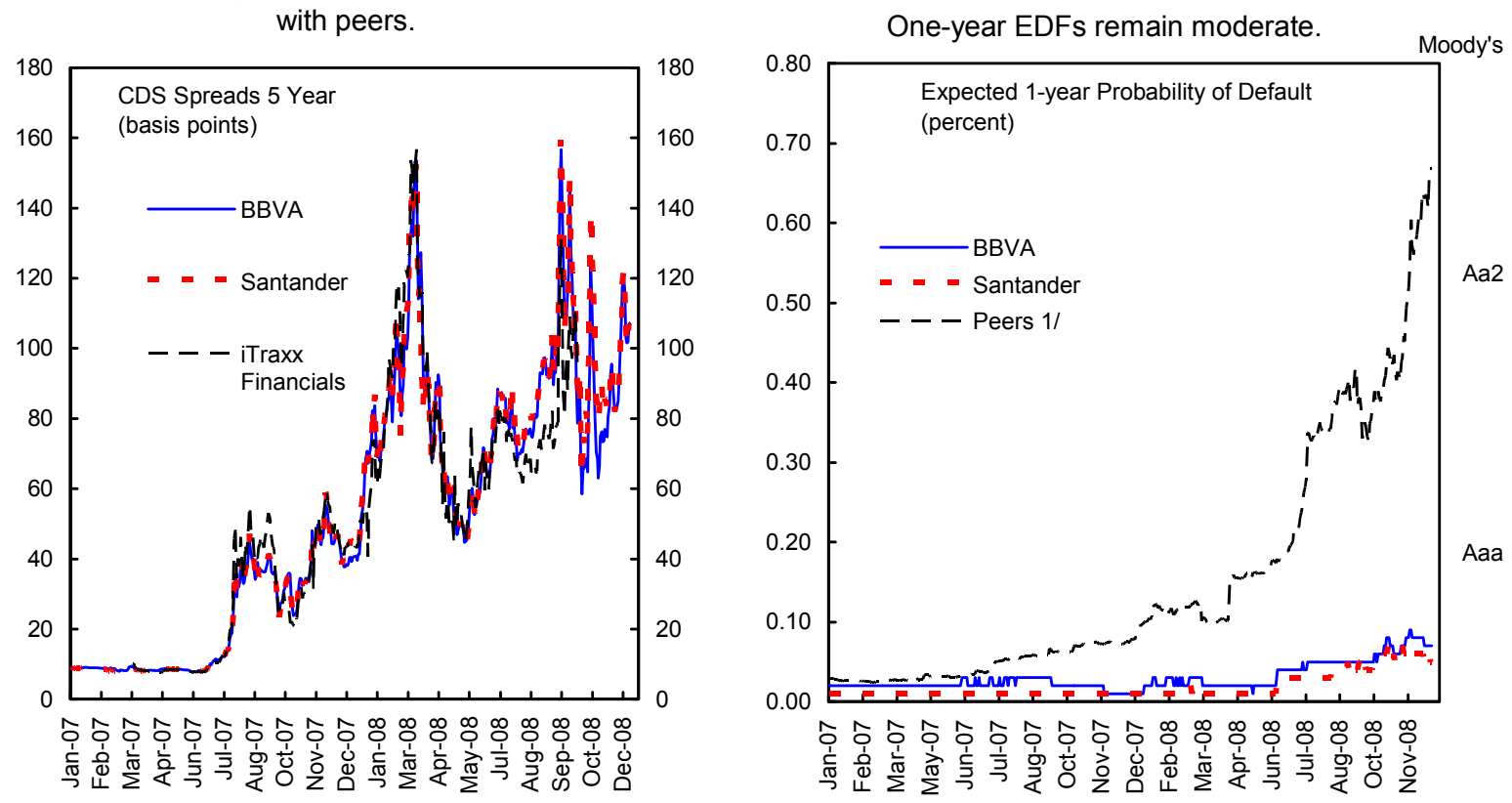

Sources: Bloomberg; National authorities; Bank of Spain; and ECB

1/ Average of Unicredito, Commerzbank, HSBC, ING, BNP Paribas. 
and no follow-up (maintenance) is required. In 2007, Spain legislated a fiscal rule that requires a surplus if growth exceeds 3 percent and permits a small deficit when growth is below 2 percent. Under current conditions, however, the authorities agreed that the fiscal balance would swing into large deficits, exceeding the SGP limits. Both domestic and SGP rules would require lowering the fiscal deficit in the future.

34. There was considerable soul-searching how to proceed with fiscal policy in 2009 if growth were to deteriorate further. There are three sets of views, including among the authorities. First, those that express puzzlement at further pressure, including from the Fund, for even larger deficits. They note that Spain has been living beyond its means and adjustment is necessary. Second, those considering that supporting the economy was appropriate but that Spain has done enough. Third, those supporting additional measures if the downturn worsens. Staff said that the circumstances were unusual and the large response by Spain had been warranted so far to avoid a standstill.

\section{Proceeding, the authorities would first give the approved measures a chance to} generate their full impact. If more measures were necessary, they would consider transfers to poor and liquidity-constrained families with high spending propensities (such as extending unemployment support, welfare) and labor-intensive infrastructure spending to protect employment. Fiscal multipliers so far had been low with resources (tax cuts) used by the private sector for deleveraging, instead of spending. The authorities would endeavor to keep measures timely and targeted, within a coordinated response with EU partners. Staff agreed that while allowing automatic stabilizers to operate fully, fiscal policy needed to remain cautious given that some fiscal powder also should be kept dry, as a contingency, to assist banks with capital, if needed. If still lower growth materializes and the authorities decided that further fiscal support were needed, staff stressed that this should be combined with long-run fiscal, labor (such as agreeing with social partners on a program of wage moderation and labor market liberalization), and product market reforms. This would help start a new growth cycle with improved competitiveness and higher productivity to avoid a potential L-shaped stagnation.

36. In addition to the above-the-line measures, the authorities have taken below-the-line measures to support housing, SMEs, and banks. The fully government-guaranteed Official Credit Institute (ICO) and the Treasury have granted credit lines and guarantees providing up to 4.9 percent of GDP in liquidity support through end-2009 (additional to the deficit). The many extensions to its programs are challenging ICO, which is small. Room to do more is limited if implementation is to remain of high quality. Funding assistance to banks (FAAF and debt guarantees) is potentially large at 22.8 percent of GDP, if fully employed. 
Spain: ICO Credit Lines -- 2008 and 2009

(Percent of GDP)

\begin{tabular}{lrr}
\hline & 2008 & 2009 \\
\hline Plan RENOVE and VIVE & & 0.3 \\
SMEs & 0.9 & 2.6 \\
Stimulate rental housing & & 0.3 \\
$\quad$ Total & 0.9 & 3.1 \\
\hline
\end{tabular}

Spain: ICO and Government Guarantees

(Percent of GDP)

\begin{tabular}{lrr}
\hline & 2008 & 2009 \\
\hline ICO-for social housing & 0.5 & 0.9 \\
ICO-for mortgage assistance & & 0.3 \\
SMEs-government & 0.3 & 0.5 \\
Total & 0.7 & 1.8 \\
\hline
\end{tabular}

Spain: Government Banking Assistance 2008-09 1/

(Percent of GDP)

\begin{tabular}{lrrr}
\hline & 2008 & \multicolumn{2}{c}{2009} \\
\cline { 3 - 4 } & & Spain & Euro area \\
\hline Fund/purchase financial assets & 0.9 & 4.5 & 1.8 \\
Debt guarantees & 9.1 & 18.2 & 21.0 \\
Capital injections & 0.0 & 0.0 & 2.7 \\
Total & 10.0 & 22.8 & 25.5 \\
\hline
\end{tabular}

1/ Cumulative. Euro area is GDP weighted and excludes Finland and Luxembourg.

\section{The debt implications of the fiscal measures, credit lines, and guarantees are}

large. The deficit is likely to stay elevated in the medium-term, with some improvement as spending measures drop out in future years. Nevertheless, if all support is fully used, gross debt and guaranteed debt would increase by $€ 395$ billion (34 percent of GDP) in 2007-09, and the debt ratio could rise to 74 percent of GDP. The assets backing some debts are rated AAA and AA, so potential losses were deemed small. Further, sunset clauses imply that the guaranteed debt will fall quickly once the programs end, but staff felt that risk exposure, given the weak economy, should not be downplayed. The sovereign spread over 10 year Bunds has already increased from 7 to over $100 \mathrm{bp}$, and Spain's long-run AAA sovereign debt rating has been downgraded one notch by one rating agency, so caution is warranted.

\section{Long run}

\section{The authorities agreed that current economic policies do not secure long-run}

fiscal sustainability. The authorities' medium-term potential growth projections (around 3 percent a year) are higher than those of staff ( 2 percent a year), but similar beyond the next decade. Spain faces growing dependency ratios, lower labor input, and slowing output growth rates in the future. Immigration is more buoyant in the authorities' medium-term projections, which would push out into the future the effects of aging on growth and the fiscal position - a delay, not a solution of eventual pressure. In the staff's long-run framework (Figure 13), and assuming a productivity recovery from low levels, potential growth could remain around 2 percent for some time before demographic slowing kicks in. Spain has one of the highest aging costs among advanced countries and those in the EU Aging Working Group. Using 
Figure 13. Spain--Demographic Indicators and Assumptions

Unlike the EU25, the Spanish population is projected to continue growing for some time...

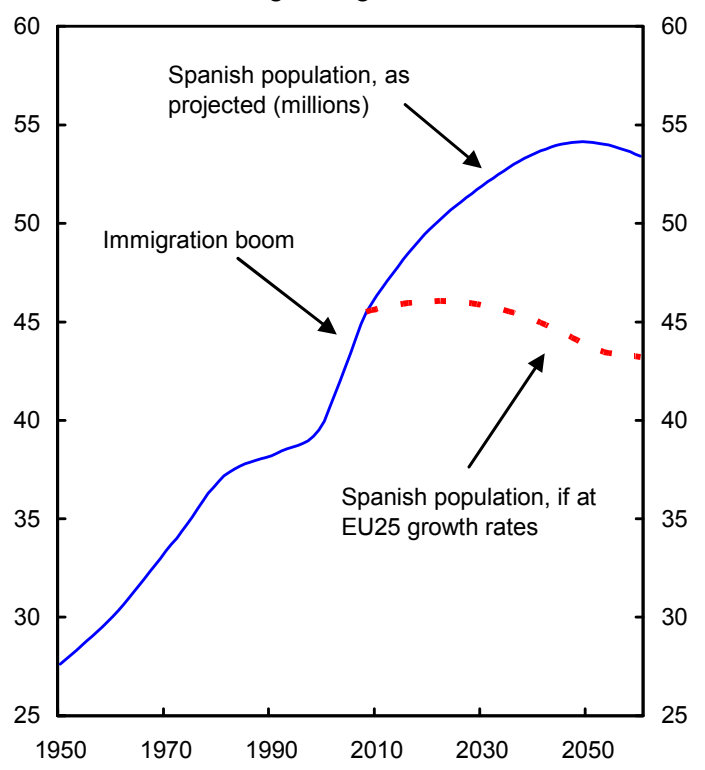

As a result, the dependency ratio will rise.

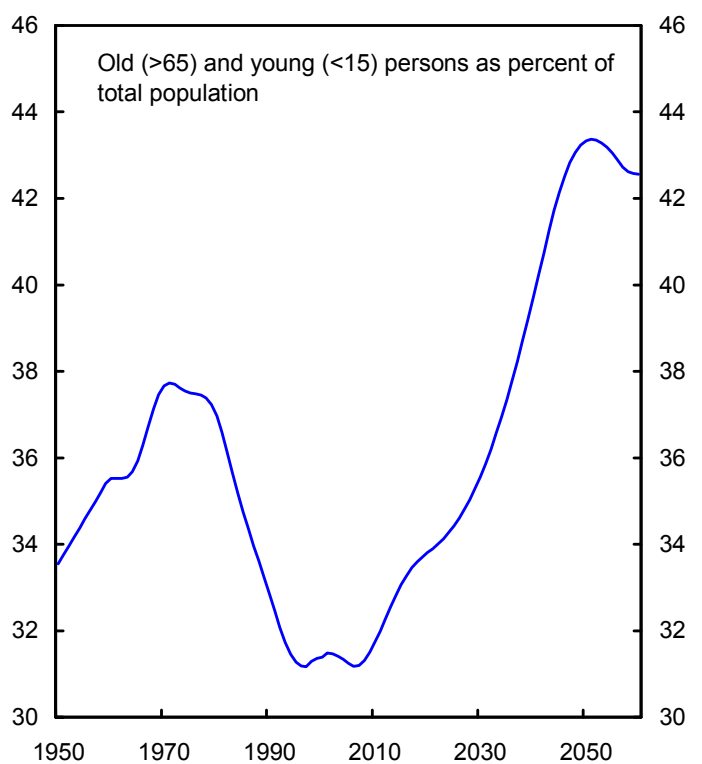

...but aging will significantly slow the growth of the working age population.

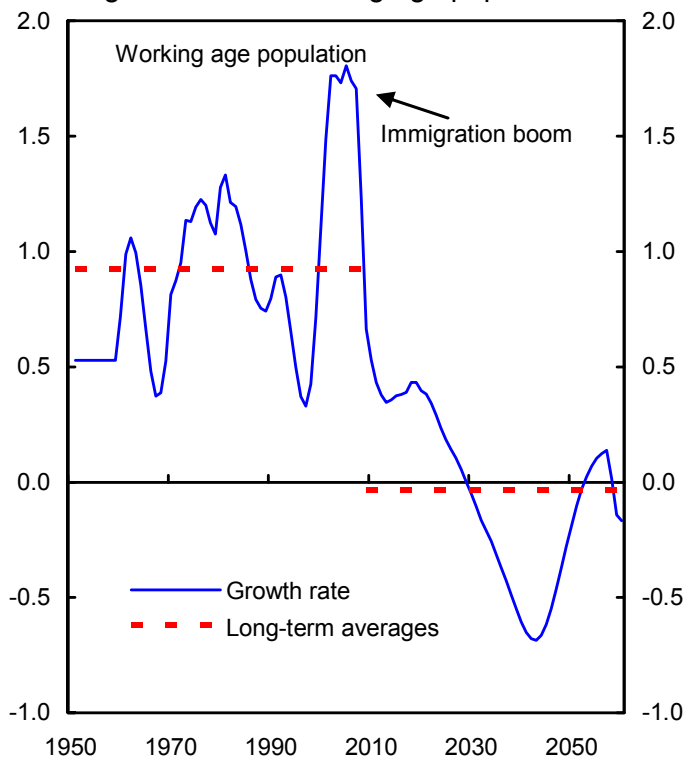

The IMF staff assume that participation will increase further.

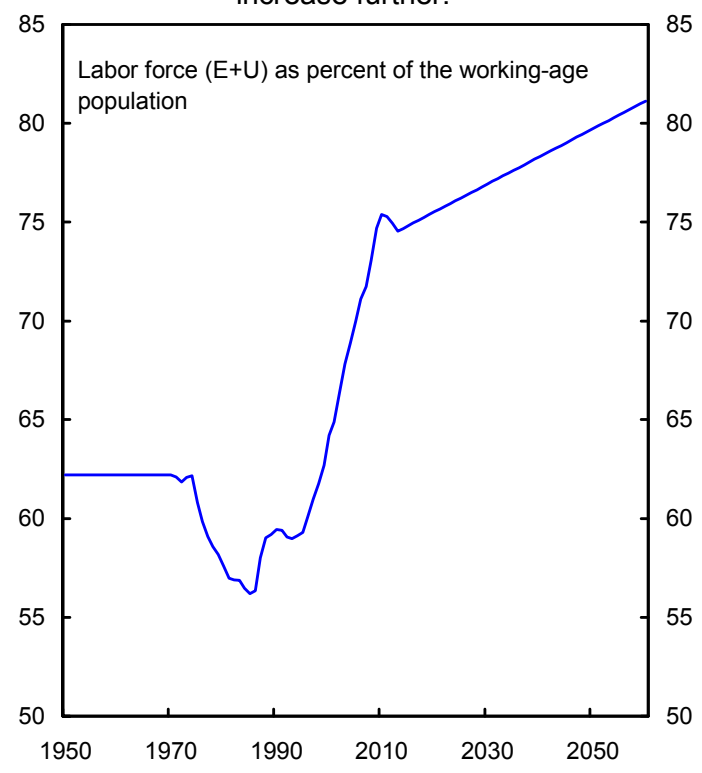

Source: IMF staff projections based on data provided by the authorities. 
these data, the staff's long-run projections find unsustainable debt dynamics with current policies (Figure 14). ${ }^{8}$

Spain: Staff Baseline Scenario for Long-Run Potential Real GDP 1/

\begin{tabular}{|c|c|c|c|c|c|c|c|c|c|}
\hline & \multicolumn{3}{|c|}{ Actual } & \multicolumn{6}{|c|}{ Projection } \\
\hline & 1970-79 & 1980-89 & 1990-99 & $2000-09$ & 2010-19 & $2020-29$ & 2030-39 & $2040-49$ & $2050-60$ \\
\hline Real GDP & 3.7 & 2.7 & 2.7 & 2.8 & 1.9 & 2.1 & 1.5 & 1.1 & 1.7 \\
\hline Labor productivity (per hour worked) & 3.7 & 2.3 & 1.0 & 0.1 & 0.8 & 1.5 & 1.5 & 1.5 & 1.5 \\
\hline Total hours worked & 0.0 & 0.4 & 1.7 & 2.7 & 1.1 & 0.7 & 0.0 & -0.4 & 0.2 \\
\hline Hours worked per employed person & 0.0 & 0.0 & 0.2 & -0.3 & 0.0 & 0.0 & 0.0 & 0.0 & 0.0 \\
\hline Employed persons & 0.0 & 0.4 & 1.6 & 3.1 & 1.1 & 0.7 & 0.0 & -0.4 & 0.2 \\
\hline Working-age population & 1.1 & 1.0 & 0.6 & 1.5 & 0.4 & 0.2 & -0.3 & -0.6 & 0.0 \\
\hline LF participation rate & -0.4 & 0.1 & 0.3 & 1.2 & 0.1 & 0.1 & 0.1 & 0.1 & 0.1 \\
\hline Employment rate & -0.6 & -0.4 & 0.5 & 0.9 & 0.4 & 0.3 & 0.2 & 0.1 & 0.1 \\
\hline \multicolumn{10}{|l|}{ Memorandum items: } \\
\hline Population & 1.0 & 0.4 & 0.4 & 1.5 & 0.7 & 0.5 & 0.3 & 0.1 & -0.1 \\
\hline Employment growth & 0.0 & 0.4 & 1.6 & 3.1 & 1.1 & 0.7 & 0.0 & -0.4 & 0.2 \\
\hline Unemployment rate & 5.2 & 17.1 & 17.9 & 10.9 & 14.2 & 8.7 & 7.6 & 7.0 & 7.0 \\
\hline
\end{tabular}

Spain: Aging Costs 1/

\begin{tabular}{lccr}
\hline & 2004 & 2030 & 2050 \\
\hline & \multicolumn{3}{c}{ (Percent of GDP) } \\
Total & 19.9 & 22.3 & 28.3 \\
Pensions & 8.5 & 10.8 & 15.5 \\
Health care & 6.1 & 7.3 & 8.3 \\
Long-term care & 0.5 & 0.5 & 0.7 \\
Unemployment benefits & 1.1 & 0.7 & 0.7 \\
Education & 3.7 & 3.0 & 3.1 \\
& (Change from 2004) & \\
Total & & 2.4 & 8.4 \\
Pensions & & 2.3 & 7.0 \\
Health care & & 1.2 & 2.2 \\
Long-term care & & 0.0 & 0.2 \\
Unemployment benefits & & -0.4 & -0.4 \\
Education & & -0.7 & -0.6 \\
\hline
\end{tabular}

Source: Ministry of Economy and Finance.

$1 /$ Increase in age-related spending through 2050.
Spain: Cross-Country Comparison of Aging Burden 1/

\begin{tabular}{lr}
\hline & (Percent of GDP) \\
Canada & 726 \\
Korea & 683 \\
Spain & $\underline{652}$ \\
United States & 495 \\
Australia & 482 \\
United Kingdom & 335 \\
Germany & 280 \\
France & 276 \\
Mexico & 261 \\
Turkey & 204 \\
Italy & 169 \\
Japan & 158 \\
Advanced countries & 398 \\
\hline
\end{tabular}

Source: IMF, Fiscal Affairs Department.

$1 /$ Net present value of long-run age-related spending.

\section{Staff recommended publishing an intertemporal public sector balance sheet as} part of the annual budget document to frame policies in a long run context. The balance sheet would reflect current assets and liabilities and the NPV of future primary balances, including aging costs, based on current policies. Staff calculations suggest that in 2007 Spain's public sector net worth was -40 percent of GDP. However, with the large downshift in the structural primary balance, the path of future primary balances significantly worsened, leading net worth to drop to -147 percent of GDP in 2009 (even after clawing back some expenditures in the medium term) (Table 6). Seen in this context, Spain has no fiscal space for expansion, unless the authorities can commit to adjustments (parametric pension and health reforms; extending retirement ages; limiting benefit indexation for the wealthiest; a

\footnotetext{
${ }^{8}$ The background paper on long run fiscal sustainability elaborates on these themes.
} 
Figure 14. Spain--Long-Run Macroeconomic Scenario and Public Debt Sustainability (Annual percent change, unless otherwise indicated)

Long-run growth is projected to ease as the working - age population slows.

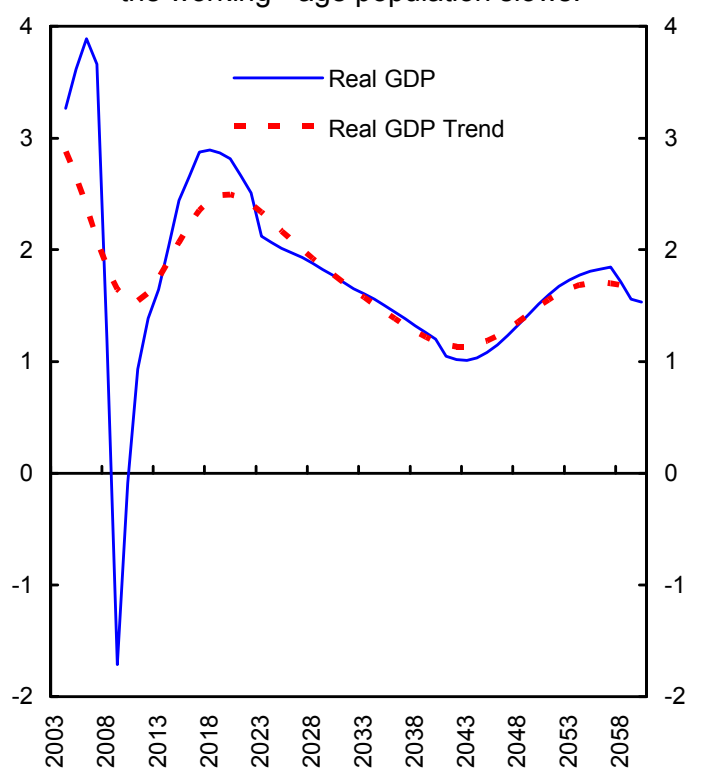

Real interest rates move in line with growth. 1/

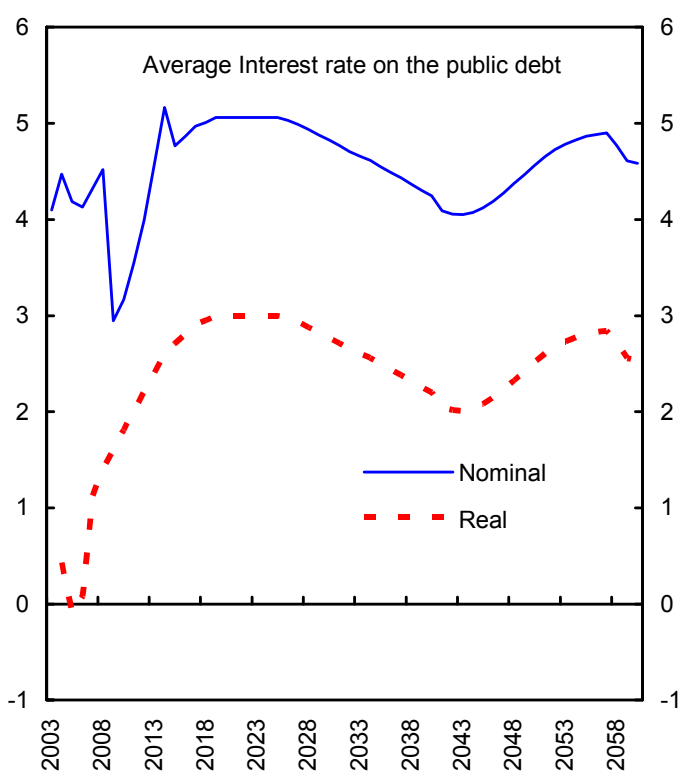

Source: IMF staff calculations.

$1 /$ Assumes real interest rate $=$ real GDP growth $+100 \mathrm{bp}$.
We assume that Spain will meet the ECB inflation target.

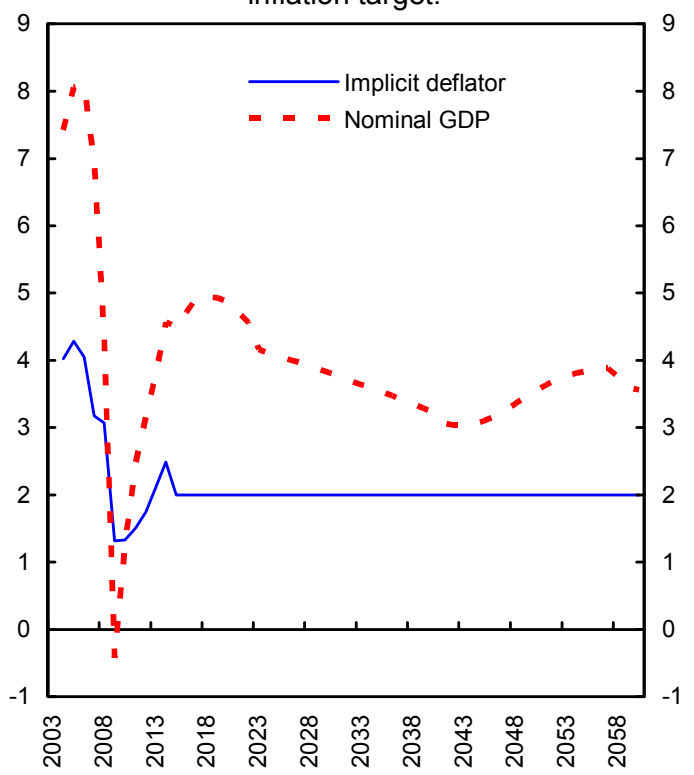

Under current fiscal policies, debt dynamics are far from sustainable.

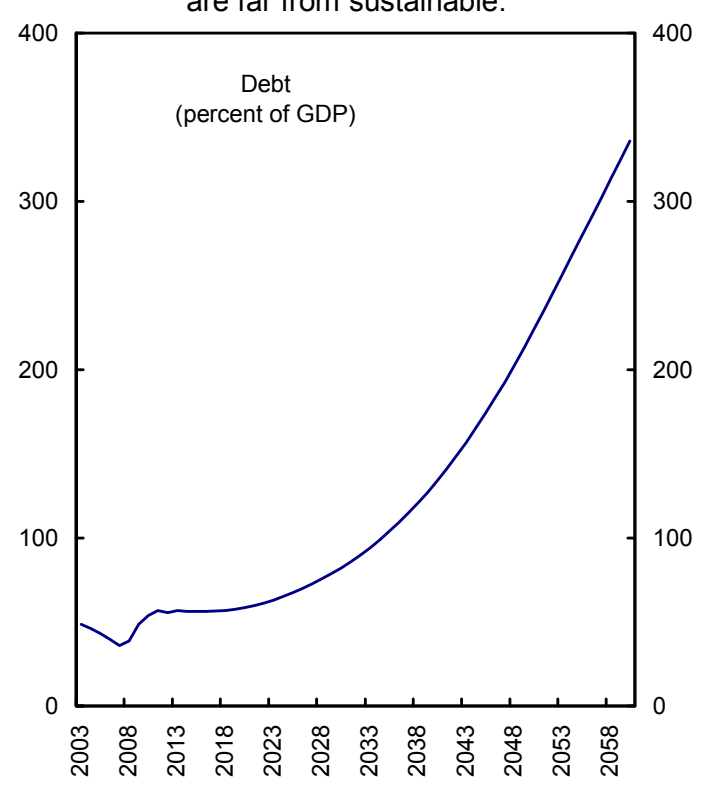


combination of progressive income tax increases and expenditure cuts in the non-aging related budgets, including phasing out the mortgage interest deduction) that bolster the public balance sheet. The authorities agreed that further steps in pension reform were necessary and that plans to this effect were being developed in cooperation with social partners. Staff felt that this effort might require a firmer push by the authorities.

\section{Competitiveness and Structural Reforms}

40. Indicators suggest a competitiveness gap. Measures based on relative consumer prices and unit labor costs point to an appreciation of 12-21 percent over Spain's long-run averages. Additional staff estimates based on the CGER methodologies indicate a gap of 11-22 percent. $^{9}$ These findings signal impaired competitiveness (Figure 15).

41. Under currency union, improving competitiveness will take time. Instead of repressing demand, it is preferable to implement labor and product market reforms to cut costs and reallocate resources to more productive use for a vigorous recovery. The authorities pointed out that some restructuring has taken place over the last decade as indicated by the technological upgrade of exports and increasing specialization in high value-added services. ${ }^{10}$ Nevertheless, they agreed that rapid import penetration points to some lack of competitiveness in domestic markets (Tables 7 and 8).

42. Ambitious labor and output market reforms need to be implemented jointly to avoid income shifts, while accruing benefits through improved productivity and lower costs. Labor reforms should focus on reducing wage indexation, which is inconsistent with currency union, and propagates adverse shocks to wages. Reducing labor market segmentation would allow better trained young cohorts to flow more quickly from fixed-term to better-paid permanent jobs, thereby increasing returns to higher education (which are low). Staff also recommended allowing opt-out clauses in collective labor agreements to be invoked earlier than is now the case, because many companies cannot recover once they get close to bankruptcy resulting in a loss of all jobs (Figure 16).

\section{The authorities were circumspect on ambitious macroeconomic labor reforms} without stronger support from social partners. Instead, they seek more microeconomic adjustments with the aim to reduce unit labor costs by boosting productivity (denominator) rather than wage moderation (numerator). The labor ministry favors improved job intermediation, including with private firms, and boosting the effectiveness of active labor market policies. Also, Spain wants to improve education, where test scores are below the EU average and dropout rates are high. Staff welcomed these efforts, but noted that they would require time to take effect and seemed almost peripheral to the competitiveness and

\footnotetext{
${ }^{9}$ The authorities noted their reservations about CGER type estimates, given statistical and methodological uncertainties of these estimates.

${ }^{10}$ See country report No $08 / 145$.
} 
Figure 15. Spain--Competitiveness Indicators

\begin{tabular}{lc}
\multicolumn{2}{c}{$\begin{array}{c}\text { Estimates of Competitiveness Gap 1/ } \\
\text { (percent) }\end{array}$} \\
\hline
\end{tabular}

REER based on the CPI is well over its LR average...

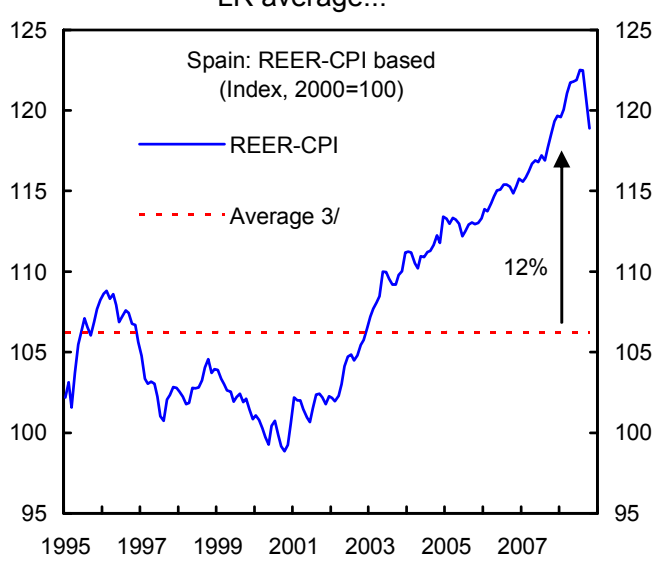

Spanish exports have held their own...

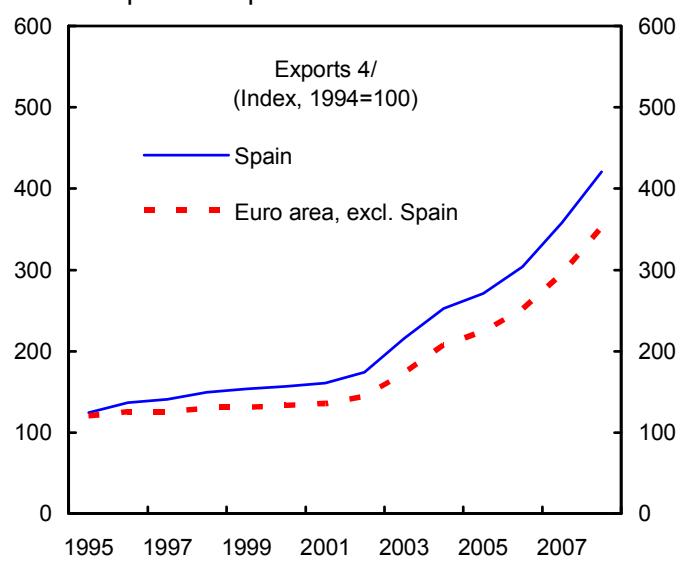

...even more so based on ULCs.

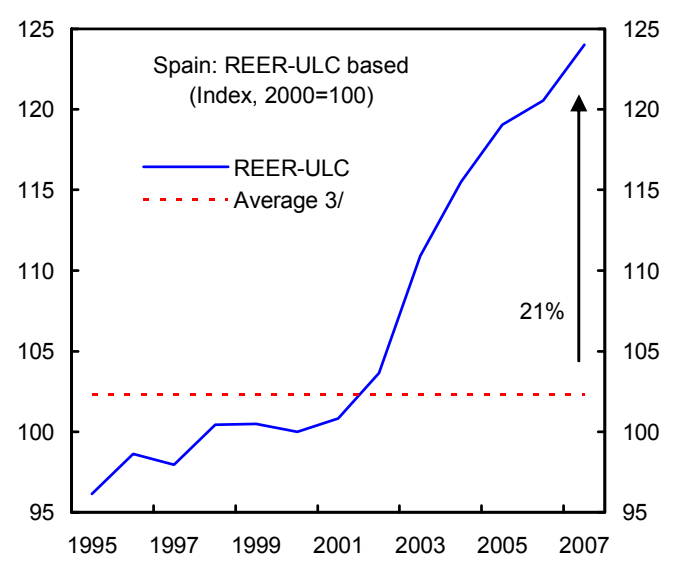

...but imports have been booming.

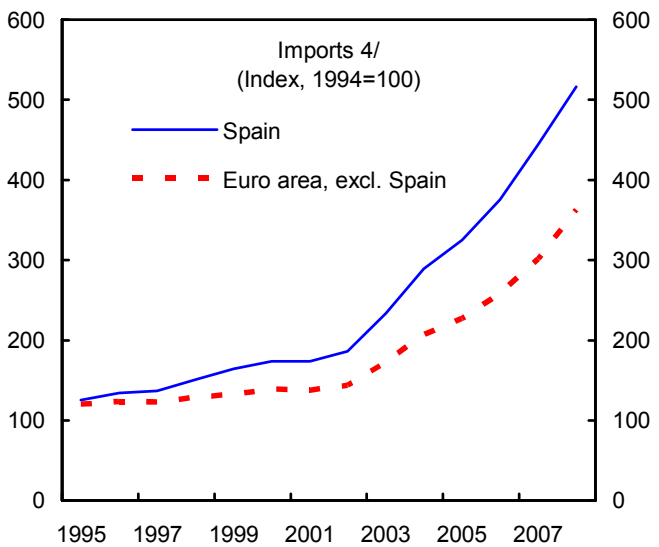

Sources: CGER; IMF-INS; and WEO.

$1 /$ Given the large negative output gap over the medium term, staff have taken 2009 as the reference year for the calculations.

The competitiveness gap may be underestimated to the the extent that it does not include the effect of recent REER

appreciation.

2/ Excluding the effect of euro entry.

3/ Average from 1980.

4/ Index of exports and imports of goods and services in current U.S. dollars. 
Figure 16. Spain--Labor Market Issues

Temporary employment is prevalent to pre-empt high dismissal costs.

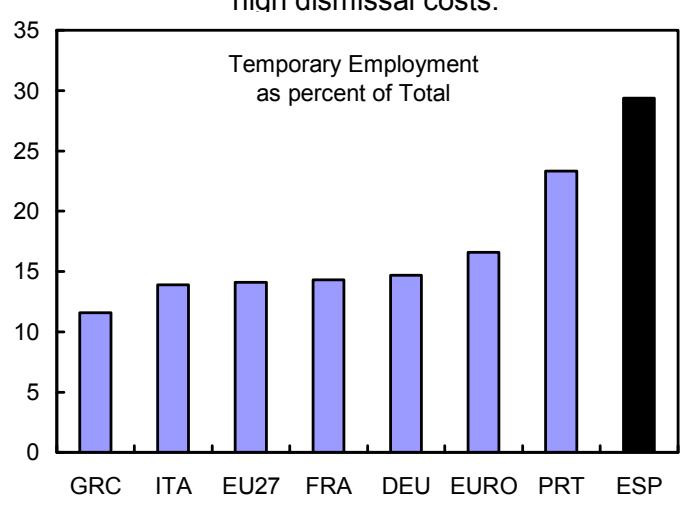

...and regional wage differentiation is small, even though unemployment differs widely.

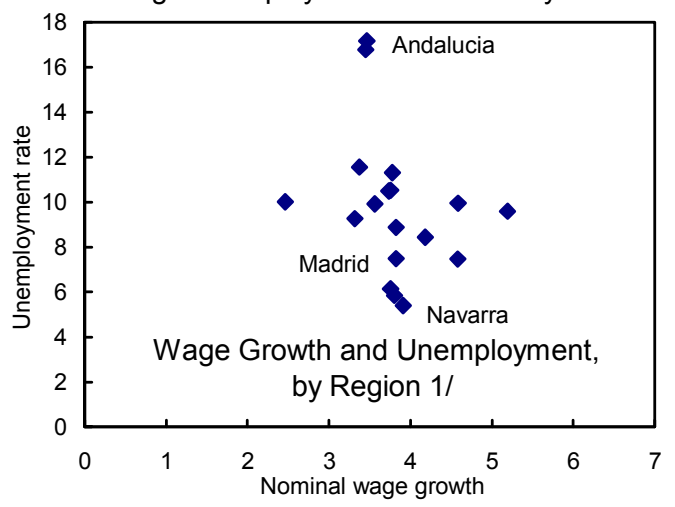

Returns to education are low, suggesting the labor market allocates poorly.
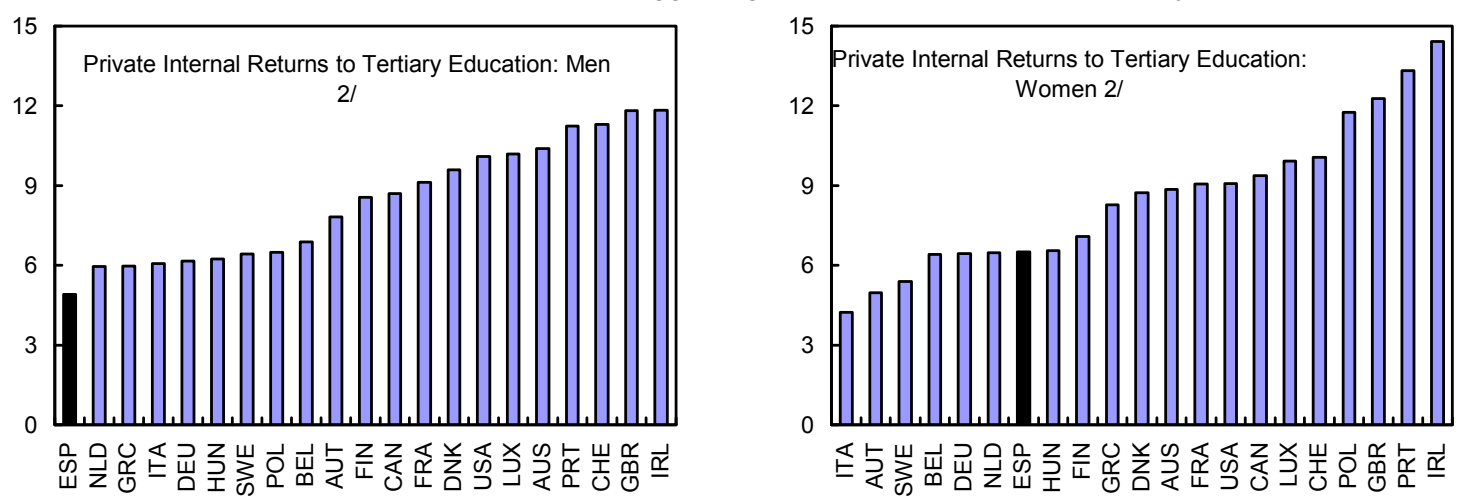

Drop-out rates are high; PISA Scores are below EU average - contributing to low productivity, but younger cohorts are better educated.

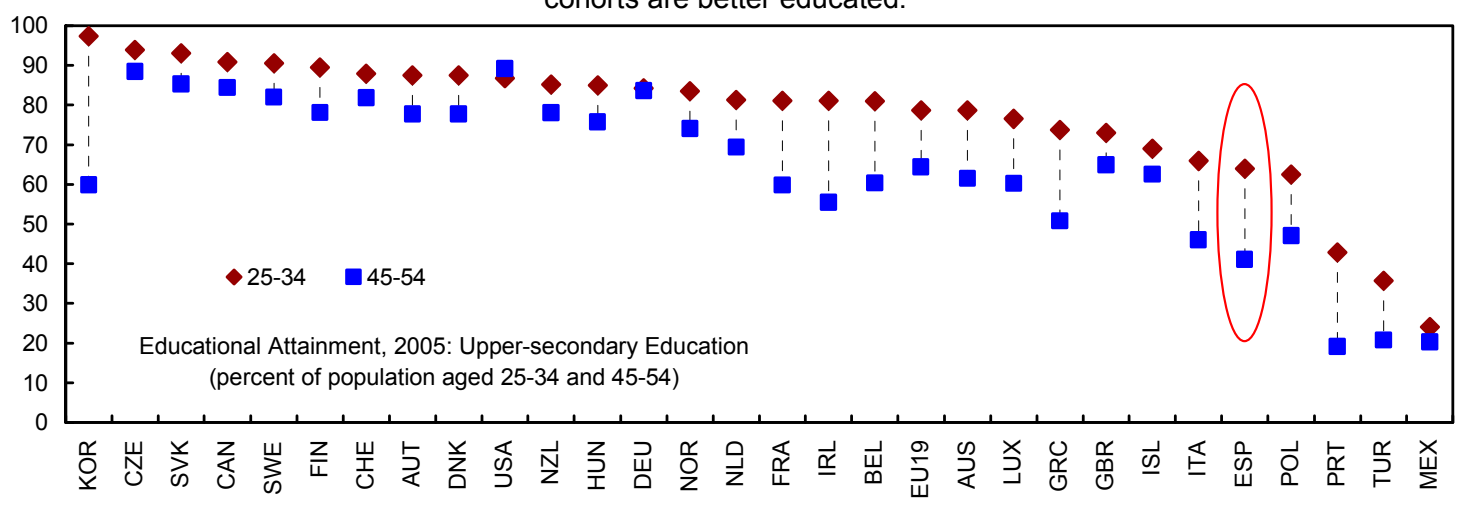

Sources: OECD; and EU Commission

$1 /$ Average for 2000-2007.

2/ Rates of return associated with tertiary education, in percent a year, adjusted for taxation. 
unemployment challenge at hand. In staff's view, Spain needs urgent wage moderation to lower costs, for which, however, there is no consensus.

44. The authorities are proceeding with product market reforms. Product market reforms seek to transpose the Services Directive, ${ }^{11}$ reduce administrative burdens, improve competition in professional services, and reform network industries (Figures 17-18). ${ }^{12}$ Well-entrenched groups are opposing parts of these reforms, so striving for an ambitious rather than piecemeal implementation is crucial.

Spain: Structural Reform Needs

Labor Market

- $\quad$ Cut wage indexation to reduce the inflation differential with the euro area.

- Invoke opt-out clauses earlier in collective wage bargaining agreements to preserve jobs and prevent companies from declaring bankruptcy.

- $\quad$ Equalize dismissal costs of temporary and permanent contracts at a low level to reduce segmentation.

Goods and Services Markets

- Liberalize services through an ambitious transposition of the European Services Directive. Regional authorities need to ensure effective implementation

- $\quad$ Eliminate restrictions to competition in professional services.

- $\quad$ Reform network industries to improve competition. Electricity prices should recover costs in contested and unbundled markets.

- $\quad$ Reduce administrative burdens.

\section{Staff Appraisal}

45. After 15 years of impressive growth led by a housing boom, a sharp correction of accumulated imbalances is underway. The challenge is major: with construction activity collapsing, banks under pressure, foreign demand faltering, and competitiveness weak, Spain needs both cyclical support and substantial reforms. The authorities' response has been forceful in banking and fiscal policies, but they also need to bolster competitiveness to avoid getting stuck in a slow-growth/high-unemployment equilibrium, from which lowering public debt would be difficult.

\footnotetext{
${ }^{11}$ Using a general equilibrium model, the authorities calculate that an ambitious implementation of the Services Directive could reduce margins by an average of $33 / 4$ percent and lift potential GDP by $1 \frac{1}{4}$ percent - in the steady state and compared with a no-reform scenario. Separately, simulations with a sectoral labor productivity growth model performed by the OECD suggests that productivity growth could increase by close to 1 percent in Spain, if it were to adopt product market regulations equal to those of less restrictive countries

${ }^{12}$ The background paper on productivity growth elaborates these measures.
} 
Figure 17. Spain--Productivity Indicators

Factors explaining the inflation differential with the Euro Area

(contributions to inflation differential, percentage points) 1/

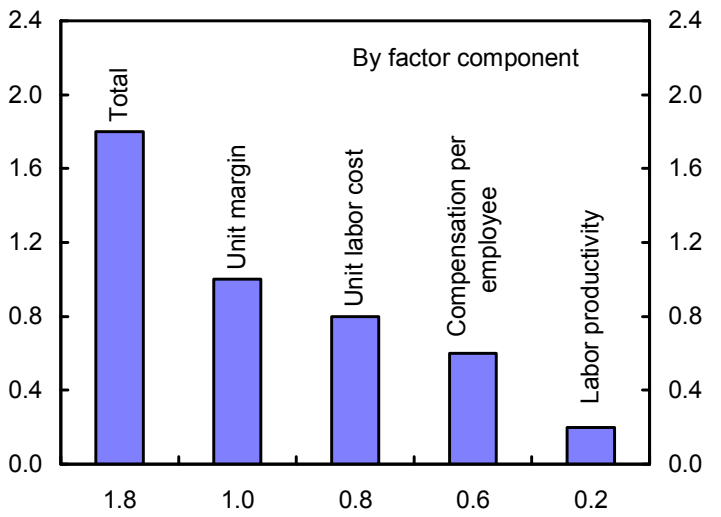

Productivity growth has fallen behind the EU...

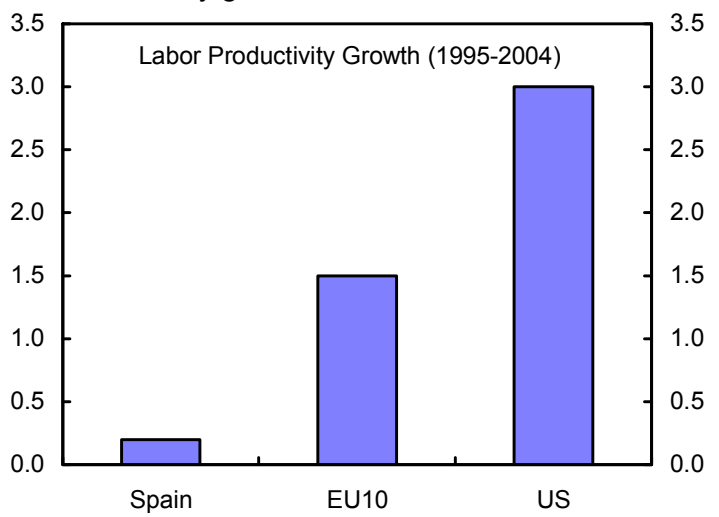

Post, telecom, transport, and retail are poor TFP performers.

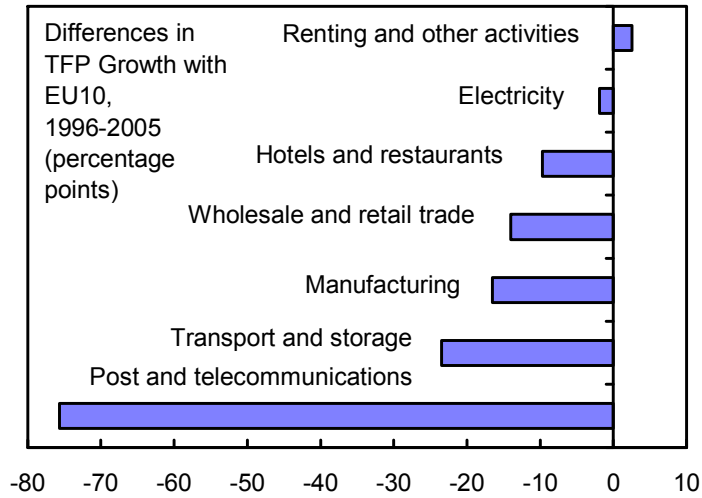

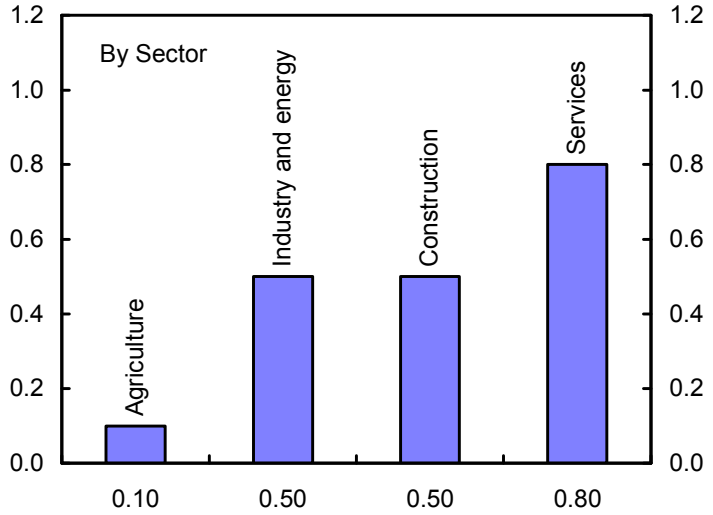

...with Construction faring the worst.

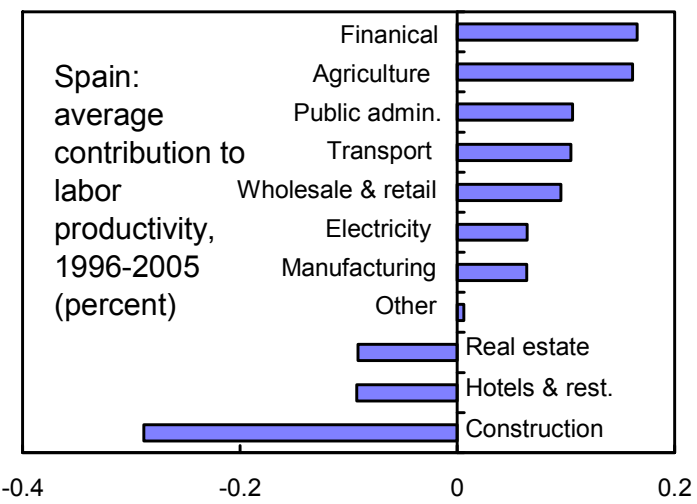

Barriers to entry hamper firm formation and innovation.

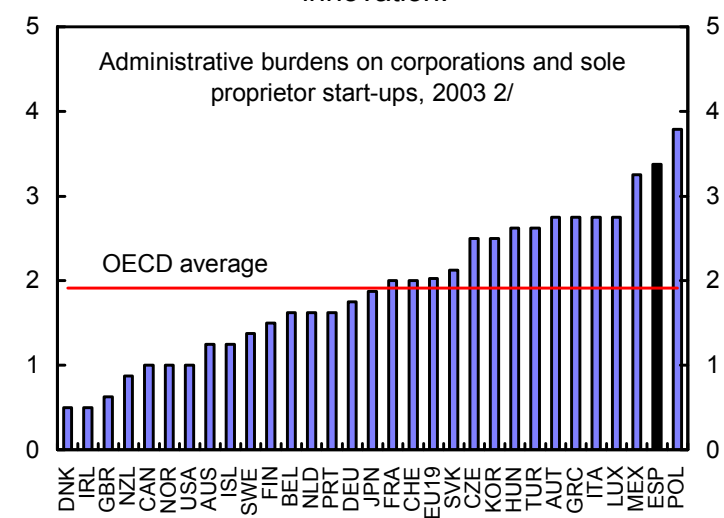

Sources: Van Ark et al. (2008); OECD; Bank of Spain; and EU Klems database.

1/ Using the GDP deflator; 2002-2007 average.

2/ Index scale of 0-6 from least to most restrictive. 
Figure 18. Product Market Regulation, 2003 1/

Product market restrictions are at or above those of the OECD average.
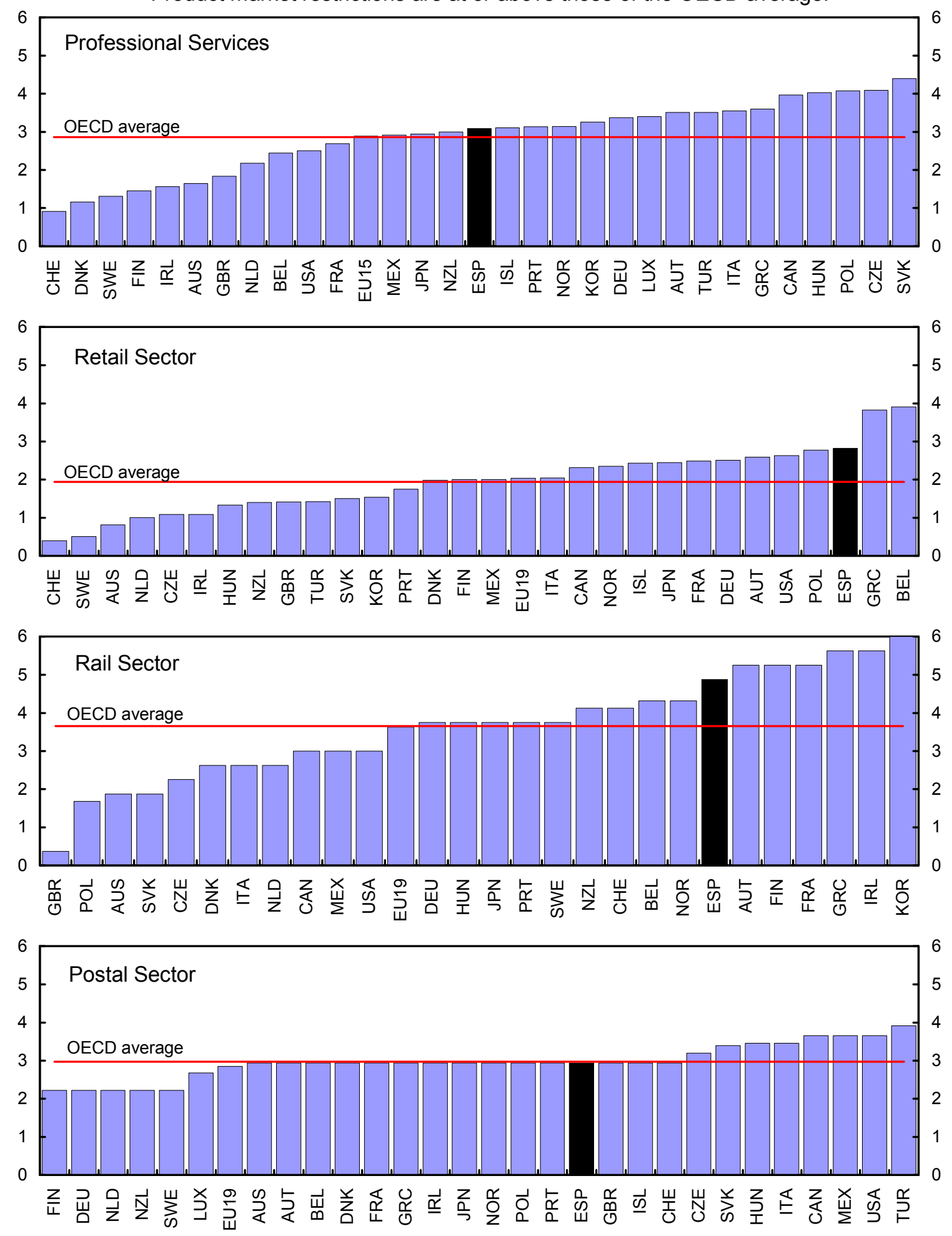

Source: OECD, Going for growth 2008.

$1 /$ Index scale of 0-6 from least to most restrictive. 
46. Indicators suggest a substantial downturn in 2009, driven by deleveraging and external weakness. High private debt and weak external competitiveness cause long adjustments. Spain cannot devalue the currency to bolster competitiveness, so reforms that cut costs and improve productivity are key. Because risks are on the downside, contingency planning should include a worse-case scenario of even weaker growth, while specifying how to secure fiscal sustainability (a V-shape for the fiscal balance).

47. The housing sector correction is underway but will take time. New homes are still coming on the market, pressuring home prices. Policies to activate the rental market are welcome. Mortgage assistance to newly unemployed workers can help limit foreclosures. Building more subsidized homes, however, is inadvisable as it adds to inventory and does not always benefit those intended.

48. Banks have held up well so far, including with timely government assistance. Dynamic provisioning and rigorous treatment of off-balance sheet vehicles has helped banks to absorb the first blows of the crisis. Now, NPLs are increasing rapidly and high reliance on wholesale markets makes funding the Achilles' heel of the banking system. The measures to assist funding (FAAF and bank debt guarantees) are large, have appropriate sunset clauses, and their pricing is agreed with EU partners. Banks need to allocate credit without political interference.

49. However, banks' operating environment will become even more challenging and the authorities need to be vigilant and prepare to act. Dislocated wholesale markets, higher funding costs, deteriorating asset quality, slowing lending growth, and higher capitalization demanded by markets weigh on the outlook, and consolidation is highly likely. As a contingency, the authorities have established legal provisions to support banks with capital assistance, but they wish to use market-based solutions to the extent possible and to avoid distortions, which the staff supports. Nevertheless, capital injections should be used if systemic pressures arise.

50. Cajas and the two large banks have special characteristics and needs. Cajas high dependence on local real estate activity creates vulnerability and staff believes that some consolidation would be helpful. Indeed, more political acceptance of interregional mergers would keep them healthy and in service to their communities. Further, cajas are encouraged to issue more participating capital shares as conditions permit. For the two large banks, their resilience has been impressive; they have strong, diversified retail franchises, but even they got caught off guard by unforeseen events, so there is no room for complacency. Tight cooperation with EU, US, and Latin-American supervisors remains crucial

51. Fiscal policies have been bold but should seek bigger reform leverage. The large structural measures, together with automatic stabilizers, have resulted in a sharply weaker fiscal position. The shortcoming of the measures is that they have not achieved structural reforms to increase growth potential and thus ward off the possibility of an L-shaped 
stagnation. Further fiscal impulse - only if necessary, and in cooperation with EU partners, or to assist banks - should be linked to structural reforms, to minimize their social costs.

\section{Fiscal policies need to be embedded in a long-run context to explain how policies}

can be made sustainable. This could strengthen confidence and is important to avoid private agents from turning Ricardian and to limit the increase in risk spreads. As a communication device, the authorities should publish an intertemporal public sector balance sheet in the annual budget, showing the debt already incurred, and the consequences of present policies on the stream of future deficits (a forward-looking debt). Pension and other long-term fiscal reforms are highly necessary to dampen aging costs and secure confidence in sustainability.

\section{Simultaneous product and labor market reforms require strong and full} implementation to deflate margins and lower costs. A persistent inflation differential with euro partners reflecting high margins (returns to employers) and high unit labor costs (returns to workers) has resulted in a competitiveness gap. The plans for product market reforms are well taken and in line with EU partner countries toward a unified European market for goods and services. The transposition of relevant Directives needs to be ambitious, and implemented with vigor to address the inevitable opposition from special interests. The plans for labor market reform are disappointing given the competitiveness and unemployment challenge at hand. Spain needs extended strong wage moderation and structural macroeconomic labor reforms, including the elimination of wage indexation, earlier adoption of opt-out clauses from bargaining contracts to preserve employment, and a reduction in the segmentation of labor markets between fixed-time and full-time contracts. Dismissal costs in these job market segments need to be equalized at a low level to boost hiring and mobility.

54. It is recommended that Spain remain on the 12-month Consultation cycle. 
Table 1. Spain: Main Economic Indicators

(Percent change unless otherwise indicated)

\begin{tabular}{|c|c|c|c|c|c|c|c|c|}
\hline & \multirow[b]{2}{*}{2002} & \multirow[b]{2}{*}{2003} & \multirow[b]{2}{*}{2004} & \multirow[b]{2}{*}{2005} & \multirow[b]{2}{*}{2006} & \multirow[b]{2}{*}{2007} & \multicolumn{2}{|c|}{ Projections } \\
\hline & & & & & & & 2008 & 2009 \\
\hline \multicolumn{9}{|l|}{ Demand and supply in constant prices } \\
\hline Gross domestic product & 2.7 & 3.1 & 3.3 & 3.6 & 3.9 & 3.7 & 1.2 & -1.7 \\
\hline Private consumption & 2.8 & 2.9 & 4.2 & 4.2 & 3.9 & 3.5 & 0.5 & -2.0 \\
\hline Public consumption & 4.5 & 4.8 & 6.3 & 5.5 & 4.6 & 4.9 & 5.0 & 3.4 \\
\hline Gross fixed investment & 3.4 & 5.9 & 5.1 & 7.0 & 7.1 & 5.3 & -2.1 & -15.7 \\
\hline Construction investment & 6.3 & 6.2 & 5.4 & 6.1 & 5.9 & 3.8 & -4.7 & -15.2 \\
\hline Other & -0.2 & 5.2 & 4.6 & 8.4 & 9.1 & 7.9 & 1.2 & -16.5 \\
\hline Stockbuilding (contribution to growth) & 0.0 & -0.1 & 0.0 & -0.1 & 0.2 & -0.1 & 0.0 & -0.1 \\
\hline Total domestic demand & 3.2 & 3.8 & 4.8 & 5.1 & 5.1 & 4.2 & 0.5 & -5.0 \\
\hline Net exports (contribution to growth) & -0.6 & -0.8 & -1.7 & -1.7 & -1.5 & -0.8 & 0.7 & 3.6 \\
\hline Exports of goods and services & 2.0 & 3.7 & 4.2 & 2.5 & 6.7 & 4.9 & 2.6 & -0.4 \\
\hline Imports of goods and services & 3.7 & 6.2 & 9.6 & 7.7 & 10.3 & 6.2 & -0.1 & -11.0 \\
\hline Potential output growth (long run HP-filter) & 3.3 & 3.1 & 2.9 & 2.7 & 2.4 & 2.1 & 1.8 & 1.6 \\
\hline Output gap (percent of potential) & 0.2 & 0.1 & 0.5 & 1.4 & 2.9 & 4.5 & 3.9 & 0.4 \\
\hline Non-financial private sector borrowing $1 /$ & 14.1 & 15.8 & 16.3 & 21.2 & 24.2 & 15.4 & 8.0 & $\ldots$ \\
\hline Household savings (percent of disposable income) & 11.4 & 12.0 & 11.3 & 11.3 & 11.2 & 10.2 & $\cdots$ & $\ldots$ \\
\hline \multicolumn{9}{|l|}{ Prices } \\
\hline GDP deflator & 4.3 & 4.1 & 4.0 & 4.3 & 4.0 & 3.2 & 3.1 & 1.3 \\
\hline HICP (average) & 3.6 & 3.1 & 3.1 & 3.4 & 3.6 & 2.8 & 4.1 & 0.8 \\
\hline HICP (end of period) & 4.0 & 2.7 & 3.3 & 3.7 & 2.7 & 4.3 & 1.5 & 1.5 \\
\hline Differential with euro area average & 1.3 & 1.0 & 0.9 & 1.2 & 1.4 & 0.7 & $\ldots$ & $\ldots$ \\
\hline \multicolumn{9}{|l|}{ Employment and wages } \\
\hline Unemployment rate (in percent) & 11.5 & 11.5 & 11.0 & 9.2 & 8.5 & 8.3 & 11.0 & 15.6 \\
\hline Unit labor cost in manufacturing & 2.7 & 2.7 & 1.6 & 2.5 & 2.7 & 1.1 & 6.3 & 1.0 \\
\hline Labor cost in manufacturing & 5.0 & 4.9 & 4.0 & 3.5 & 4.2 & 3.4 & 5.1 & 2.3 \\
\hline Employment growth & 2.4 & 3.1 & 3.5 & 4.1 & 3.9 & 3.0 & -0.4 & -3.9 \\
\hline Labor participation rate (in percent) 2/ & 70.3 & 71.2 & 72.0 & 72.1 & 73.2 & 73.9 & $\ldots$ & $\ldots$ \\
\hline \multicolumn{9}{|l|}{ Balance of payments (percent of GDP) } \\
\hline Trade balance (goods) & -5.0 & -5.1 & -6.4 & -7.5 & -8.5 & -8.5 & -8.2 & -4.4 \\
\hline Current account balance & -3.3 & -3.5 & -5.3 & -7.4 & -8.9 & -10.1 & -9.7 & -5.5 \\
\hline Official reserves excl. gold (US\$ billions) & 34.5 & 19.8 & 12.4 & 9.7 & 10.8 & 11.5 & $\ldots$ & $\ldots$ \\
\hline Nominal effective rate $(2000=100)$ & 102.9 & 106.7 & 107.8 & 105.9 & 107.4 & 109.8 & $\ldots$ & $\ldots$ \\
\hline Real effective rate $(2000=100, \mathrm{CPI}$-based $)$ & 106.5 & 111.2 & 113.4 & 113.3 & 115.8 & 119.7 & $\ldots$ & $\ldots$ \\
\hline \multicolumn{9}{|l|}{ Public finance (percent of GDP) } \\
\hline General government balance & -0.5 & -0.2 & -0.3 & 1.0 & 2.0 & 2.2 & -3.1 & -6.1 \\
\hline Primary balance & 2.2 & 2.1 & 1.7 & 2.8 & 3.7 & 3.8 & -1.5 & -4.4 \\
\hline Structural balance & -1.1 & -1.0 & -1.0 & -1.6 & -1.2 & -1.1 & -4.2 & -5.2 \\
\hline General government debt & 52.5 & 48.7 & 46.2 & 43.0 & 39.6 & 36.2 & 38.6 & 48.6 \\
\hline
\end{tabular}

Sources: IMF, World Economic Outlook; data provided by the authorites; and IMF staff estimates.

1/ Data for 2008 as of September.

2/ Based on national definition (i.e., the labor force is defined as people older than 16 and younger than 65). 
Table 2. Spain: Selected Financial Soundness Indicators (Percent or otherwise indicated)

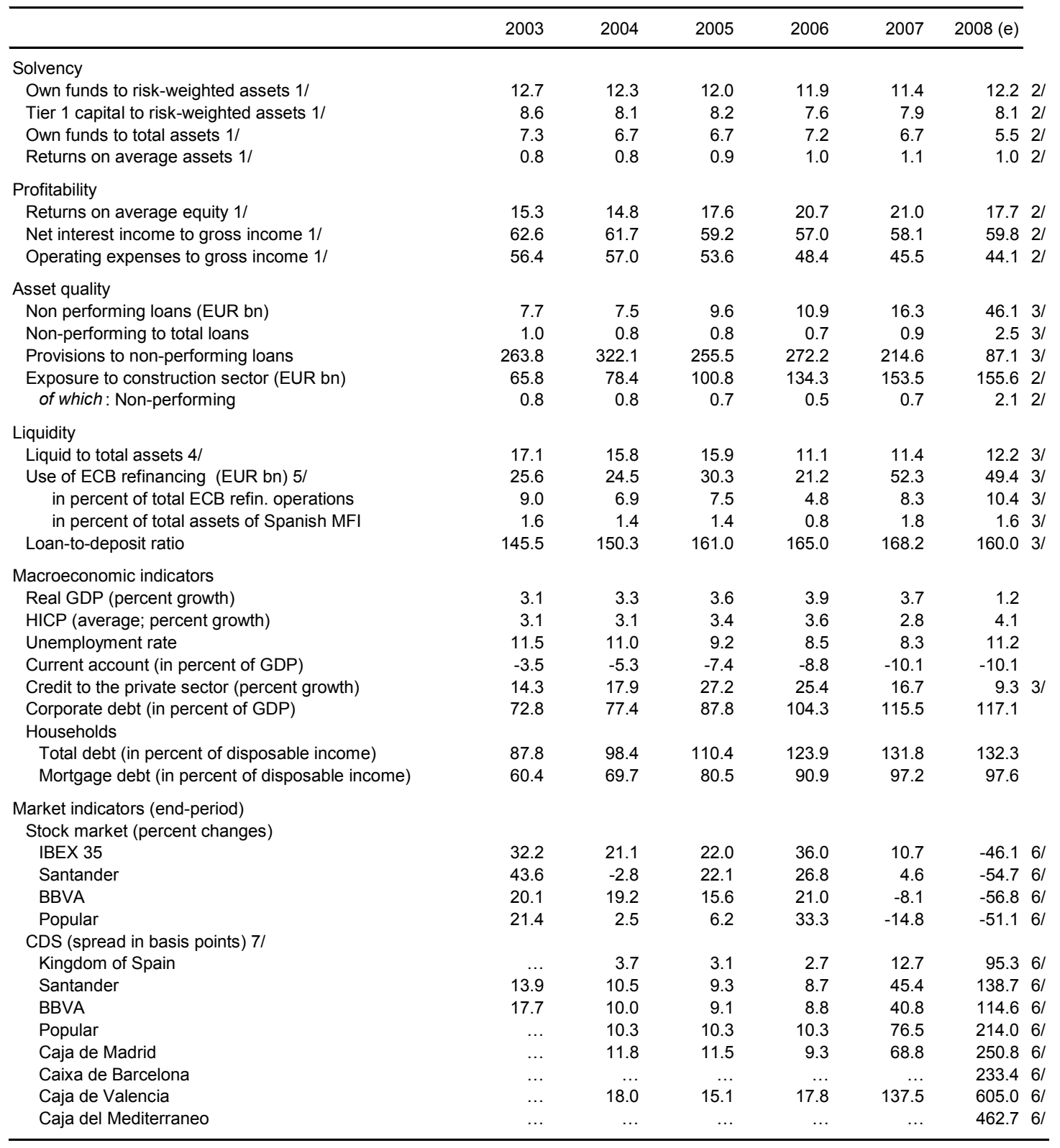

Sources: Bank of Spain; ECB; WEO; Bloomberg; and IMF staff estimates.

$1 /$ Consolidated groups of credit institutions.

2/ As of end-June.

$3 /$ As of end-August.

4/ Liquid assets include cash and holdings of securities different from equity shares and participations

5 / Sum of main and long-term refinancing operations; end of period.

6/ As of October 28, 2008.

$7 /$ Senior 5 years in euro. 
Table 3. Spain: Financial Soundness Indicators of the Non-banking Sectors

\begin{tabular}{|c|c|c|c|c|c|c|c|}
\hline & 2002 & 2003 & 2004 & 2005 & 2006 & 2007 & $20081 /$ \\
\hline \multicolumn{8}{|l|}{ Insurance sector } \\
\hline Solvency ratio $2 /$ & $\ldots$ & $\ldots$ & $\ldots$ & 2.8 & 2.7 & 2.6 & $\ldots$ \\
\hline Profitability (return on average equity) & 9.36 & 15.22 & 18.2 & 21.7 & 22.1 & 26.4 & $\ldots$ \\
\hline \multicolumn{8}{|l|}{ Corporate sector } \\
\hline Total debt as a percentage of GDP & 69.3 & 74.2 & 78.8 & 89.2 & 105.8 & 117.1 & 118.0 \\
\hline Total debt as a percentage of equity & 86.4 & 82.7 & 80.2 & 81.3 & 89.7 & 90.6 & $\ldots$ \\
\hline Profitability (Return on equity) & 11.0 & 11 & 11.9 & 12.8 & 13.2 & 12.5 & $\ldots$ \\
\hline Debt service (interest only) coverage $3 /$ & 6.0 & 6.8 & 7.3 & 6.4 & 4.6 & 3.2 & 2.9 \\
\hline \multicolumn{8}{|l|}{ Net foreign exchange exposure as a percentage of equity } \\
\hline Number of applications for protection from creditors & 1,021 & 996 & 915 & 929 & 906 & 976 & 1,562 \\
\hline \multicolumn{8}{|l|}{ Household sector } \\
\hline Debt as a precentage of GDP & 52.1 & 57.6 & 64.4 & 71.9 & 79.5 & 83.6 & 84.3 \\
\hline Debt as a precentage of disposable income & 79.3 & 88.3 & 98.9 & 110.4 & 123.1 & 131 & 131.3 \\
\hline Debt service burden to total disposable income & 12.4 & 12.5 & 13.3 & 14.2 & 15.6 & 17.5 & 17.9 \\
\hline Interest burden as a percentage of total disposable income & 4.1 & 4 & 4 & 4.1 & 4.9 & 6.5 & 7.1 \\
\hline Financial savings ratio as a percentage of GDP & 0.8 & 0.1 & -0.6 & -1.3 & -1.7 & -1.6 & -0.7 \\
\hline \multicolumn{8}{|l|}{ Real estate sector } \\
\hline House price inflation $4 /$ & 15.7 & 17.6 & 17.5 & 13.9 & 10.4 & 5.8 & 0.7 \\
\hline Mortgage loans as percent of total credit to the resident non-monetary private sector & 50.5 & 53.7 & 56.2 & 59.0 & 58.6 & 57.9 & 57.4 \\
\hline o/w Domestic households & 30.8 & 31.6 & 32.5 & 36.5 & 35.8 & 35.0 & 34.8 \\
\hline o/w real estate & 19.7 & 20.1 & 21.7 & 22.6 & 22.8 & 22.9 & 22.5 \\
\hline
\end{tabular}

Sources : Data received from the authorities and staff estimates.

$1 /$ As of end-June.

2/ Available solvency marging over required solvency margin.

$3 /$ Earnings before interest and tax as a percentage of interest and principal expenses.

4/ Assessed housing prices per square meter in the free housing market as published by the Ministry of Housing. 2008 data cover the entire year. 
Table 4. Spain: Status of Implementation of Main FSAP Recommendations

\begin{tabular}{|c|c|c|}
\hline & $\begin{array}{l}\text { Adoption timeframe } \\
\text { (since June 2006) }\end{array}$ & Status as reported by the authorities \\
\hline \multicolumn{3}{|l|}{ Macro Relevant Recommendations } \\
\hline $\begin{array}{l}\text { Tighten provisioning or capital requirements for } \\
\text { nontraditional housing and construction loans }\end{array}$ & Short term & $\begin{array}{l}\text { Circulars } 4 / 2004 \text { and } 3 / 2008 \text { provide a } \\
\text { prudent framework to address risks inherent } \\
\text { in nontraditional housing and construction } \\
\text { loans }\end{array}$ \\
\hline $\begin{array}{l}\text { Adopt most conservative approach under Basel II for } \\
\text { industrial participations }\end{array}$ & Short term & $\begin{array}{l}\text { Circular } 3 / 2008 \text { gives preference to VaR } \\
\text { approach although it is an option as indicated } \\
\text { in the EU Capital Requirement Directive and } \\
\text { Basel II framework }\end{array}$ \\
\hline \multicolumn{3}{|l|}{ Financial Sector Supervision } \\
\hline $\begin{array}{l}\text { Ongoing reforms of the Statutes of the Autonomous } \\
\text { Communities should clearly maintain prudential and } \\
\text { supervisory responsibilities at the State level }\end{array}$ & Short term & $\begin{array}{l}\text { Despite some ambiguities, Statute revisions } \\
\text { basically maintain status quo whereby Bank } \\
\text { of Spain retains full responsibility for } \\
\text { prudential and supervisory tasks }\end{array}$ \\
\hline $\begin{array}{l}\text { Separate insurance supervision from the Ministry of } \\
\text { Economy }\end{array}$ & Medium term & $\begin{array}{l}\text { A proposal to transfer solvency regulation to } \\
\text { the Bank of Spain and consumer protection } \\
\text { issues to the CNMV (twin peaks model) is } \\
\text { currently stalled }\end{array}$ \\
\hline $\begin{array}{l}\text { Delegate the authority to issue norms and sanction } \\
\text { violations from the Ministry of Economy and the Council } \\
\text { of Ministers to the respective regulatory agencies }\end{array}$ & $\begin{array}{l}\text { Short term or within } 12 \\
\text { months }\end{array}$ & Pending \\
\hline $\begin{array}{l}\text { Create an institutional mechanism for permanent and } \\
\text { continued coordination among the main regulators }\end{array}$ & Short term & $\begin{array}{l}\text { Establishment of the Financial Stability } \\
\text { Committee }\end{array}$ \\
\hline $\begin{array}{l}\text { Appoint members of the CNMV's board to longer non- } \\
\text { renewable terms }\end{array}$ & Medium term & Pending \\
\hline \multicolumn{3}{|l|}{ Issues Related to Savings Banks } \\
\hline $\begin{array}{l}\text { Monitor the results of the } 2002-03 \text { regulations on the } \\
\text { governance of savings banks, particularly as regards } \\
\text { outside influence on the decisions of savings banks, } \\
\text { strengthening them if required }\end{array}$ & $\begin{array}{l}\text { Medium term or } 1 \text { to } 3 \\
\text { years }\end{array}$ & Ongoing public debate \\
\hline $\begin{array}{l}\text { Allow savings banks to merge freely within and across } \\
\text { Autonomous Communities if the Bank of Spain approves }\end{array}$ & Medium term & $\begin{array}{l}\text { Legal framework unchanged but some } \\
\text { potential mergers underway, although mainly } \\
\text { within regions }\end{array}$ \\
\hline $\begin{array}{l}\text { Promote use of cuotas participativas to raise high-quality } \\
\text { capital and to introduce market discipline }\end{array}$ & Medium term & $\begin{array}{l}\text { One savings bank has issued cuotas } \\
\text { participativas }\end{array}$ \\
\hline $\begin{array}{l}\text { Reduce over time public sector representation ceiling on } \\
\text { savings bank boards }\end{array}$ & Medium term & Ongoing public debate \\
\hline
\end{tabular}

\section{CInternational Monetary Fund. Not for Redistribution}


Table 5. Spain: General Government Operations

\begin{tabular}{|c|c|c|c|c|c|c|c|c|}
\hline & \multicolumn{8}{|c|}{ Baseline scenario } \\
\hline & 2007 & 2008 & 2009 & 2010 & 2011 & 2012 & 2013 & 2014 \\
\hline & \multicolumn{8}{|c|}{ (Billions of euros) } \\
\hline Revenue & 431.1 & 405.7 & 397.4 & 402.8 & 417.0 & 434.1 & 455.1 & 480.8 \\
\hline Indirect taxes & 122.8 & 110.2 & 109.0 & 110.8 & 113.9 & 117.5 & 123.0 & 130.2 \\
\hline Personal (PIT) & 81.3 & 76.6 & 76.7 & 78.2 & 80.7 & 83.8 & 87.5 & 91.7 \\
\hline Corporate $(\mathrm{CIT})$ & 54.5 & 37.1 & 37.5 & 38.2 & 39.7 & 41.7 & 44.4 & 47.3 \\
\hline Social security contributions & 136.6 & 144.0 & 136.6 & 137.6 & 141.9 & 148.1 & 155.6 & 164.8 \\
\hline Other & 31.3 & 32.7 & 32.5 & 32.9 & 34.4 & 35.5 & 36.9 & 38.6 \\
\hline Capital & 4.6 & 5.0 & 5.0 & 5.1 & 6.3 & 7.5 & 7.8 & 8.1 \\
\hline Primary expenditure & 391.0 & 422.3 & 445.4 & 447.1 & 449.5 & 454.6 & 463.7 & 478.2 \\
\hline Wages and salaries & 107.1 & 116.7 & 120.2 & 122.9 & 125.5 & 128.1 & 130.8 & 134.7 \\
\hline Goods and services & 54.0 & 56.3 & 58.6 & 59.9 & 61.1 & 62.3 & 63.5 & 65.4 \\
\hline Social transfers & 148.3 & 160.9 & 170.0 & 173.8 & 177.2 & 178.8 & 182.5 & 187.1 \\
\hline Subsidies & 11.1 & 11.6 & 11.6 & 11.1 & 9.7 & 10.0 & 10.4 & 10.8 \\
\hline Other & 15.7 & 18.4 & 20.6 & 20.4 & 19.3 & 18.7 & 18.2 & 19.1 \\
\hline Capital & 54.9 & 58.4 & 64.4 & 59.0 & 56.9 & 56.7 & 58.3 & 61.2 \\
\hline Primary balance & 40.1 & -16.6 & -48.0 & -44.3 & -32.5 & -20.5 & -8.6 & 2.6 \\
\hline Interest & 16.9 & 17.2 & 18.6 & 21.6 & 24.0 & 26.3 & 28.2 & 29.7 \\
\hline \multirow[t]{2}{*}{ Overall balance } & 23.3 & -33.8 & -66.6 & -65.8 & -56.5 & -46.8 & -36.8 & -27.1 \\
\hline & \multicolumn{8}{|c|}{ (Percent of GDP) } \\
\hline Revenue & 41.0 & 37.0 & 36.4 & 36.5 & 36.8 & 37.2 & 37.5 & 37.9 \\
\hline Direct taxes & 12.9 & 10.4 & 10.5 & 10.5 & 10.6 & 10.7 & 10.9 & 11.0 \\
\hline Personal (PIT) & 7.7 & 7.0 & 7.0 & 7.1 & 7.1 & 7.2 & 7.2 & 7.2 \\
\hline Corporate $(\mathrm{CIT})$ & 5.2 & 3.4 & 3.4 & 3.5 & 3.5 & 3.6 & 3.7 & 3.7 \\
\hline Social security contributions & 13.0 & 13.1 & 12.5 & 12.5 & 12.5 & 12.7 & 12.8 & 13.0 \\
\hline Other & 3.0 & 3.0 & 3.0 & 3.0 & 3.0 & 3.0 & 3.0 & 3.0 \\
\hline Capital & 0.4 & 0.5 & 0.5 & 0.5 & 0.6 & 0.6 & 0.6 & 0.6 \\
\hline Primary expenditure & 37.2 & 38.5 & 40.8 & 40.5 & 39.7 & 38.9 & 38.3 & 37.7 \\
\hline Wages and salaries & 10.2 & 10.7 & 11.0 & 11.1 & 11.1 & 11.0 & 10.8 & 10.6 \\
\hline Goods and services & 5.1 & 5.1 & 5.4 & 5.4 & 5.4 & 5.3 & 5.2 & 5.2 \\
\hline Social transfers & 14.1 & 14.7 & 15.6 & 15.7 & 15.7 & 15.3 & 15.1 & 14.8 \\
\hline Subsidies & 1.1 & 1.1 & 1.1 & 1.0 & 0.9 & 0.9 & 0.9 & 0.9 \\
\hline Other & 1.5 & 1.7 & 1.9 & 1.8 & 1.7 & 1.6 & 1.5 & 1.5 \\
\hline Capital & 5.2 & 5.3 & 5.9 & 5.3 & 5.0 & 4.9 & 4.8 & 4.8 \\
\hline Primary balance & 3.8 & -1.5 & -4.4 & -4.0 & -2.9 & -1.8 & -0.7 & 0.2 \\
\hline Interest & 1.6 & 1.6 & 1.7 & 2.0 & 2.1 & 2.3 & 2.3 & 2.3 \\
\hline Overall balance & 2.2 & -3.1 & -6.1 & -6.0 & -5.0 & -4.0 & -3.0 & -2.1 \\
\hline Government debt $1 /$ & 36.2 & 38.6 & 48.6 & 53.8 & 56.8 & 55.6 & 56.6 & 56.3 \\
\hline Government debt and guaranteed debt 2/ & 38.9 & 52.0 & 74.5 & 80.4 & 74.0 & 63.7 & 64.4 & 63.7 \\
\hline Memorandum items: & & & & & & & & \\
\hline Structural balance & -1.1 & -4.2 & -5.2 & -4.3 & -3.3 & -2.5 & -1.8 & -1.3 \\
\hline
\end{tabular}

Sources: Cuentas Financieras and Boletin Estadistico, Bank of Spain; and IMF staff projections.

1/ Includes the FAAF.

2/Includes government guarantees and ICO credit lines assuming their full use. 
Table 6. Spain: Public Sector Balance Sheet (Preliminary)

\begin{tabular}{|c|c|c|c|c|c|c|}
\hline & 2000 & 2005 & 2006 & 2007 & 2008 & 2009 \\
\hline & \multicolumn{6}{|c|}{ (Billions of euros) } \\
\hline Financial assets & 169 & 241 & 274 & 302 & 325 & 364 \\
\hline Currency and deposits & 57 & 76 & 89 & 101 & 105 & 105 \\
\hline Securities other than shares & 2 & 31 & 40 & 50 & 52 & 51 \\
\hline Loans & 26 & 35 & 37 & 41 & 43 & 43 \\
\hline Shares and other equity & 59 & 71 & 77 & 82 & 85 & 85 \\
\hline Other accounts receivable & 26 & 29 & 30 & 29 & 30 & 30 \\
\hline Assets of FAAF & 0 & 0 & 0 & 0 & 10 & 50 \\
\hline Financial liabilities & 448 & 517 & 514 & 505 & 557 & 663 \\
\hline Currency and deposits & 3 & 3 & 3 & 3 & 3 & 3 \\
\hline Securities other than shares & 335 & 382 & 364 & 350 & 395 & 502 \\
\hline Loans & 73 & 82 & 82 & 81 & 84 & 84 \\
\hline Other accounts payable & 36 & 50 & 65 & 72 & 75 & 74 \\
\hline Financial Net worth & -279 & -276 & -240 & -203 & -233 & -299 \\
\hline Nonfinancial fixed assets (net) & 303 & 436 & 472 & 504 & 526 & 524 \\
\hline Current net worth & 24 & 161 & 232 & 301 & 293 & 224 \\
\hline NPV of future primary balances $1 /$ & -73 & -392 & -478 & -717 & $-1,736$ & $-1,826$ \\
\hline Intertemporal net worth & -49 & -231 & -246 & -416 & $-1,443$ & $-1,602$ \\
\hline \multirow[t]{2}{*}{ Intertemporal financial net worth $2 /$} & -352 & -668 & -718 & -920 & $-1,969$ & $-2,125$ \\
\hline & \multicolumn{6}{|c|}{ (Percent of GDP) } \\
\hline Financial net worth & -44 & -30 & -24 & -19 & -21 & -27 \\
\hline Current net worth & 4 & 18 & 24 & 29 & 27 & 21 \\
\hline NPV of future primary balances & -12 & -43 & -49 & -68 & -158 & -167 \\
\hline Intertemporal net worth & -8 & -25 & -25 & -40 & -132 & -147 \\
\hline Intertemporal financial net worth & -56 & -73 & -73 & -88 & -180 & -195 \\
\hline \multicolumn{7}{|l|}{ Memorandum items: } \\
\hline Government debt 3/ & 59 & 43 & 40 & 36 & 39 & 49 \\
\hline Government debt and guaranteed debt 4/ & 62 & 45 & 42 & 39 & 52 & 74 \\
\hline GDP & 630 & 909 & 982 & 1,051 & 1,096 & 1,091 \\
\hline
\end{tabular}

Sources: Bank of Spain; and IMF staff estimates.

$1 /$ Net present value of 50-year future primary balance projections in the baseline scenario of unchanged policies. The discount rate is equal to the average interest rate on the public debt. Over the long-run the real interest rate $=$ real GDP growth $+100 \mathrm{bp}$.

2/ Excludes fixed assets as these may not be marketable.

3/ Includes the FAAF.

4/ Includes government guarantees and ICO credit lines assuming their full use. 
Table 7. Spain: Balance of Payments

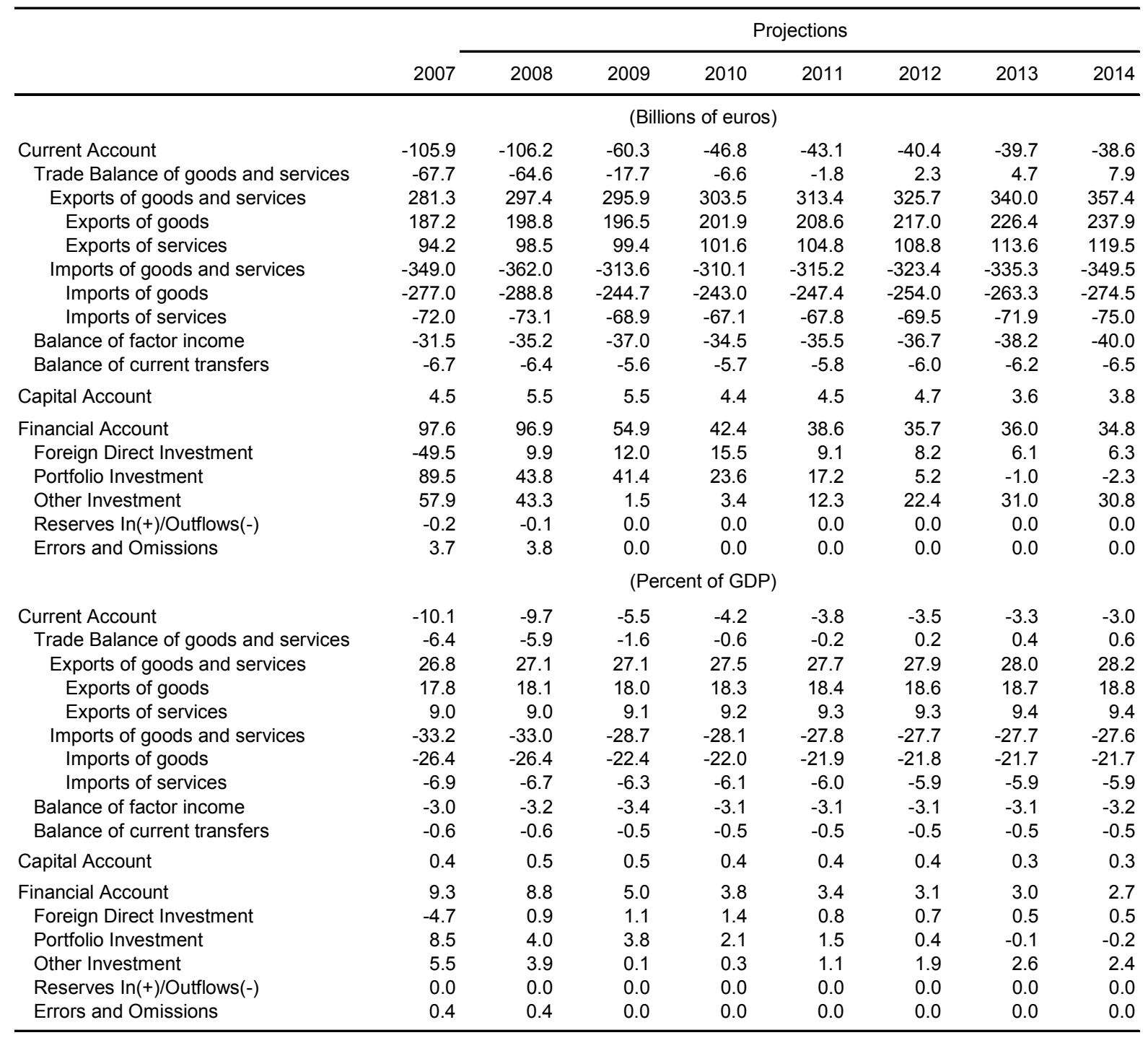

Sources: Bank of Spain; and IMF staff projections. 
Table 8. Spain: International Investment Position

\begin{tabular}{|c|c|c|c|c|c|c|}
\hline & 2003 & 2004 & 2005 & 2006 & 2007 & $20081 /$ \\
\hline & \multicolumn{6}{|c|}{ (Billions of euros) } \\
\hline International Investment Position & -298 & -436 & -505 & -668 & -826 & -867 \\
\hline Direct Investment & -37 & -92 & -67 & -41 & -12 & -17 \\
\hline Assets & 232 & 207 & 259 & 310 & 395 & 429 \\
\hline Liabilities & 269 & 299 & 326 & 351 & 407 & 445 \\
\hline Portfolio Investment & -102 & -203 & -274 & -509 & -648 & -630 \\
\hline Assets & 320 & 359 & 455 & 456 & 443 & 389 \\
\hline Liabilities & 422 & 562 & 728 & 965 & 1,091 & 1,019 \\
\hline Financial Derivatives & 0 & 0 & 0 & -10 & -19 & -12 \\
\hline Other Investment & -214 & -209 & -237 & -203 & -226 & -266 \\
\hline Assets & 204 & 222 & 268 & 327 & 383 & 427 \\
\hline Liabilities & 418 & 432 & 505 & 531 & 609 & 693 \\
\hline Bank of Spain & 56 & 68 & 72 & 96 & 79 & 57 \\
\hline \multirow[t]{2}{*}{ o/w Reserve Assets } & 21 & 15 & 15 & 15 & 13 & 14 \\
\hline & \multicolumn{6}{|c|}{ (Percent of GDP) } \\
\hline International Investment Position & -38.0 & -51.9 & -55.6 & -68.0 & -78.6 & -79.5 \\
\hline Direct Investment & -4.8 & -10.9 & -7.4 & -4.2 & -1.2 & -1.5 \\
\hline Assets & 29.6 & 24.6 & 28.5 & 31.5 & 37.6 & 39.3 \\
\hline Liabilities & 34.3 & 35.6 & 35.9 & 35.7 & 38.8 & 40.8 \\
\hline Portfolio Investment & -13.1 & -24.2 & -30.1 & -51.8 & -61.6 & -57.8 \\
\hline Assets & 40.8 & 42.7 & 50.0 & 46.4 & 42.2 & 35.7 \\
\hline Liabilities & 53.9 & 66.9 & 80.1 & 98.2 & 103.8 & 93.4 \\
\hline Financial Derivatives & 0.0 & 0.0 & 0.0 & -1.0 & -1.8 & -1.1 \\
\hline Other Investment & -27.4 & -24.9 & -26.0 & -20.7 & -21.5 & -24.4 \\
\hline Assets & 26.1 & 26.4 & 29.5 & 33.3 & 36.5 & 39.1 \\
\hline Liabilities & 53.4 & 51.3 & 55.5 & 54.0 & 58.0 & 63.5 \\
\hline Bank of Spain & 7.2 & 8.1 & 7.9 & 9.7 & 7.5 & 5.2 \\
\hline o/w Reserve Assets & 2.7 & 1.7 & 1.6 & 1.5 & 1.2 & 1.3 \\
\hline
\end{tabular}

Source: Bank of Spain.

1/ Data for end of 2008Q3. The nominal GDP figure refers to the four quarters to 2008Q3. 
Table 9.Spain: External Debt Sustainability Framework

(Percent of GDP, unless otherwise indicated)

\begin{tabular}{|c|c|c|c|c|c|c|c|c|c|c|c|c|}
\hline & \multicolumn{5}{|c|}{ Actual } & \multicolumn{6}{|c|}{ Projections } & \multirow{3}{*}{$\begin{array}{c}\text { Debt-stabilizing } \\
\text { non-interest } \\
\text { current account } 6 / \\
1.0\end{array}$} \\
\hline & 2003 & 2004 & 2005 & 2006 & 2007 & 2008 & 2009 & 2010 & 2011 & 2012 & 2013 & \\
\hline Baseline: External debt & 88.4 & 96.4 & 114.0 & 127.2 & 134.5 & 138.6 & 144.6 & 149.0 & 153.3 & 156.6 & 159.4 & \\
\hline Change in external debt & 4.5 & 8.0 & 17.6 & 13.2 & 7.3 & 4.1 & 6.0 & 4.4 & 4.3 & 3.3 & 2.8 & \\
\hline Identified external debt-creating flows $(4+8+9)$ & -0.7 & 2.1 & 2.5 & 8.3 & 6.1 & 7.2 & 6.5 & 2.4 & 0.9 & -0.2 & -0.7 & \\
\hline Current account deficit, excluding interest payments & -0.8 & 0.7 & 2.1 & 2.5 & 2.2 & 1.3 & -2.9 & -4.0 & -4.4 & -4.7 & -4.9 & \\
\hline Deficit in balance of goods and services & 2.1 & 3.8 & 5.1 & 6.2 & 6.4 & 5.9 & 1.6 & 0.6 & 0.2 & -0.2 & -0.4 & \\
\hline Exports & 26.2 & 26.0 & 25.8 & 26.5 & 26.8 & 27.1 & 27.1 & 27.5 & 27.7 & 27.9 & 28.0 & \\
\hline Imports & 28.4 & 29.8 & 30.9 & 32.7 & 33.2 & 33.0 & 28.7 & 28.1 & 27.8 & 27.7 & 27.7 & \\
\hline Net non-debt creating capital inflows (negative) & 0.7 & 2.5 & 2.4 & 7.8 & 3.6 & -1.1 & -1.5 & -2.0 & -1.6 & -1.6 & -1.5 & \\
\hline Automatic debt dynamics $1 /$ & -0.6 & -1.1 & -1.9 & -2.0 & 0.3 & 7.0 & 10.9 & 8.3 & 6.8 & 6.1 & 5.7 & \\
\hline Contribution from nominal interest rate & 4.3 & 4.6 & 5.3 & 6.5 & 7.9 & 8.4 & 8.4 & 8.2 & 8.2 & 8.2 & 8.2 & \\
\hline Contribution from real GDP growth & -2.0 & -2.4 & -3.2 & -4.1 & -4.0 & -1.4 & 2.4 & 0.1 & -1.3 & -2.0 & -2.5 & \\
\hline Contribution from price and exchange rate changes $2 /$ & -2.9 & -3.2 & -4.0 & -4.4 & -3.6 & $\ldots$ & $\ldots$ & $\ldots$ & $\ldots$ & $\ldots$ & $\ldots$ & \\
\hline Residual, incl. change in gross foreign assets $(2-3) 3 /$ & 5.2 & 5.9 & 15.0 & 5.0 & 1.2 & -3.1 & -0.5 & 2.0 & 3.5 & 3.5 & 3.5 & \\
\hline External debt-to-exports ratio (in percent) & 337.0 & 371.4 & 442.2 & 479.5 & 502.3 & 511.0 & 533.4 & 542.3 & 553.8 & 561.3 & 568.3 & \\
\hline $\begin{array}{l}\text { Gross external financing need (in billions of US dollars) } 4 / \\
\text { percent of GDP }\end{array}$ & $\begin{array}{r}317.7 \\
35.9\end{array}$ & $\begin{array}{r}453.8 \\
43.4\end{array}$ & $\begin{array}{r}561.3 \\
49.6\end{array}$ & $\begin{array}{r}744.9 \\
60.4\end{array}$ & $\begin{array}{r}857.8 \\
59.6\end{array}$ & $\begin{array}{r}1061.7 \\
63.6\end{array}$ & $\begin{array}{r}1285.3 \\
78.4\end{array}$ & $\begin{array}{r}1294.0 \\
77.6\end{array}$ & $\begin{array}{r}1347.0 \\
78.5\end{array}$ & $\begin{array}{r}1418.3 \\
79.8\end{array}$ & $\begin{array}{r}1496.0 \\
80.8\end{array}$ & \\
\hline Scenario with key variables at their historical averages 5/ & & & & & & 138.6 & 135.7 & 137.2 & 139.8 & 142.3 & 145.1 & -1.9 \\
\hline \multicolumn{13}{|l|}{ Key Macroeconomic Assumptions Underlying Baseline } \\
\hline Real GDP growth (in percent) & 3.1 & 3.3 & 3.6 & 3.9 & 3.7 & 1.2 & -1.7 & -0.1 & 0.9 & 1.4 & 1.6 & \\
\hline GDP deflator in US dollars (change in percent) & 24.7 & 14.4 & 4.5 & 4.9 & 12.6 & 14.6 & -0.1 & 1.8 & 1.9 & 2.2 & 2.6 & \\
\hline Nominal external interest rate (in percent) & 6.6 & 6.1 & 5.9 & 6.2 & 7.2 & 7.2 & 6.0 & 5.8 & 5.7 & 5.5 & 5.5 & \\
\hline Growth of exports (US dollar terms, in percent) & 24.0 & 16.8 & 7.5 & 12.2 & 17.8 & 17.5 & -1.9 & 3.0 & 3.7 & 4.4 & 4.8 & \\
\hline Growth of imports (US dollar terms, in percent) & 25.2 & 23.9 & 12.4 & 15.5 & 18.5 & 15.3 & -14.6 & -0.7 & 2.1 & 3.0 & 4.1 & \\
\hline Current account balance, excluding interest payments & 0.8 & -0.7 & -2.1 & -2.5 & -2.2 & -1.3 & 2.9 & 4.0 & 4.4 & 4.7 & 4.9 & \\
\hline Net non-debt creating capital inflows & -0.7 & -2.5 & -2.4 & -7.8 & -3.6 & 1.1 & 1.5 & 2.0 & 1.6 & 1.6 & 1.5 & \\
\hline
\end{tabular}

Source: IMF staff calculations. Some data in this table may not correspond exactly to those published by the Bank of Spain because of small variations in definitions.

1/ Derived as $[r-g-\rho(1+g)+\varepsilon \alpha(1+r)] /(1+g+\rho+g \rho)$ times previous period debt stock, with $r=$ nominal effective interest rate on external debt; $\rho=$ change in domestic GDP deflator in US dollar terms, $g=$ real GDP growth rate, $\varepsilon=$ nominal appreciation (increase in dollar value of domestic currency), and $\alpha=$ share of domestic-currency denominated debt in total external debt. Data on debt service and amortization used in the calculations are estimated.

2/ The contribution from price and exchange rate changes is defined as $[-\rho(1+g)+\varepsilon \alpha(1+r)] /(1+g+\rho+g \rho)$ times previous period debt stock. $\rho$ increases with an appreciating domestic currency $(\varepsilon>0)$ and rising inflation (based on GDP deflator).

3 / For projection, line includes the impact of price and nominal exchange rate changes (REER is unchanged).

4/ Defined as current account deficit, plus amortization on medium- and long-term debt, plus short-term debt at end of previous period.

5/ The key variables include real GDP growth; nominal interest rate; dollar deflator growth; and both non-interest current account and non-debt inflows in percent of GDP.

6/ Long-run, constant balance that stabilizes the debt ratio assuming that key variables (real GDP growth, nominal interest rate, dollar deflator growth, and non-debt inflows in percent of GDP) remain at their levels of the last projection year. 


\section{Spain: External Debt Sustainability: Bound Tests 1/}

(External debt in percent of GDP)
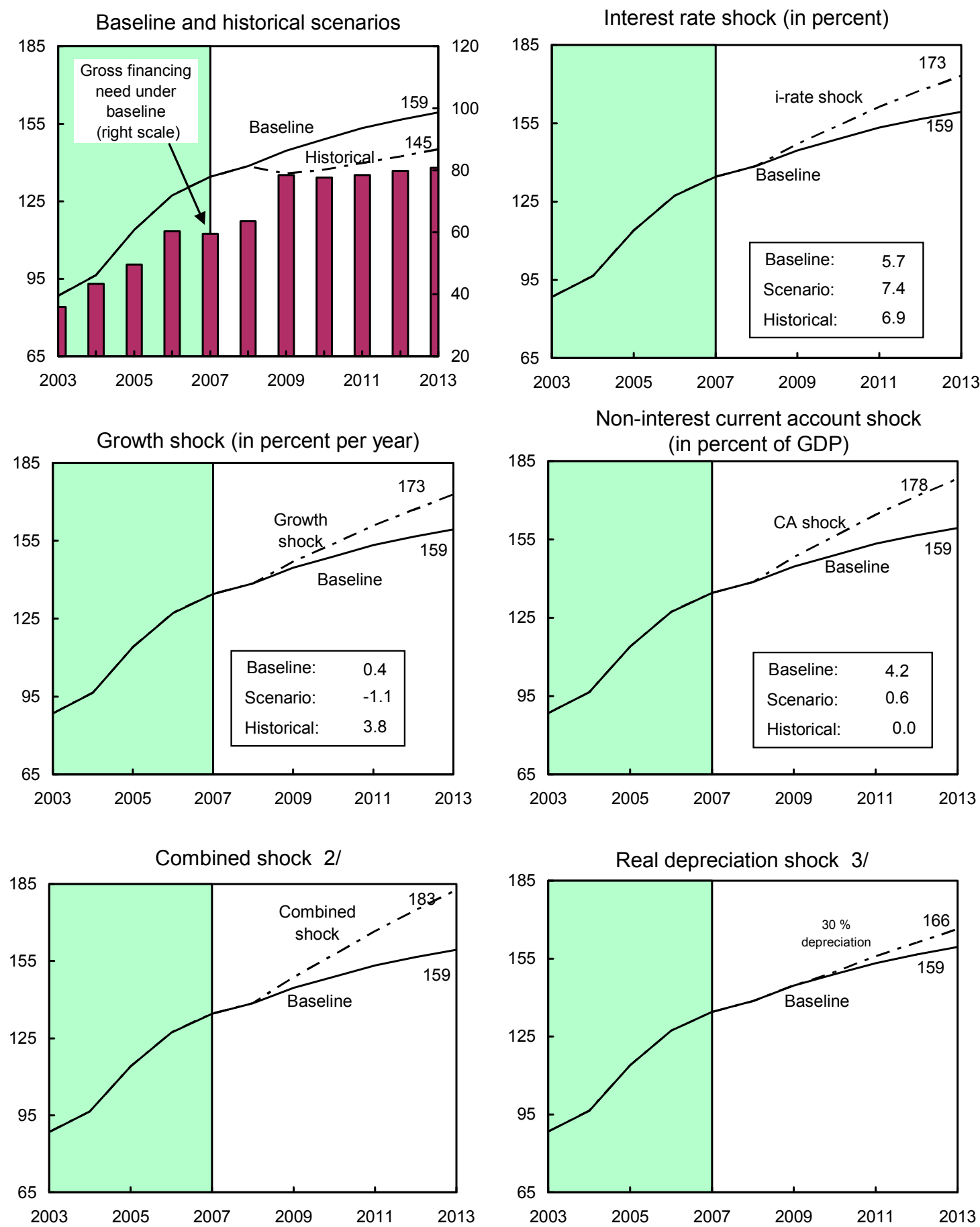

Sources: International Monetary Fund, Country desk data, and staff estimates.

1/ Data on debt service and amortization used in the calculations are estimated. Shaded areas represent actual data. Individual shocks are permanent two standard deviation shocks. Figures in the boxes represent average projections for the respective variables in the baseline and scenario being presented. Ten-year historical average for the variable is also shown.

2/ Permanent one standard deviation shocks applied to real interest rate, growth rate, and current account balance.

3/ One-time real depreciation of 30 percent occurs in 2009. 


\section{INTERNATIONAL MONETARY \\ SPAIN}

\section{Staff Report for the 2008 Article IV Consultation-Informational Annex}

Prepared by the European Department

February 3, 2009

Contents

Page

Appendix

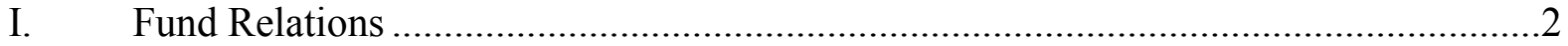




\section{Appendix I. Spain: Fund Relations}

(As of December 31, 2008)

I. Membership Status: Joined September 15, 1958.

II. General Resources Account:

Quota

Fund holdings of currency

Reserve position in Fund

$\begin{array}{cc}\text { SDR Million } & \text { Percent of Quota } \\ 3,048.90 & 100.00 \\ 2,626.61 & 86.15 \\ 422.32 & 13.85\end{array}$

III. SDR Department:

Net cumulative allocation

SDR Million Percent of Allocation

Holdings

$298.81 \quad 100.00$

$144.92 \quad 48.50$

IV. Projected Payments to Fund (SDR Million):

\begin{tabular}{cccccc}
\hline \multicolumn{7}{c}{ Forthcoming } \\
\hline & 2009 & 2010 & 2011 & 2012 & 2013 \\
\hline Charges/Interest & 1.37 & 1.28 & 1.28 & 1.28 & 1.28 \\
\hline Total & 1.37 & 1.28 & 1.28 & 1.28 & 1.28 \\
\hline
\end{tabular}

V. 2008 Article IV Consultation: A staff team comprising B. Traa (Head), K. Honjo, M. Moreno-Badia, C. Henn (all EUR), and A. Giustiniani (MCM) visited Madrid on November 28-December 9, 2008 to conduct the 2008 Article IV Consultation discussions. Mr. Guzman and Ms. Valle, from the Spanish Executive Director's office, joined the discussions. For outreach, the mission met with parliamentarians, trade unions, employers' organizations, bankers, and independent analysts. The concluding statement was published and the staff report is expected to be published as well. The Consultation includes background papers on (1) Developments in the Spanish Housing Sector; (2) The Spanish Banking System; (3) Long-Run Fiscal Outlook and the Public Sector Balance Sheet; and (4) Productivity Growth and Structural Reforms. The Consultation is also informed by the country report No. 08/145: France, Greece, Italy, Portugal, and Spain, Competitiveness in the Southern Euro Area. Spain is on a standard 12-month cycle. The last Article IV consultation discussions were concluded on May 16, 2007 (EBM/07/42-1).

VI. Exchange Rate Arrangements and Restrictions: Spain's currency is the euro, which floats freely and independently against other currencies. Spain has accepted the obligations of Article VIII, Sections 2, 3, and 4, and maintains an exchange rate system free of restrictions on payments and transfers for current international transactions, other than restrictions notified to the Fund under Decision No. 144 $(52 / 51)$. 
INTERNATIONAL MONETARY FUND

\author{
Spain \\ Staff Report for the 2008 Article IV Consultation with Spain \\ Supplementary Information \\ Prepared by the European Department \\ Approved by Ajai Chopra and Martin Mühleisen
}

March 6, 2009

The following information has become available since the preparation of the staff report. This information does not alter the thrust of the staff appraisal.

- $\quad$ Projections for real GDP growth are being revised down. In the last quarter of 2008, growth was -1.0 percent $(\mathrm{Q} / \mathrm{Q})$ compared with -0.7 percent projected in the staff report. With weak activity continuing in the first quarter, the staff now projects that growth in 2009 could be as low as -3.0 percent, compared with -1.7 percent in the staff report. Moderate quarterly growth is expected to resume in the first half of 2010.

- $\quad$ CPI inflation is declining faster than expected. Inflation was 0.7 percent $(\mathrm{Y} / \mathrm{Y})$ in February, reflecting the demand downturn and lower energy prices. It is now slightly below euro-partner countries, and expected to remain very low in 2009 on average.

- Unemployment is increasing faster than expected. In the last quarter of 2008 , the unemployment rate jumped to 13.9 percent. The staff believes that unemployment could peak at over 19 percent of the workforce in 2010.

- Imbalances are declining. The private sector is strongly cutting debt (the stock of mortgage credit is declining in nominal terms). Lower euribor interest rates and energy prices are providing a boost to households, but the momentum of declining activity with increasing unemployment is holding back spending. Toward end-2008, imports started falling at a double digit rate. Exports are falling slightly less and the external current account deficit is shrinking substantially.

- $\quad$ Fiscal results. The authorities increased their estimate for the 2008 general government deficit to 3.8 percent of GDP. With this shift, and considering the downward revision in growth, the staff is now projecting a 2009 fiscal deficit of $7 \frac{1}{2}$ percent of GDP. Spain has lost its AAA credit rating and the sovereign spread over 10-year German bonds has risen from 80 to around $115 \mathrm{bp}$.

- The banking system made substantial profits in 2008, but these began to decline toward year-end. With the recession accelerating, higher unemployment, and a continued drop in home values, impaired loans have risen to $3 \frac{1}{2}$ percent for the banking system as a whole. 
Loan-loss-provision coverage has declined to 70 percent (from above 200 percent as of end2007). Funding conditions remain tight, and banks have placed some 20 billion euros in high-grade securities with the government's liquidity assistance fund (FAAF). Some banks have made use of government guarantees to place debt.

- Bank consolidation. As foreshadowed in the staff report, pressure on the banking system is increasing. In particular, savings banks (cajas) are contemplating mergers, even among cajas in different regions, which would be unprecedented. The Spanish authorities have stated their preference for market-based solutions of weaker institutions, but they also are ready to assist banks with capital injections if this were to become necessary.

- $\quad$ Structural reforms. The OECD is updating its product and service market reform indicators. In the latest findings, Spain has made good progress, advancing in the rankings among countries. However, labor market reforms are stuck, and the employers and unions are making limited progress in the "Social Dialogue." The government continues to be concerned that modifications in severance pay arrangements and other market flexibilizing reforms would be akin to undermining worker's rights. Nevertheless, as indicated in the report, staff sees the rigid labor structures as one reason for Spain's competitiveness difficulties and high rate of unemployment, accentuated at this time by the weakness in aggregate demand.

Spain: Key Economic Indicators - Update from the Staff Report

\begin{tabular}{|c|c|c|c|c|c|c|}
\hline & \multirow{2}{*}{$\begin{array}{r}\text { Prel. /Est. } \\
2008 \\
\end{array}$} & \multicolumn{2}{|c|}{ Projections } & \multirow{2}{*}{$\begin{array}{r}\text { Prel. /Est. } \\
2008 \\
\end{array}$} & \multicolumn{2}{|c|}{ Projections } \\
\hline & & 2009 & 2010 & & 2009 & 2010 \\
\hline & \multicolumn{3}{|c|}{ Staff Report } & \multicolumn{3}{|c|}{ Update } \\
\hline & \multicolumn{6}{|c|}{ (Percent change otherwise indicated) } \\
\hline Real GDP growth & 1.2 & -1.7 & -0.1 & 1.2 & -3.0 & -0.7 \\
\hline Total domestic demand & 0.5 & -5.0 & -1.4 & 0.2 & -6.3 & -1.7 \\
\hline Consumption & 1.6 & -0.7 & 0.0 & 1.4 & -1.2 & 0.1 \\
\hline Fixed investment & -2.1 & -15.7 & -6.1 & -3.0 & -19.1 & -7.3 \\
\hline Net exports (contribution to growth) & 0.7 & 3.6 & 1.4 & 1.0 & 3.7 & 1.0 \\
\hline CPI inflation, pa & 4.1 & 0.8 & 1.6 & 4.1 & 0.5 & 1.5 \\
\hline \multirow[t]{2}{*}{ Unemployment Rate (percent) } & 11.0 & 15.6 & 17.0 & 11.3 & 17.7 & 19.3 \\
\hline & \multicolumn{6}{|c|}{ (Percent of GDP) } \\
\hline Current account balance & -9.7 & -5.5 & -4.2 & -9.6 & -5.4 & -4.4 \\
\hline General government balance & -3.1 & -6.1 & -6.0 & -3.8 & -7.5 & -7.5 \\
\hline Structural balance & -4.2 & -5.2 & -4.3 & -4.2 & -5.2 & -4.3 \\
\hline General government debt & 38.6 & 48.6 & 53.8 & 39.4 & 51.5 & 58.5 \\
\hline
\end{tabular}




\section{INTERNATIONAL MONETARY FUND}

EXTERNAL

RELATIONS

Public Information Notice

DEPARTMENT

Public Information Notice (PIN) No. 09/50

FOR IMMEDIATE RELEASE

April 22, 2009
International Monetary Fund

$70019^{\text {th }}$ Street, NW

Washington, D. C. 20431 USA

\section{IMF Executive Board Concludes 2008 Article IV Consultation with Spain}

On March 11, 2009, the Executive Board of the International Monetary Fund (IMF) concluded the Article IV consultation with Spain. ${ }^{1}$

\section{Background}

After 15 years of impressive growth led by a housing boom, the Spanish economy has entered a sharp downturn in the wake of the global liquidity squeeze since mid-2007. With reduced funding for the large external deficit and housing boom, what started as a soft landing turned into an abrupt unwinding of imbalances. Private consumption slowed markedly reflecting weakening disposable incomes, uncertainty associated with rising unemployment, and efforts to reduce private debt (deleveraging). Housing investment has slumped as have outlays on machinery and equipment. In turn, the external current account deficit has started to narrow from a deficit of 10 percent of GDP in 2007, with a lower oil import bill and domestic demand. The general government balance has switched from moderate surpluses in 2005-07 to sizeable deficits, reflecting discretionary measures to assist the economy during the downturn and a drop in important tax bases, including housing. The debt ratio is increasing quickly from a recent low of 36.2 percent of GDP.

Banks are under strain and impaired loans are increasing, reflecting the housing market downturn and growing unemployment. Wholesale funding remains tight and competition to attract deposits is intense. While banks have weathered well the first impact of the global crisis

\footnotetext{
${ }^{1}$ Under Article IV of the IMF's Articles of Agreement, the IMF holds bilateral discussions with members, usually every year. A staff team visits the country, collects economic and financial information, and discusses with officials the country's economic developments and policies. On return to headquarters, the staff prepares a report, which forms the basis for discussion by the Executive Board. At the conclusion of the discussion, the Managing Director, as Chairman of the Board, summarizes the views of Executive Directors, and this summary is transmitted to the country's authorities.
}

Washington, D.C. 20431 • Telephone 202-623-7100 • Fax 202-623-6772 • www.imf.org 
thanks to prudent regulation, sound supervision, and cautious retail-oriented business models, their operating environment is becoming very difficult with the extended deep downturn. The authorities have put in place a valuable package of assistance measures for banks. This includes extending deposit insurance and providing direct funding (Fondo para la Adquisición de Activos Financieros) and funding guarantees.

Despite the economic slowdown, wage and unit-labor costs are outpacing those in europartner countries and inflation remains structurally above the euro average. This reflects several factors including insufficiently contested domestic output markets, segmented labor markets, and relatively low productivity and competitiveness.

\section{Executive Board Assessment}

Executive Directors noted that, following a long period of strong growth, the Spanish economy has entered a severe downturn. While a gradual correction of the imbalances built up during the boom years had already been under way, the global financial crisis has triggered their abrupt unwinding. Directors expected the downturn in 2009 to be substantial, driven by deleveraging in the private sector and weak external conditions.

Directors commended the authorities for their timely and substantial fiscal and financial sector responses to help cushion the downturn. They emphasized that these efforts need to be complemented by reforms to bolster competitiveness and to avoid a prolonged period of slow growth and high unemployment which would make returning to fiscal sustainability more difficult. They underscored the need for sustained efforts to reduce domestic costs and increase flexibility and productivity, aimed at slowing the growth of unit labor costs.

Directors concurred that adjustment in the housing sector would likely take time. They welcomed the authorities' efforts to activate the rental market to lower vacancies, and to provide mortgage assistance to newly unemployed workers in order to limit foreclosures. Most Directors questioned the desirability of building more subsidized homes given that they could add to inventory at this time.

Directors commended Spain's early application of bold countercyclical fiscal policies, and encouraged the authorities to build on these policies to achieve growth-enhancing reforms. They felt that automatic stabilizers should continue to function freely. Given the projected increase in the public debt ratio and the possible need for assistance to banks, further fiscal stimulus measures should be considered only if warranted by a further worsening of the downturn. These measures should be well-targeted and aim at facilitating structural reforms. More generally, Directors underscored the need for fiscal policies to be anchored in a prudent, long-term sustainability framework. They encouraged the authorities to publish an intertemporal public sector balance sheet as part of the annual budget documents, showing the debt already incurred and the consequences of present policies on future deficits. Given the 
high costs associated with an aging population, Directors stressed the need for pension and other long-term reforms to ensure fiscal sustainability.

Directors stressed the need for a vigorous implementation of product and labor market reforms to improve competitiveness, reduce the inflation differential with the euro area, and increase productivity. They welcomed the plans for product and service market reforms that are in line with a unified EU market for goods and services, and looked forward to the timely implementation of the relevant Directives. Directors generally called for comprehensive labor market reforms. In this regard, most Directors underscored the importance of wage moderation and differentiation by reducing wage indexation, combined with reforms to bolster labor flexibility, employment, and competitiveness.

Directors praised the timely banking assistance and strong supervisory and regulatory policies, including dynamic loan-loss provisions, which have helped banks weather the crisis well. Nevertheless, the challenge remains to assist banks through the very difficult operating environment, and to curtail the excessive reliance on wholesale funding. Directors welcomed the design of the liquidity and funding assistance to banks, with appropriate sunset clauses and pricing, and enhanced deposit insurance, as agreed with EU partners.

Directors expected that deteriorating asset quality and higher capitalization demanded by markets would continue to weigh on the outlook, and increase the likelihood of consolidation in the banking system. They welcomed the authorities' readiness to act as necessary, focusing on market-based solutions to the extent possible, complemented with the provision of capital if needed to forestall eventual systemic pressures.

Directors noted that the vulnerability of the savings banks, stemming from their dependence on local real estate activity, calls for close monitoring. They welcomed the increased acceptance of interregional mergers, and considered that greater use of participating capital shares, as conditions permit, would bolster balance sheets. Directors welcomed the continued strong resilience of Spain's two largest banks, while stressing that tight cross-border cooperation with EU, U.S., and Latin American supervisors will remain crucial in these testing times.

Public Information Notices (PINs) form part of the IMF's efforts to promote transparency of the IMF's views and analysis of economic developments and policies. With the consent of the country (or countries) concerned, PINs are issued after Executive Board discussions of Article IV consultations with member countries, of its surveillance of developments at the regional level, of post-program monitoring, and of ex post assessments of member countries with longer-term program engagements. PINs are also issued after Executive Board discussions of general policy matters, unless otherwise decided by the Executive Board in a particular case. The staff report (use the free Adobe Acrobat Reader to view this pdf file) for the 2008 Article IV Consultation with Spain is also available. 
Spain: Selected Economic Indicators, 2004-08

\begin{tabular}{|c|c|c|c|c|c|}
\hline & 2004 & 2005 & 2006 & 2007 & 2008 \\
\hline \multicolumn{6}{|l|}{ Real economy (change in percent) } \\
\hline Real GDP & 3.3 & 3.6 & 3.9 & 3.7 & 1.2 \\
\hline Domestic demand & 4.8 & 5.1 & 5.1 & 4.2 & 0.2 \\
\hline HICP (average) & 3.1 & 3.4 & 3.6 & 2.8 & 4.1 \\
\hline Unemployment rate (in percent) & 11.0 & 9.2 & 8.5 & 8.3 & 11.3 \\
\hline \multicolumn{6}{|c|}{$\begin{array}{l}\text { Public finance (general government; in percent of } \\
\text { GDP) }\end{array}$} \\
\hline Overall balance & -0.3 & 1.0 & 2.0 & 2.2 & -3.8 \\
\hline Primary balance & 1.7 & 2.8 & 3.7 & 3.8 & -2.3 \\
\hline \multicolumn{6}{|l|}{ Interest rates } \\
\hline Money market rate & 2.1 & 2.2 & 3.1 & 3.8 & 4.6 \\
\hline Government bond yield & 4.1 & 3.4 & 3.8 & 4.4 & 5.3 \\
\hline \multicolumn{6}{|l|}{ Balance of payments (in percent of GDP) } \\
\hline Trade balance & -3.8 & -5.1 & -6.2 & -6.4 & -5.6 \\
\hline Current account & -5.3 & -7.4 & -8.9 & -10.1 & -9.6 \\
\hline \multicolumn{6}{|l|}{ Fund position (as of January 31,2009 ) } \\
\hline Holdings of currency (in percent of quota) & & & & & 86.2 \\
\hline Holdings of SDRs (in percent of allocation) & & & & & 49.7 \\
\hline Quota (in millions of SDR) & & & & & $3,048.9$ \\
\hline \multicolumn{6}{|l|}{ Exchange rate } \\
\hline Exchange rate regime & \multirow{2}{*}{\multicolumn{4}{|c|}{$\begin{array}{l}\text { Euro Area Member } \\
\text { US\$1.2938 per euro }\end{array}$}} & \\
\hline Present rate (February 11,2009 ) & & & & & \\
\hline Nominal effective rate $(2000=100)$ & 106.5 & 106.3 & 106.5 & 108.1 & 110.5 \\
\hline Real effective rate $(2000=100)$ & 115.5 & 119.0 & 120.5 & 124.0 & 129.8 \\
\hline
\end{tabular}

